Portland State University

PDXScholar

5-2005

\title{
Forest Resource Use, Land-Use, and Ecotourism in the Río Plátano Biosphere Reserve, Honduras
}

Christina Marie Friedle

Portland State University

Follow this and additional works at: https://pdxscholar.library.pdx.edu/open_access_etds

Part of the Human Geography Commons, and the Physical and Environmental Geography Commons Let us know how access to this document benefits you.

Recommended Citation

Friedle, Christina Marie, "Forest Resource Use, Land-Use, and Ecotourism in the Río Plátano Biosphere Reserve, Honduras" (2005). Dissertations and Theses. Paper 2228.

https://doi.org/10.15760/etd.2225

This Thesis is brought to you for free and open access. It has been accepted for inclusion in Dissertations and Theses by an authorized administrator of PDXScholar. Please contact us if we can make this document more accessible: pdxscholar@pdx.edu. 


\section{THESIS APPROVAL}

The abstract and thesis of Christina Marie Friedle for the Master of Science in

Geography were presented May 25, 2005 and accepted by the thesis committee and the department.

COMMITTEE APPROVALS:

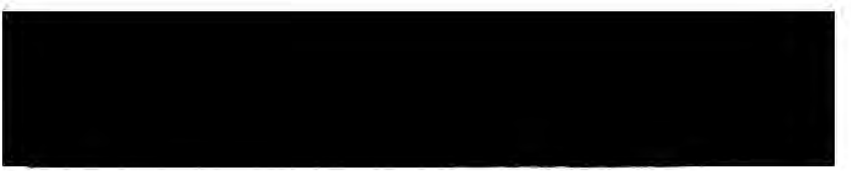

Martha A. Works, Chair

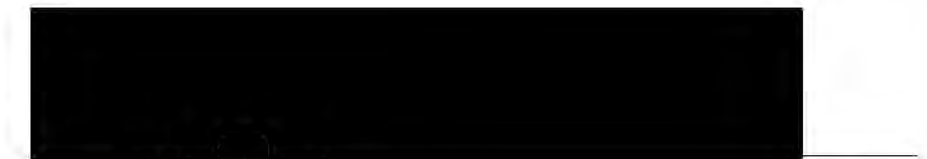

Barbara A. Brower

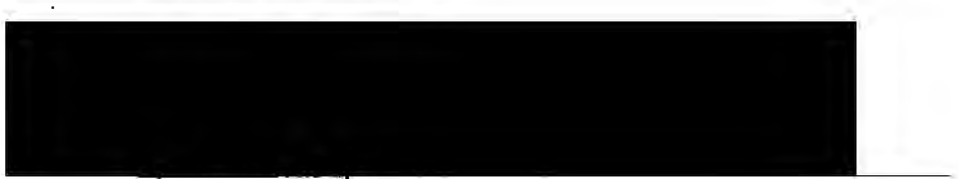

CraigS. Revels
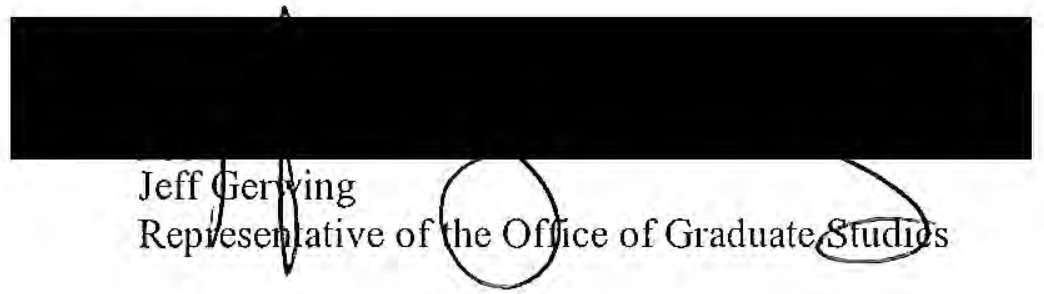

DEPARTMENT APPROVAL:

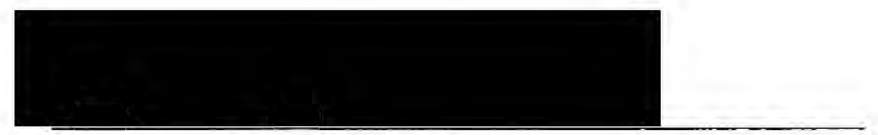

Teresa L. Bulman, Chair

Departmcnt of Geography 


\begin{abstract}
An abstract of the thesis of Christina Marie Friedle for the Master of Science degree in Geography presented May 25, 2005.
\end{abstract}

Title: Forest Resource Use, Land-Use, and Ecotourism in the Rio Platano Biosphere Reserve, Honduras

The Río Plátano Biosphere Reserve, a tropical rainforest reserve in the northeastern comer of Honduras, is home to several stbsistence-based indigenous groups, including the Miskito, Pech and Garifuna, as well as the non-indigenous Ladinos. Communities within the reserve depend on forest resources, swidden agriculture, marine resources and/or small-scale ranching as the foundations for local economies. Regulations placed on these subsistence practices, after establishment of the biosphere reserve in 1980 , have created unique and new pressures and resulted in a blend of traditional and innovative resource use. A notable result is the promotion of ecotourism as a solution for meeting the economic needs of local populations while conserving local resources. This thesis documents current resource use in the Miskito and Ladino communities of Banaka, Brans, and Fuente de Jacob, in the Río Plátano 
Biosphere Reserve and the potential of ecotourism to maintain both local economies and consumption of tropical rainforest resources in these communities. Analysis suggests that a community-based approach to ecotourism can result in economic benefits and maintain local culture. This thesis documents current resource use (agricultural crops and trees, gathered and cultivated plants, tree-use, and hunting), resident perspectives on ecotourism development and industry, and provides the foundation for long-term monitoring and analysis on the effects of ecotourism on forest resource and land-use in the greater Banaka region. 


\title{
FOREST RESOURCE USE, LAND-USE, AND ECOTOURISM IN THE RÍO PLÁTANO BIOSPHERE RESERVE, HONDURAS
}

\author{
by \\ CHRISTINA MARIE FRIEDLE
}

A thesis submitted in partial fulfillment of the requirements for the degree of

\section{MASTER OF SCIENCE in GEOGRAPHY}

Portland State University 2005 


\section{ACKNOWLEDGEMENTS}

Without the help from the people at Portland State University, those who live and work in the Río Plátano Biosphere Reserve and my family, this project would not have been possible. I would like to start by giving iny sincere thanks to Martha Works, my advisor, for her patience, advice and support. Her guidance throughout this challenging process was tremendous. Thank you also to Barbara Brower, Craig Revels, and Jeff Gerwing for providing your academic and personal feedback and assistance during my time in the master's program. Carolyn Perry and Angelica Nelson, thanks for always offering your support and assistance! Moreover, the rewards granted to me by the William and Edith Rockie and Price Scholarships, and my graduate assistantship with the Oregon Geographic Alliance provided necessary financial support to achieve this foreign-based fieldwork.

A sincere thank you to Lupario Martines of Banaka. Lupario made my research in Banaka, Brans and Fuente de Jacob possible. The support and cooperation of Lupario, Luila, Hani, Celso, Alex, their families and the entire conmunity of Banaka, was essential to the completion of this thesis. They all made our stay in their community comfortable and were exceptionally generous. The cooperation of each individual that participated in my research has been greatly appreciated. Additionally there were all those people who assisted in the process of getting to conduct research 
in the reserve and introducing me to the community of Banaka. Thank you Carlos Molinero, Osvaldo Munguia and all the people at MOPAWI; Steve and Jude Collins from Tear Fund; Dr. Cyril Nelson and Sergio Martínez Molina at UNAH; Arless Ponce and Emilio Aguilar at IHAH; Donaldo and Christina Allen in Belen; and Elma and Eddie Bodden in Rais Tá.

A special thanks to Peter Herlilky and Ratna Radhakrishna for provoking my interest in this area and helping with both the preparations to the Río Plátano Biosphere Reserve and getting information for my thesis writing. Additionally, thank you Erik Nielson for assistance with getting ecotourism information from the reserve.

And most of all, I have to thank Ben for not only being my research assistant, but for providing a slew of mental, emotional and physical support throughout my academic career and life.

Thanks to all my friends and family who supported me. 


\section{TABLE OF CONTENTS}

\section{PAGE}

ACKNOWLEDGEMENTS $\mathrm{i}$

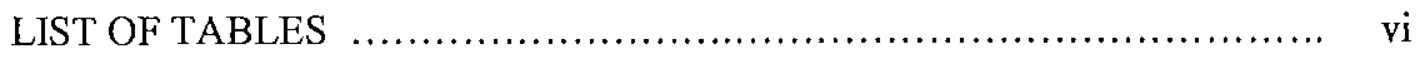

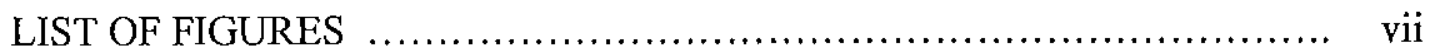

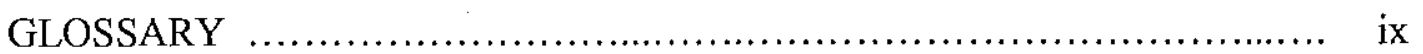

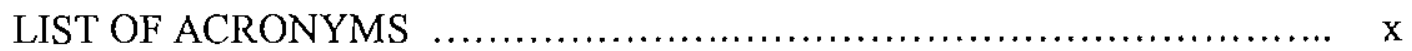

\section{CHAPTER}

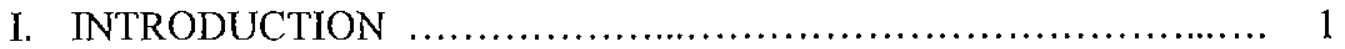

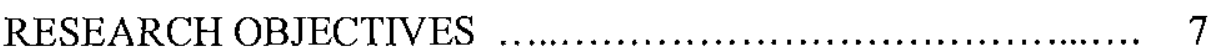

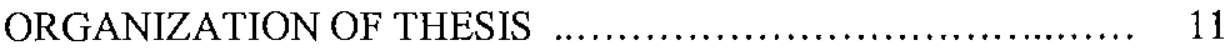

II. LITERATURE REVIEW ........................................ 12

PROTECTED AREAS AND CONSERVATION $\ldots \ldots \ldots \ldots \ldots \ldots \ldots . . . . . . .13$

UNESCO AND MAN AND BIOSPHERE PROGRAM $\ldots \ldots \ldots \ldots \ldots . . \ldots 21$

NATURAL RESOURCE MANAGEMENT AND LAND-USE .... 26

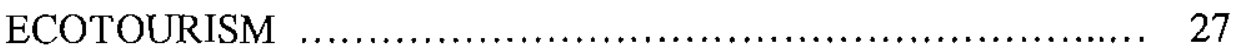

III. LA MOSQUITIA AND THE RÍO PLÁTANO BIOSPHERE

RESERVE ..................................................... 32

RÍO PLÁTANO BIOSPHERE RESERVE ...................................... 34

a) Creation of the Reserve

b) Flora and Fauna 
c) Physical Features

d) Archeological Resources

e) Ethuic Groups

f) Reserve Management

g) Land Rights

h) Research Communities: Banaka, Brans and Fuente de Jacob

IV. METHODOLOGY $\ldots \ldots \ldots \ldots \ldots \ldots \ldots \ldots \ldots \ldots \ldots \ldots \ldots \ldots \ldots \ldots \ldots, 53$

HOUSEHOLD SURVEYS/FORMAL INTERVIEW $\ldots \ldots \ldots \ldots \ldots \ldots, 55$

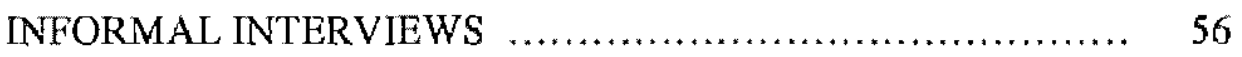

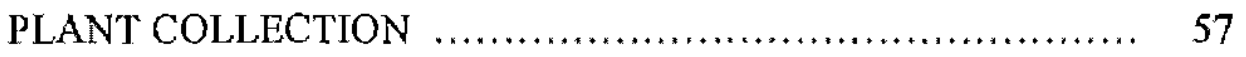

PARTICIPANT OBSERVATION $\ldots \ldots \ldots \ldots \ldots \ldots \ldots \ldots \ldots \ldots \ldots, 58$

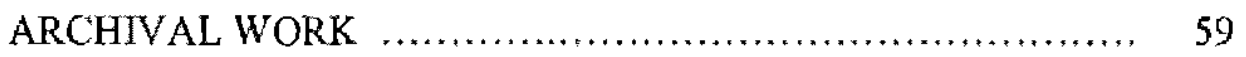

DESCRIPTION OF RESEARCH PARTICIPANTS $\ldots \ldots \ldots \ldots \ldots \ldots . \ldots 9$

V. FOREST RESOURCE MANAGEMENT $\ldots \ldots \ldots \ldots \ldots \ldots \ldots \ldots \ldots \ldots . \ldots 2 b$

GATHERED PLANT-USE $\ldots \ldots \ldots \ldots \ldots \ldots \ldots \ldots \ldots \ldots \ldots \ldots \ldots, 63$

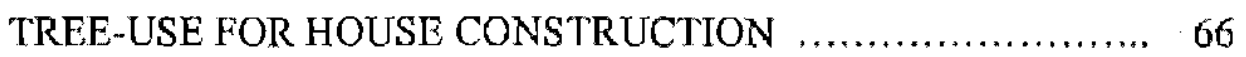

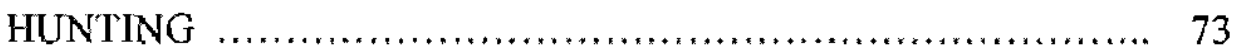

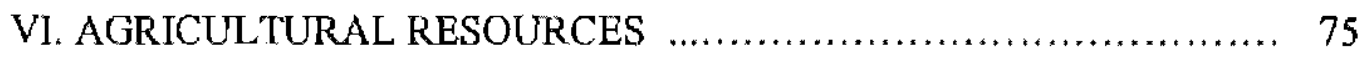

CULTIVATED MEDICINAL AND CULINARY PLANTS ....... 75

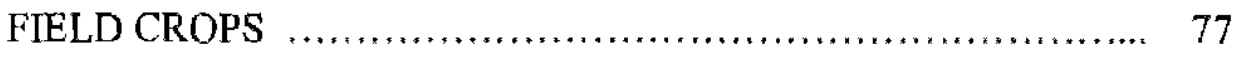

CHARACTERISTICS OF AGRICULTURAL PLOTS ........... 81

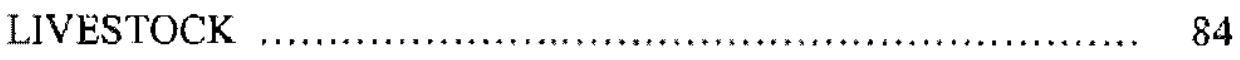

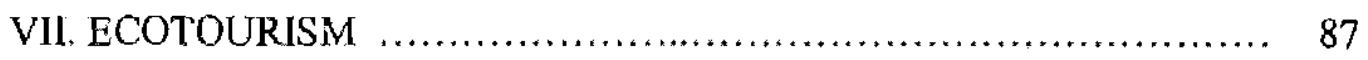

ECOTOURISM IN THE RÍO PLATAANO BIOSPHERE

RESERVE ............................................ 88

ECOTOURISM DEMAND $\ldots \ldots \ldots \ldots \ldots \ldots \ldots \ldots \ldots \ldots \ldots \ldots, \ldots 1$ 
ECOTOURISM POTENTIAL AND RESIDENT

PERSPECTIVES

VIII. DISCUSSION AND CONCLUDING REMARKS

OVERVIEW ON FOREST RESOURCE USE 103

COMMUNITY COMPARISONS ON RESOURCE USE

GENDER COMPARISONS ON RESOURCE USE

INFLUENCE OF OUTSIDE SOURCES OF INCOME

ON RESOURCE USE

RESIDENT PERSPECTIVE ON PARK MANAGEMENT

CONCLUDING REMARKS

REFERENCES CITED 120

APPENDIX A: Formal Interview Questionnaire 128

APPENDIX B: Ecotourism Committee Notes

APPENDIX C: Plant and Tree List - Spanish, English and Scientific Names

APPENDIX D: Agricultural Crop List - Spanish,

English and Scientific Names 136

APPENDIX E: Las Marias Ecotourism Regulations 138

APPENDIX F: Banaka's Request for MOPAWI Funding 145 


\section{LIST OF TABLES}

1. IUCN's Protected Area Categories ............................. 15

2. Characteristics of Current Knowledge Systems Applied to Natural Resource Management .................................. 20

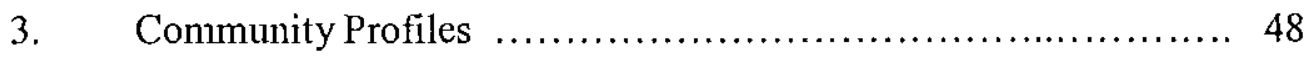

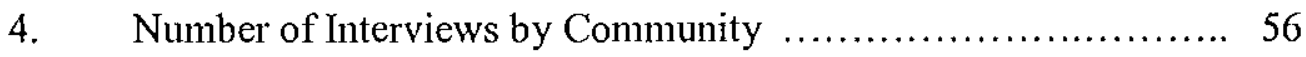

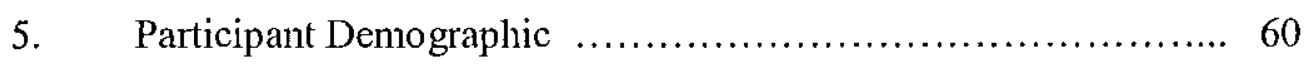

6. Ethnic Diversity of Research Participants ..................... 60

7. Number of Households That Occupy a Second Residence ......... 61

8. Uses of Commonly Gathered Plants ............................ 64

9. Trees Commonly Used for House Construction ................. 67

10. Cultivated Culinary and Medicinal Plants _.................... 76

11. Plants Cultivated in Survey Respondents Gardens or

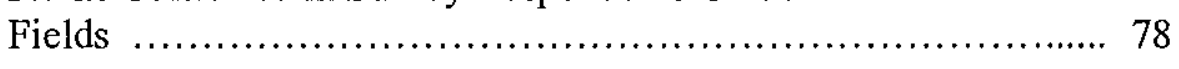

12. Agricultural Field Size as Reported by Residents ............. 82

13. Average Number of Household Animals, by Ethnicity ........... 85

14. Average Number of Household Animals, by Community ........ 85

15. Plant Use in the Banaka Region, by Ethnicity ................. 104

16. Tree Use for House Construction, by Ethnicity $\ldots \ldots \ldots \ldots \ldots \ldots . .106$

17. Resident Perspectives on Park Management ................... 113 


\section{LIST OF FIGURES}

FIGURE

PAGE

1. Río Plátano Biosphere Reserve, Honduras f.................... 3

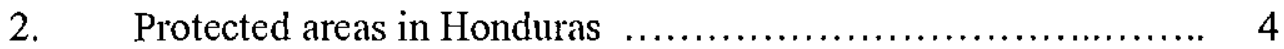

3. La Mosquitia, Honduras and Nicaragua $\ldots \ldots \ldots \ldots \ldots \ldots \ldots . \ldots$

4. Zones of the Río Plátano Biosphere Reserve f.................. 23

5. Road development into the Río Plátano Biosphere

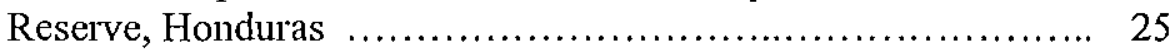

6. Biosphere Reserves in La Mosquitia ....................... 33

7. Río Plátano Biosphere Reserve, Honduras .................... 35

8. Caribbean Coast of the Río Plátano Biosphere Reserve, Honduras $\ldots \ldots \ldots \ldots \ldots \ldots \ldots \ldots \ldots \ldots \ldots \ldots \ldots \ldots \ldots \ldots \ldots, 40$

9. Traditional Miskito champa ............................ 49

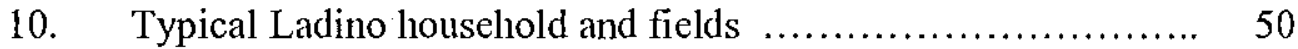

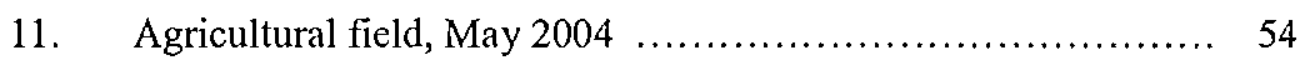

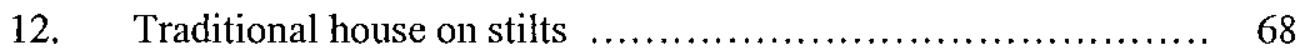

13. Separation of sleeping quarters and kitchen f................ 69

14. Traditional Calptrogyne sarapiquensis roof ................. 71

15. Roofing materials used in the research area $\ldots \ldots \ldots \ldots \ldots \ldots . . . \ldots . \ldots 1$

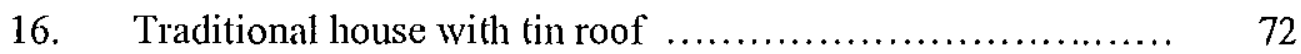

17. Sampopos on Manihot spp. ............................. 80

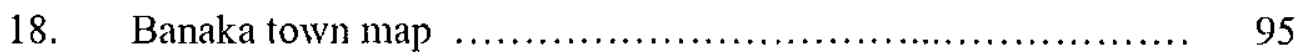


19. Banaka ecotourism destination, petrogylphs ................. 97

20. Banaka ecotourism destination, El Mirador .................. 97

21. Banaka ecotourism hospedaje ............................ 98

22. Banaka ecotourism hospedaje ............................ 98 


\section{GLOSSARY}

Abajo: Below, downstrcam

Adentro: Inside, in the interior region of the community

Arriba: Above, upstream

Buzos: Lobster divers

Cayuceros: Canoemen for the lobster industry

Champas: Temporary or seasonal house

Comarcas: Indian Homelands with semi-sutonomous political organizations with jurisdiction under the national government.

Comedor: Locally run restaurant

Comite Vigilante: Vigilance committee

Guamile: Fallowing or second growth forest

Guineos: General term used to describe all varieties of bananas

Hospedaje: Locally run ecotourism lodge

Sampopos: Leaf culter ants

Solares: Small garden in close proximity to a house.

Wabul: Traditional Miskito drink made of mashed sweet bananas and coconut milk. 


\section{LIST OF ACRONYMS}

AFE/COHDEFOR Administración Forestal del Estado Corporación Hondureña de Desarollo Forestal (Río Plátano Forestry Region Department)

BRP

Biosfera Rio Plátano (Project initiated for the management and protection of the RPBR)

COHDEFOR Corporación Hondureña de Desarollo Forestal (Honduran Forest Development Corp)

DAPVS

Departamento de Areas Protegidas y Vida Silvestre (Department of Protected Areas and Wildlife)

GFA

Gesellschaft fïr Agrrarprojekte (German banking group)

ICDP

Integrated Conservation and Development Prograin

IGBP

International Geosphere-Biosphere Programme

IHDP

International Human Dimensions Programme

IPZ

Investigación Participativa de Subzonificación (Participatory Zonification Investigation)

IUCN

International Union for Conservation of Nature

KfW

Kreditanstalt fiir Wiederaufbau (German banking group)

LUCC

Land Use/Cover Change

$\mathrm{MAB}$

Man and Biosphere Program

MASTA

Mosquitia Asla Takanka (Unity of La Mosquitia)

MOPAWI

Mosquitia Pawisa Apiska (NGO in the RPBR meaning, Development of Mosquitia)

NGO

Non-Governmental Organization 
PROARCA

PZM

RENARE

RPBR

TRAMIL

UNAH

UNESCO

USAID
Programa Ambeinte Regional de Centroamericana (Regional Environmental Program for Central America, a USAID funded program)

Participatory Zoning and Management

Recursos Naturales Renovables (Department of Renewable Natural Resources)

Río Plátano Biosphere Reserve

Investigación Aplicada y Difusión del Uso de Plantas Medicinales en el Caribe (Applied Research and Diffusion of Medicinal Plant Use in the Caribbean)

Universidad Nacional Autónoma de Honduras (National Autonomous University of Honduras)

United Nations Educational, Scientific, and Cultural Organization

United State Agency for Intemational Development 


\section{CHAPTER ONE}

\section{INTRODUCTION}

Tropical rainforests with their array of natural resources and biodiversity have been the focus of conservation efforts for the last twenty to thirty years, resulting in an increased number of protected areas worldwide. The emphasis on biodiversity conservation in rainforests often ignores the human element and the dependence of indigenous people and societies on the physical environment for their livelihood. Protecting areas with high biodiversity, by isolating them from human influence, creates a conflict for indigenous societies. In indigenous, subsistence-based societies, the physical environment shapes natural resource and land-use. Peoples' existence depends on the availability of surrounding forest resources. Herbs, spices, food, water and fuel are all collected daily. Regulations placed on these societies create unique and new pressures resulting in a blending of traditional and modern resource use. This tension has led to the introduction of new conservation models, including a biosphere reserve model, which accommodates indigenous communities and acknowledges their role in the conservation and sustainability of tropical rainforests.

The purpose of this thesis is to identify factors influencing forest resource use in several subsistent agricultural communities and the potential for ecotourism 
development within the cultural zone of the Río Plátano Biosphere Reserve (RPBR) in Honduras, Central America (Figure 1). One of the communities, Banaka, is establishing small-scale ecotourism as a way to support biodiversity conservation and create economic opportunities within a protected tropical rainforest. Banaka, still in the early stages of this transition, demonstrates how small communities can adapt to changing economic and regulatory circumstances.

In Honduras fifteen principal National Parks, four Wildlife Refuges, two Biological Reserves, and two Biosphere Reserves protect an estimated two million hectares of forest. The Río Plátano and Tawalka-Asangni Biosphere Reserves are both located in the Honduran Mosquitia, which is the most remote area of Honduras and equals approximately twenty percent of the nation's land. They encompass sections of the Gracias a Dios, Colon and Olancho departments (departments are similar to states) in the northeastern region of the country on the Caribbean coast (Figure 2). A majority of the intact primary forests in Honduras is found in the Mosquitia region.

The Río Plátano Biosphere Reserve was established in 1980 in accordance with the United Nations Educational, Scientific, and Cultural Organization (UNESCO) Man and the Biosphere Prograin (MAB) and expanded in 1997 to encompass 800,000 hectares. Biosphere Reserves are internationally recognized and created with the purpose of establishing a balance between conserving cultures and biodiversity, and maintaining a sustainable use of the land. 


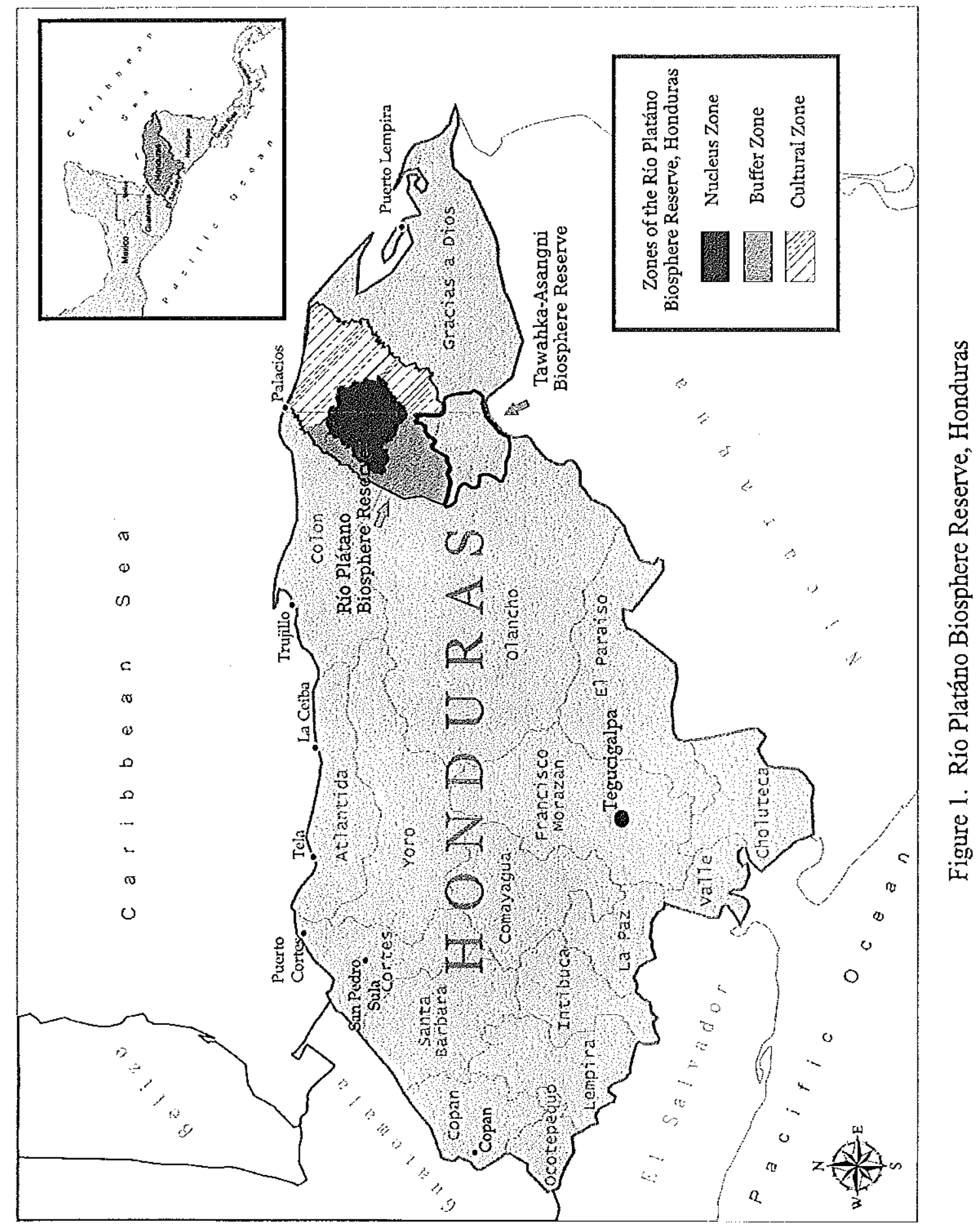




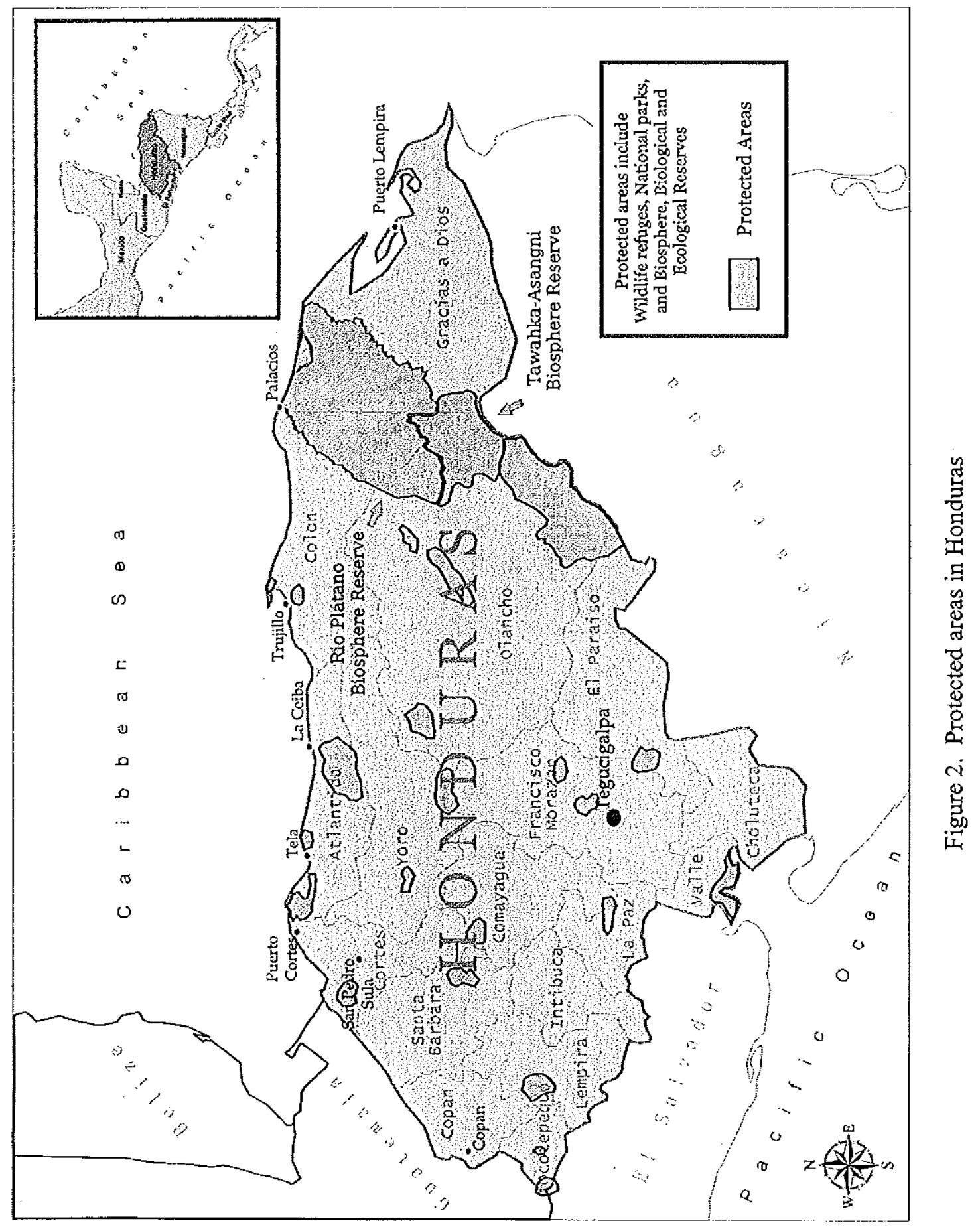


Since 1980 a series of management plans for the RPBR has been established and revised to keep up with the evolving conditions of the physical and cultural environment. My research and the greater part of this thesis is focused on current forest resource and land-use practices - and the emerging ecotourism industry - in several communities located within the inland tropical rainforest of the Río Plátano Biosphere Reserve in Honduras. In an evaluation of ecotourism theory and practice, Ross and Wall (1999) identify methods to assess and monitor the impacts of ecotourism. They emphasize the significance of fostering positive links between people, natural resources, biodiversity and ecotourism and using the examination of those relationships as a starting point to evaluate an ecotourism site through the use of relevant indicators, such as livelihood strategies and local uses of protected areas. The examination of forest resource and land-use within the indigenous Miskito community of Banaka and two Ladino (non-indigenous Honduran) communities of Brans and Fuente de Jacob contributes information for future assessment on the change of resource use with the introduction of ecotourisn. Management in the reserve aims to conserve both biodiversity and culture, and thus this research includes the examination of forest resource uses and land-use including lumber, gathered and cultivated plants, agricultural crops, livestock, and the role of the emerging ecotourism iudustry as a catalyst for conservation and sustainable development.

This thesis employs both physical and social geographic perspectives in an investigation of the intricate relationship between humans and their forest resource and land-uses. Not only does the physical environment shape access and control over 
forest resources, but so do the political and cultural narratives that give them form and meaning (Zimmerer and Basset 2003; 3). The examination of indigenous forest resource and land-use has been a subject of research for many scholars in geography, ecology, biology, agriculture, and anthropology. Anthropologist David Dodds (1987) identifies five key reasons for studying indigenous land-use: 1) outside contact typically results in land loss to commercial uses and thus the loss of knowledge about natural resources, 2) land and natural resources are the foundation for maintaining indigenous culture, 3) there are humanitarian concerns for the right to continue an established way of life, 4) once indigenous peoples are deprived of land rights and control over natural resources, it can lead to greater social problems (i.e. Ainerican, Brazilian and Mexican Indians), and 5) it contributes to scientific understanding, resource management, and alternative ways of relating to the environment.

Protected areas and conservation also receive attention in the geographical and ecological literature on forest resource use, land-use and ecotourism. More specifically, gcographers have been examining the effects of defined conservation areas and access and control of natural resources within those areas (Zimmerer 2000; Zimmerer and Bassett 2003). Bernard Neitsclimann (1973; 1997) and Peter Herlihy (1990; 1993; 1997) have researched indigenous Miskito coinmunities in La Mosquitia of Honduras and Nicaragua and the challenges of empowerment and participation in the management of natural resources. Additionally, geographers and other scientists have examined the use of ecotourism as a viable model for natural resource and biodiversity conservation (Young 1999; Honey 1999; Stem et al 2003; Nielsen and 
Munguia 1998; King and Stewart 1996; Wall 1997; Farrell and Marion 200; Sundberg 1998; Bonta 2003). In the Río Plátano Biosphere Reserve, Nielson et al. (2003) found that community-based ecotourism can increase biodiversity conservation and can provide an effective means for building local constituencies of conservationists.

The research conducted on protected areas is significant because they have been designated areas of environmental importance for their unique or disappearing natural features; they therefore require inanagement. The development of park models benefits from studies that help evaluate whether management goals are appropriate and effective. Since the biosphere reserve model aims to maintain a balance between biodiversity and cultural conservation, analysis and documentation of humanenvironmental interaction in biosphere reserves is necessary to further our understanding of how to best strike this balance.

This thesis approaches the topic from a geographical perspective, emphasizing place and interactions between humans and physical environment. This thesis also examines forest resource and land-use by exploring how politics and culture influence resource use at a local level.

\section{Research Objectives}

The Mosquitia, a tropical area in eastern Honduras and northeastern Nicaragua (Figure 3), forms the largest contiguous tract of rainforest remaining in Central America (Herlihy 1999; 107). This region, still isolated from many modern developments, contains valuable ecological and cultural resources. The Río Plátano 


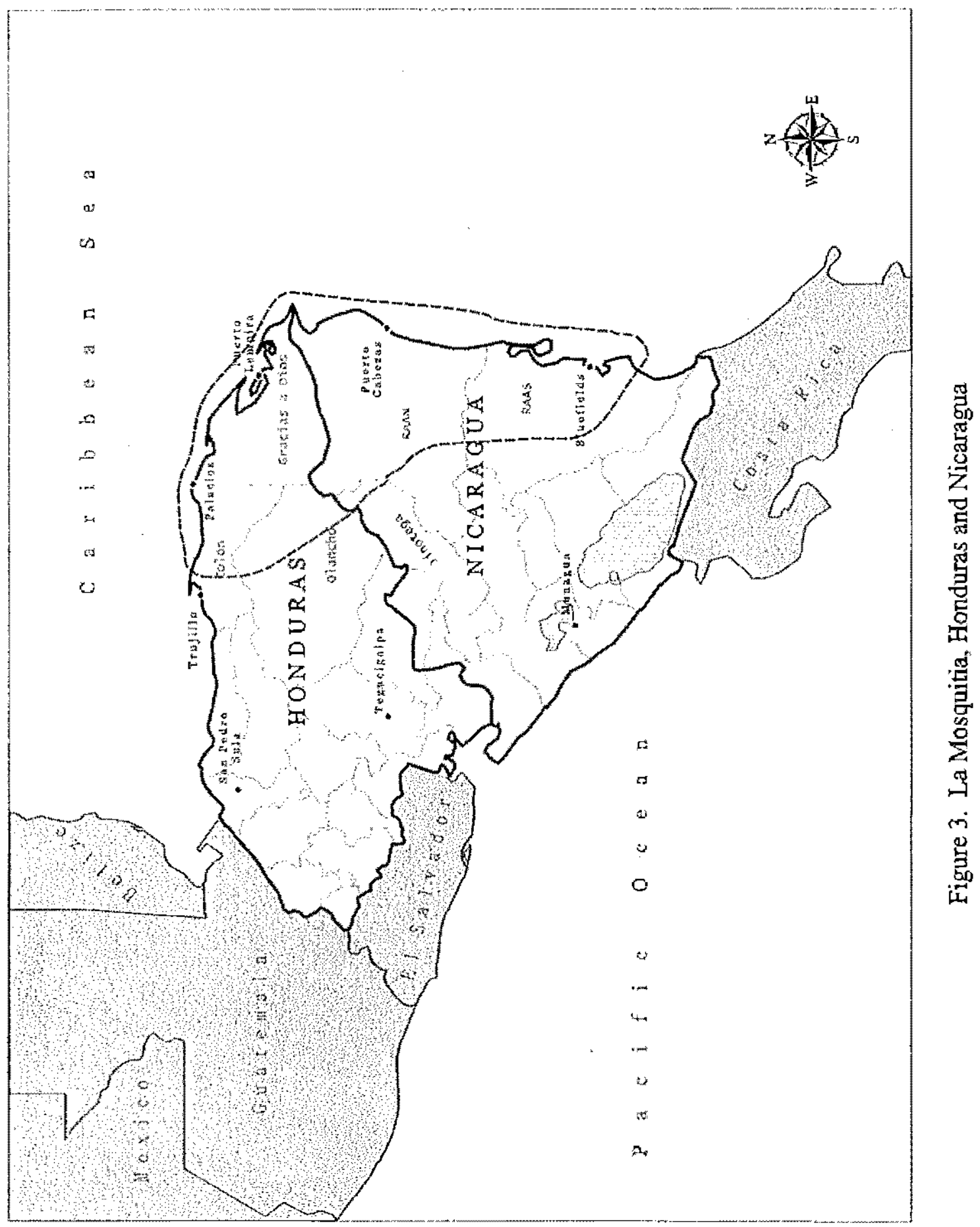


and Tawahka-Asangni Biosphere Reserves were created (in 1980 and 1999, respectively) as an effort to protect those valuable resources, while at the same time protecting the indigenous populations and the land that has sustained them. Increasing population and colonization of the Mosquitia have influenced farming practices, as well as the forest resource and land-use practices of the reserve residents. To ensure protection of the biological and cultural resources of the region it is necessary for reserve management to adopt policies to meet with the changing situation. This requires detailed data concerning the cultural ecology of indigenous people, long-term monitoring of species, regulation of existing species, natural resource uses, and landuse of indigenous peoples (Froehlich and Schwerin 1983; 3).

Banaka and its surrounding areas were chosen as the research area because it is representative of other towns in the reserve, therefore suggesting that forest resource and land-use would be similar in other comparable communities. The research area is representative and was chosen because of the following key characteristics: (1) The RPBR Plan de Manejo (AFE-COHDEFOR et al. 2000) specifically states that the intention of reserve management is to remain flexible and contimually improve the plan based on periodic evaluation. With a steady increase in outside influences on forest resource use, examining the resource and land-use practices of Banaka and surrounding towns will contribute current information for management evaluation and modification; (2) The research area is representative of agricultural towns in the cultural zone of the reserve. Conducting research in this area contributes to information about both Miskito and Ladino land-use practices within the reserve's 
agricultural interior. Banaka is mostly Miskito and is surrounded by Ladino settlements that rely on Banaka as a commerce center. This spatial arrangement of ethnic communities is common within the reserve; Miskito towns are typically centralized, while Ladino towns tend to be spread out and decentralized; (3) Banaka is following a path taken by other towns in the reserve by establishing an ecotourism industry as an alternative source of income and to further the goals of biodiversity conservation in the reserve; and (4) Focus on a localized area such as Banaka allows examination of how multiple layers of policies influence a specific community. This thesis contributes to understanding forest resource and land-use within a protected tropical rain forest through analysis of agricultural practices, forest resouree extraction, conservation efforts, and ecotourism. The objectives of the study are to:

- Identify forest resource, land- use, and conservation practices in communities within the agricultural areas of the reserve.

- Compare forest resource and land-use between Miskito and Ladino conmmunities.

- Analyze factors influencing resource extraction and conservation practices.

- Examine the role of ecotourism in conservation efforts and economic development.

The goals of this research are to contribute to understanding the larger context of forest resource management and land-use change in the tropics and the role of ecotourism in conservation of protected areas, through analysis of a study site in the Mosquitia. There are strong influences from international, national and local 
organizations to establish community-based ecotourism as a method for empowerment over resource management. This research is the first to conduct an in-depth analysis of Banaka in the preliminary stages of the ecotourism establishment process and provides a base for future investigations concerning the ecological, cultural, biological and social impacts of ecotourism in the region.

\section{Organization of Thesis}

This thesis is organized to document and examine forest resource and land-use of a town within a protected area attempting to establish a community-based ecotourism industry. The use of ecotourism as a conservation and economic tool is relatively new and this research contributes to future analysis on conservation practices and forest resource dependencies resulting from ecotourism development.

The following chapter reviews the multi-disciplinary literature on which this thesis is based. Chapter Three examines the physical, cultural, and political environment of the Mosquitia of Honduras, the Río Plátano Biosphere Reserve, and the greater Banaka area. Chapter Four outlines the methodology used in this research and includes a description of the participants of the study. Chapter Five presents the results of my research on forest resource use, including gathered plant-use, tree-use for house construction, hunting and fishing. Chapter Six presents the results and findings of my research on cultivated plants, agricultural crops and livestock. An analysis of ecotourism and its role in the research area is found in Chapter Seven. Finally, Chapter Eight presents a discussion of the results and concluding remarks. 


\section{CHAPTER TWO}

\section{LITERATURE REVIEW}

This thesis focuses on the issue of social-envirommental interactions within an internationally recognized protected area. Controversy surrounds the issue of human prescnce in protected areas containing valuable natural resources around the world. Approximately $75 \%$ of Central America's protected areas include lands occupied or used by indigenous peoples (Herlihy 1997; 101). While some tropical biologists argue that human presence is incompatible with effective conservation (Schwartzman et al. $2000 ; 1352$ ), the inclusion of humans into a conceptual model of nature is increasingly accepted by conservationists and environmentalists (Naughton-Treves $2002 ; 488)$.

Protected areas throughout Central America have resulted in several management approaches, having some aspects of intemational, national, regional, and local management. Geographer Bernard Nietschınann (1997; 213), working in the Nicaraguan Mosquitia, focuses on a bottom-up, local approach to management, emphasizing that the people using natural resources could most effectively manage and conserve natural resources. Neitschmann dravs on Blaikie and Brookfield's (1987) claim of land management: "Land management consists of applying known 
skills to land use in such ways as to minimize or repair degradation...(7)." Bonta (2003), works in the Olancho region of Honduras, and found that local people identify habitat destruction as related to the worsening economic and political conditions at the national and international lcvel. Other research shows that management conditions that exclude local communities from protected areas will often ignore social justice and quality of life of local residents (Fortwangler 2003).

This thesis dravs on literature from various disciplines, all of which have an underlying theme involving the interactions between humans and their surrounding environment. It focuses on local level interactions with the environment and how ecotourism is encouraged as an alternative land-use option within protected areas from multiple political levels.

\section{Protected Areas and Conservation}

Growing international awareness of endangered habitats and forests is propelling the expansion of protected areas worldwide. Tropical rain forests have been prime targets for conservation. There are currently sixty-seven biosphere reserves in eighteen countries; thirty-one have been established since 1990. Latin America has recently increased the number and distribution of land conservation areas. In 1980 there were 129 protected areas in Central America covering about 9\% of the region, and as of 1997, 16\% of Central America was under the World Conservation Union/International Union for Conservation of Nature (IUCN) status (Herlihy 1990; 1997). Honduras went from having only 1\% of IUCN land in 1990 to 
approximately 10\% in 2000 (Zimmerer and Carter 2002; 208). In 1990 Central America had 240 designated protected areas, protecting a total of $13.1 \%$ of the area's land. Of those areas, seventy-five included indigenous land use accounting for $85.2 \%$ of all protected areas. In Honduras, sixteen of forty-one protected areas had indigenous land use (the Río Plátano Biosphere Reserve included) and a total of $88.2 \%$ of all Honduran protected areas (Herlihy $1990 ; 32$ ). It is important that the Central American tropics are included in the MAB reserve network. They represent a zoological exchange between two adjacent continents, have rapid population growth, and have lagged behind other regions in designating protected areas for the conservation of indigenous peoples and natural resources (Froehlich and Schwerin $1983 ; 3)$

Protected areas aim to conserve biodiversity, plant and animal species, natural resources and forests. Throughout history there have been efforts by both governments and individuals to protect areas recognized as valuable (Talbot 1982; 15). Conservation of protected areas can be studied in the context of geographical and spatial design, environment and human-environmental change, development processes including economic growth, equity and globalization (Zimmerer and Carter 2002), resource inventories, or with respect to destructive exploitation and constructive exploitation (Herlihy 1990). These factors influence the orientation of different management models of protected areas. The use of protected areas for conservation purposes stems from the belief that protection will result in a reduced loss of deforestation and biodiversity (Brandon et al. 1998). This belief is also supported by 
Wilshusen et al. $(2003 ; 5)$, although they also recognize that creation and management decisions of protected areas reflect the political environment in which they are embedded, therefore they influence the outcome of conservation goals.

The evolution of protected areas and the need for a variety of management approaches stems from the realization of many national governments that traditional national park models do not meet the needs of increasing human populations, economic uncertainty, and social instability. The purpose of protecting natural areas has changed to not only include biodiversity conservation but also recreation, education, genetic resources, management, watershed protection and other goods and services (McNeely 1982; 1). These changing needs initiated the IUCN's division of protected areas into ten broad categories in 1978 (revised in 1994 to six categories), each with management objectives and criteria. All six current IUCN categories (Table 1) include the presence of human and human actions, therefore combining the

\section{TABLE 1}

IUCN Protected Area Categories (as Defined by IUCN)

\begin{tabular}{|l|l|}
\hline $\begin{array}{l}\text { I. Strict Nature } \\
\text { Reserve/Wilderness Area }\end{array}$ & $\begin{array}{l}\text { Protected area managed mainly for science of } \\
\text { wilderness protection. }\end{array}$ \\
\hline II. National Park & $\begin{array}{l}\text { Protected area managed mainly for ecosystem } \\
\text { protection and recreation }\end{array}$ \\
\hline III. Natural Monument & $\begin{array}{l}\text { Protected area managed mainly for conservation of } \\
\text { specific natural features }\end{array}$ \\
\hline $\begin{array}{l}\text { IV. Habitat/Species } \\
\text { Management Area }\end{array}$ & $\begin{array}{l}\text { Protected area managed mainly for conservation } \\
\text { through management intervention }\end{array}$ \\
\hline $\begin{array}{l}\text { V. Protected } \\
\text { Landscape/Seascape }\end{array}$ & $\begin{array}{l}\text { Protected area managed mainly for landscape/seascape } \\
\text { protection and recreation. }\end{array}$ \\
\hline $\begin{array}{l}\text { VI. Managed Resource } \\
\text { Protected Area }\end{array}$ & $\begin{array}{l}\text { Protected area managed mainly for the sustainable use } \\
\text { of natural ecosystems. }\end{array}$ \\
\hline
\end{tabular}


objectives of conservation with development.

The role of local people in protected areas varies; some people are forced off their lands or receive financial compensation for denied access to resources, while others can be excluded from establishment or management, or be integrated into "people-oriented" strategies of community-cased conservation. One recent example in which local people have been forced off a newly established protected area is in the Central Kalahari Game Reserve in Botswana. In 1997 one thousand San (an indigenous group) were relocated to settlements on non-reserve land. Prior to the official eviction of this group of people, the Botswana government enacted policies that delayed the repair of roads, building, boreholes, and drought relief feeding programs as a way to drive people off the land (Fortwangler 2003).

An example of a protected in which local people were not involved in the creation or management, although still permitted to remain in the area, is the Beni Biosphere Reserve in Bolivia. Prior to its status as a biosphere reserve, it was studied for five years by an inter-institutional team to expand knowledge of the area, formulate a management plan, and incorporate the reserve into a regional context. The team was lead by a Bolivian biologist, and comprised of members from the Bolivian Academy of Sciences, San Andres National University, Bolivian Conservation Data Center, Beni Interdisciplinary Center for Development and Center for Community Studies. Biological inventorying, vegetation maps, population surveys, and environmental education were all conducted by national and international organizations. One focus in establishing this reserve was to effectively influence and 
change how local people use resources (Campos-Dudley 1992). The role of people in this protected area is to evolve into a population that extracts resources according to the decisions of the regional and national government.

On the other hand, in Papua New Guinea, Wildlife Management Areas can only be declared at the request of the local landowner and does not affect ownership of the area in question. The regulations that restrict use and access of the land are only those that the owners themselves decide, and enforcing those regulations is a local responsibility. Requests have stemmed from local concerns of overexploitation of wildlife from people without traditional rights in the area (Carew-Reid 1990). In this case, the local people are responsible for delineating, creating a management plan, and establishing a management committee, before the declaration of the protected area can be initiated.

The role of humans in conservation areas is part of the overarching philosophical debate on the purpose and function of protected areas. One view argues that human presence is ultimately incompatible with conservation of biological diversity (Schwartzmann et al. 2000; 1352), while the opposing view supports sustainable resource use and indigenous resource management as an equitable way to preserve ecologically valuable landscapes. Those supporting the latter view argue that placing restrictions on human settlement and resource use generates resource access and consumption conflicts for sizable rural populations (Wilshusen et al. 2003; 8). A popular approach to limit conflict is community-based park and resource management; this includes involvement from local residents. The ideology to include 
local residents in conservation efforts can be traced to 1982 when the World Congress on Parks and Protected Areas began encouraging conservation approaches that included greater local participation and sustainable use of resources (Wilshusen et. al. $2003 ; 8)$. Nevertheless, conservation is still generally thought to exclude human presence and use, and to privilege nature protection and ecological concerns (Stevens $1997 ; 26)$ even though many areas that are rich in biodiversity are also home to indigenous peoples. Bernard Nietschmann made the observation:

The vast majority of the world's biological diversity is not in gene banks, zoos, national parks or protected areas. Most biological diversity is in landscapes and seascapes inhabited and used by local peoples, mostly indigenous, whose great collective accomplishment is to have conserved the great variety of remaining life forms, using culture, the most powerful and valuable human resource, to do so. $(1992 ; 7)$.

Nietschmann suggests that a spatial pattern exists and reflects a "concept of symbiotic conservation" in which "biological and cultural diversity are mutually dependent and geographically conterminous. In any region where there is cultural diversity there will also be biological diversity and vice versa. Conversely, regions of suppressed or displaced cultures usually co-exist with degraded environments" (1992; 2). Nietschmann's observations of indigenous cultures and landscapes convey the importance of including indigenous peoples in the management of natural resources within the protected areas of high biodiversity concern. Mac Chapin (2004) agrees with Nietchınann's claim, but recognizes that despite the clear connection between cultural and biological diversity, conservation groups are still reluctant to work with indigenous groups because of difficulties with communication (both language and cultural) and political systems. 
Geographer Peter Herlihy has emphasized a participatory approach in the zoning and management plans of protected area with indigenous inhabitants. The use of participatory methodologies has been supported for the past few decades as a form of ensuring that local knowledge is incorporated into conservation efforts, empowering local people over land and natural resources, and increasing the odds that locals affected by policies will support and implement those efforts (Zimmerer and Young 1998; Knapp and Herlihy 2002). Herlihy worked with residents of the Río Plátano Biosphere Reserve, COHDEFOR, GTZ, KfW and MOPAWI, as part of the Proyecto Biosfera Rio Plátano (BRP). The Participatory Zoning and Management (PZM) component of the project aimed to define a new consensual land zoning system for the reserve, which would be used as the basis for developing the Plan de Manejo (nanagement plan) for the reserve. The Plan de Manejo was established in 2000 (AFE-COHDEFOR et al.), and zoning and natural resource management was based on the resident-gathered information from the participatory zoning project.

Three main influences dictate the conservation practices in the Río Plátano Biosphere Reserve: political policies, biodiversity conservation, and implementation of a management system that utilizes local knowledge. The Río Plátano Biosphere Reserve provides an excellent case for conservation management within the context of controlled and protected indigenous land use (Froelich and Schwerin 1983; 11). Local people, and their intimate knowledge of the reserves ecology and land, as well as their acquired knowledge of conservation and related concepts, potentially could serve conservation interests through direct management of reserve lands. 
Indigenous knowledge and practices for natural rcsource managenent sometimes conflicts with the scientific and technological approaches taken by national and international groups. Billie R. DeWalt (1999) compares traditional indigenous approaches to natural resource management with the technical scientific knowledge approach (Table 2). In general, indigenous people are extremely knowledgeable about their local environment and the interconnectedness and ecology of plants, animals, and soils; they are innovative in the way they use the resources at their disposal. In the Río Plátano Biosphere Reserve, indigenous knowledge and practices are being integrated into conventional natural resources management, through projects such as the Participatory Zoning and Management. Residents of the reserve aim to balance conservation with economic viability through their subsistence swidden agricultural practices and a growing interest in establishing ecotourism, thereby drawing on their knowledge of the local area and its attractions for outsiders.

\section{TABLE 2}

Characteristics Of Current Knowledge Systenss Applied To NRM (Dewalt 1999)

\begin{tabular}{|l|l|}
\hline $\begin{array}{c}\text { Traditional Scientific Knowledge } \\
\text { Systems }\end{array}$ & $\begin{array}{c}\text { Traditional Indigenous Knowledge } \\
\text { Systems }\end{array}$ \\
\hline \multicolumn{2}{|c|}{ RESOURCE UTILIZATION CHARACTERISTICS } \\
\hline Dependent on external resources & Dependent on local resources \\
\hline High input & Low input \\
\hline Land intensive & Land extensive \\
\hline Labor saving & Labor demanding \\
\hline Market risk & Environmental risk \\
\hline Complicated technologies & Simple technologies \\
\hline Specialized adaptive strategies & Diverse adaptive strategies \\
\hline Global sources & Local sources \\
\hline
\end{tabular}


UNESCO: Man and the Biosphere

As a conservation model, UNESCO's Man and the Biosphere (MAB) program is intended to exemplify and promote a balance between humans and the environment. Biosphere reserves are internationally recognized, yet the process for inclusion into the program must be initiated and remain under the jurisdiction of the nation. The intention of a biosphere reserve is to balance biodiversity and sustainable use of land. UNESCO (2003) outlines three basic functions a biosphere reserve is intended to fulfill:

1. A conservation function - to contribute to the conservation of landscapes, ecosystems, species, and genetic variation;

2. A development function - to foster economic and human development which is socio-culturally and ecologically sustainable;

3. A logistic function - to provide support for research, monitoring education and information exchange related to local, national, and global issues of conservation and development

UNESCO promotes an "evolving and adaptive" approach towards management that must have agreement between local communities and other societies within the nation. The MAB program was established to address the issue of preservation of indigenous human cultures, while utilizing their intimate knowledge of the ecosystem to create effective management plans for the preservation of its biodiversity (Froehlich and Sehwerin 1983; 3). The Río Plátano Biosphere Reserve management plan, supported by the Honduran government, dictates that sustainable 
use and resource management be established through participation of local and regional inhlabitants and in accordance with local traditions and customs (AFECOHDEFOR et al. 2000; 78-79).

The MAB program officially began in 1970 , and included the creation of a world network of newly proteeted areas designated as "biosphere reserves." The purposes of the international network include conservation of genetic resources, baseline ecological data, and training of local people in conservation methods and necessities (Froehlieh and Schwerin 1983, 3). Biosphere Reserves were designed to propose a solution to the problem of meeting the needs of increasing populations, while at the same time conserving land that contains a rich diversity of plants and animals unique to the area. After over thirty years as an established program, there are designated biosphere reserves in over one hundred countries.

The biosphere reserve model bridges multiple IUCN categories by having a strict natural protection zone and other less strictly managed areas surrounding it. Each is broken down into three zones - nucleus, buffer, and cultural - that dictate the types of human activity and natural resource conservation in each area (Figure 4). In the Río Plátano Biosphere Reserve, the nucleus zone excludes human use and resource extraction. Scientific research and monitoring are allowed in this area, yet as of July 2004 no research station or plans for any major scientific exploration were in progress. The buffer zone of the RPBR surrounds the southern and western part of the nucleus zone and is designated for small-scale commercial agriculture and resource extraction. Experimental research, monitoring, and training are permitted in this area 


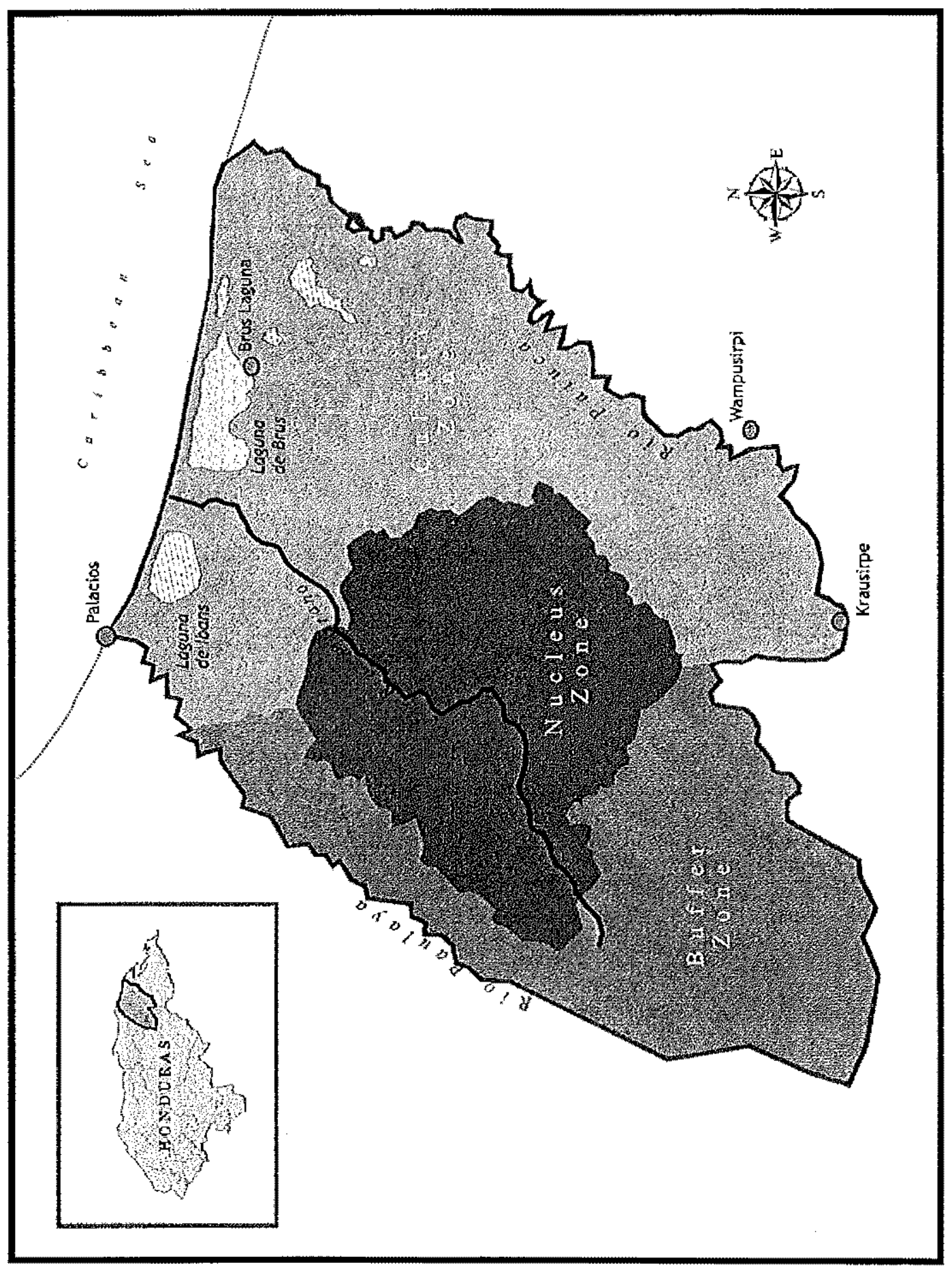

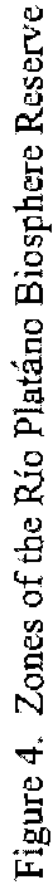


to help serve as a laboratory for land management. In the Río Plátano Biosphere Reserve, the buffer zone is the closest and most accessible area to the rest of Honduras, as a road through Olancho is rapidly approaching (Figure 5). This is creating a situation where a large number of Ladinos are entering the reserve seeking land for farming and cattle-raising.

The RPBR cultural zone surrounds the northern and eastern part of the nucleus zone and is where the majority of indigenous people reside. The cultural zone is intended to allow human settlements and to promote long-term conservation and sustainability. Comnunities within the cultural zone are responsible for working together to manage and develop the area sustainably.

To become designated as a biosphere reserve the following requirements must be met. The area must:

- Be representative of a biogeographic region, including some human intervention.

- Have landscapes, ecosystems, animal and plant species that need conservation.

- Offer opportunities to explore and demonstrate approaches to sustainable development.

- Be of appropriate size for three basic functions of biosphere reserves Have an appropriate zoning system, incorporating all three zone types (UNESCO 2003). The 5,200 square kilometer Río Plátano Biosphere Reserve was accepted into the MAB program in 1980 in accordance with the guidelines established by UNESCO, and designated a World Heritage site in 1982. 


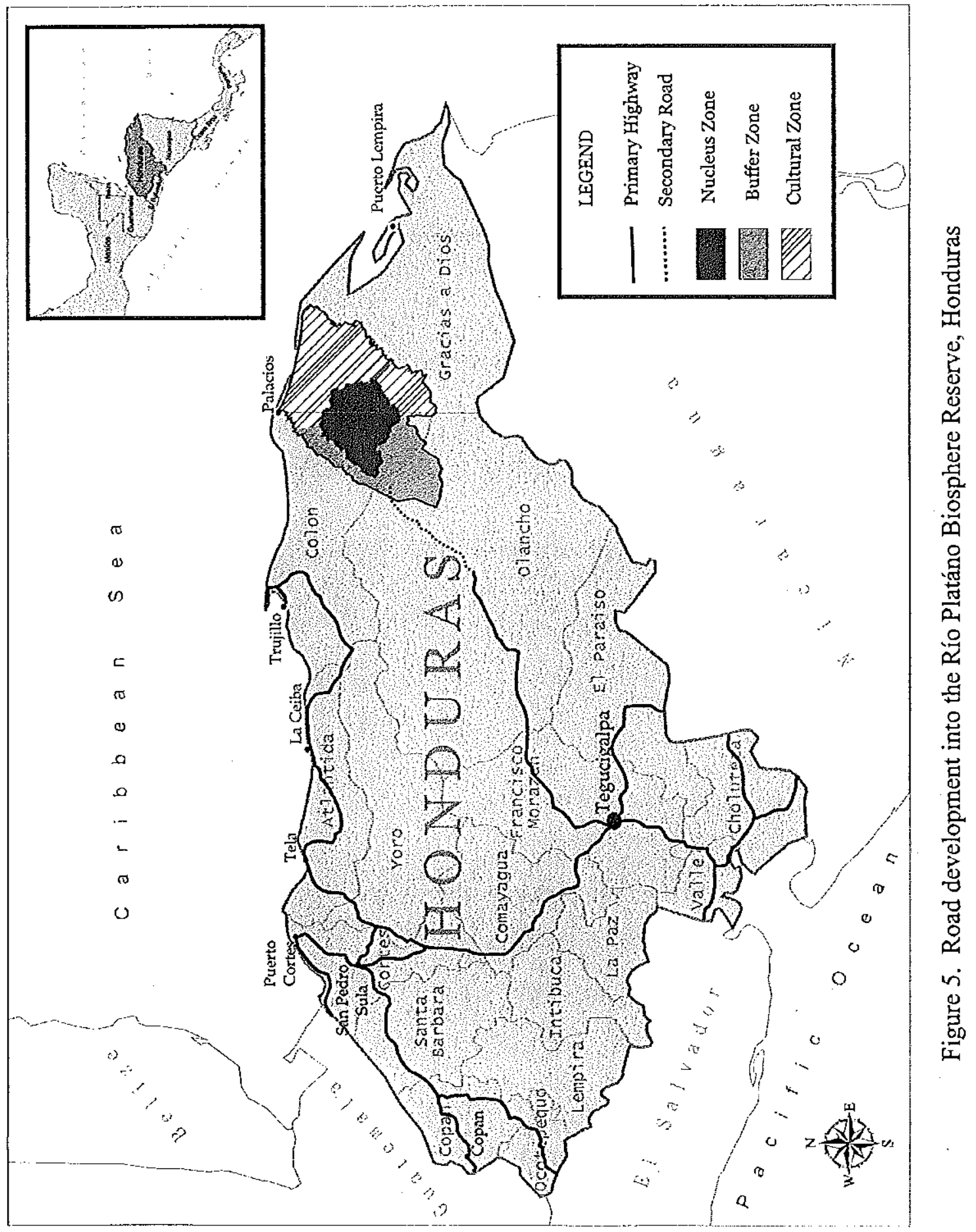




\section{Traditional Resource Management and Land-Use}

Research on conservation practices and natural resource management within protected areas of Latin America has revealed that (1) the use of swidden fallows in the tropics is an ecologically and potentially economically viable way of reducing the destruction of mature forests and providing a source of useful products for farmers (Denevan and Padoch 1988), (2) people often talk about conservation in a way that mimicked the non-governmental organizations (NGO's) working in the area in order to receive financial benefits (Sundberg 1998), and (3) ecotourism does lead to sustainable development and economic opportunities, but it does not lead people to stop practicing other exploitative activities for economic gains (Zimmerer and Carter 2002; 213). All three cases relate to the Río Plátano Biosphere Reserve in that residents use a swidden agricultural system, have a prominent NGO (MOPAWI) that vorks closely with residents on conservation and development, and is using ecotourisin to balance conservation with economic viability.

In relation to natural resource management, decisions made on how land will be used within protected areas - for ecotourism, agroforestry, or swidden agriculture is significant to the global themes of land-use/cover change (LUCC). In the early 1990's, the International Geosphere-Biosphere Progranme (IGBP) and the International Human Dimensions Progranme (IHDP) developed a research agenda to expand the understanding of patterns, processes and human responses to LUCC; to create integrated global and regional models; and to develop databases on land surfaces, biophysical processes and their drivers (Fraser 2003; 15). The majority of 
research in Latin America on LUCC is focused on tropical forests, their deforestation and their importance to carbon and hydrological cycles, biodiversity, ecosystem services and regional climate change (Vadjunec, Schneider \& Turner 2003; 178).

Geographers are contributing towards understanding this global system of LUCC through studies on the causes of deforestation (Brothers 1997; Klepeis 2000; Klepeis and Turner 2001), biodiversity and land change (Snith et al 1996; Goulding et al. 1996), and land sustainability (Place 1993; Serrão et al. 1996; Southgate 1990; Matson et al. 1998). Studies conducted at local levels are placed into this global system of information to look at the sum of changes in LUCC on an international scale. Human-environment interactions at the local level play a significant role in understanding regional and global land transformations; creating a sum of local landuse practices and their resulting land-cover patterns create the global environment (Fraser 2003).

\section{Ecotourism}

Ecotourism is a rapidly growing industry that could address the conflict between conservation efforts and the needs of local populations. Ceballos-Lascurain (1993) defines ecotourism as:

"[T]raveling to relatively undisturbed or uncontaminated natural areas with the specific objective of studying, admiring, and enjoying the scenery and its wild plants and animals, as well as any existing cultural manifestations (both past and present) found in these areas, that have low negative impact on the environment. An important part of this process is to involve local communities in such a manner that they obtain social and economic benefits." 
For ecotourism to be successful within a protected area, it must focus on three concepts: it must be nature-based, educational, and economically and socially sustainable (Diamantis 1999; 93). Ecotourism differs from nature tourism, sustainable tourism, altemative tourism, adventure tourism and wildlife tourism because it is more than traveling to enjoy or appreciate nature; it includes minimizing environmental and cultural consequences, contributing to conservation and environmental education, and raising political awareness (Honey 1999; 6).

Suppoiters of ecotourism argue that local people can play a significant role in natural resource protection when they are given incentives to pursue ecotourism rather than resource extraction (West et al. 2003; 104). Under this argument, ecotourism encourages natural resource protection by providing economic opportunities to keep resources in place and not to over use or over extract resources, because that affects potential income from nonextractive activities (Honcy 1999). Supporters of ecotourism argue that if local residents of a protected area receive benefits through a bottom-up ecotonrism industry, they will have internalized the inportance of protecting natural resources. Onc example of this is in communities bordering Corcovado and Piedras Balances National Parks in Costa Rica. Stem et al. (2003) found that ecotourisin offers economic benefits and discourages the conversion of forests. They also found that direct incoune from ecotourism is having an impact on conservation practices. However, one concern that emerged from this study, is whether conservation strategies were practiced because they received direct economie 
benefits through ecotourism or if these perspectives were internalized and vould remain even if ecotourism were to collapse.

Additionally, supporters recognize that ecotourism can result in negative impacts on these protected areas, and on small rural communities, from inflation, increased migration into protected areas, economic dependency and instability, cultural deterioration, environmental contamination, overcrowding, or habitat disturbance and destruction (Nielson 1995; 13). An example of negative impacts is in the offshore coral reefs of the Maldives (Cater 1994). Destruction of the reefs stems from souvenir hunting, careless treatment from mishandling boats and scuba equipment, and direct trampling at low tides. Pollution has also resulted from ongoing site use, and petroleum and oil spillage from boats. In this case, destruction of the coral reefs resulted in the very resource that initially attracted tourists.

Many factors can influence the environmental impact of ecotourisn. Farrell and Marion (2001) conducted research on the ecotourism visitor impacts in eight protected areas in Costa Rica and Belize and found that unique unanagement conditions influence envirommental impacts. The staff and budget limitations of most management proved to be a barrier in minimizing visitor impacts, including educating and regulating visitors, and constructing and maintaining facilities. Another management issue is the competition for natural resources between local populations and protected area managers, and sharing natural resources between local and visiting populations. Other challenges in management issues that affect visitor impact are the 
lack of adequate infrastructure, tourist safety issues, poor distribution of tourist income between guides and protected area staff, and mismanagement of tourist fees.

At a small-scale, a community-based approach emphasizes local communities as partners in conservation and development. This builds on the ideology of Integrated Conservation and Development Programs (ICDP) which aim to increase economic opportunities for resource-dependent rural communities as a means of protecting nature without social problems caused by top-down, paternalistic approaches (Belsky 2003; 89). Communities must receive local economic benefits to compensate for the economic losses caused by the restrictions of a protected area that eliminate or reduce traditional resource use (Lindberg 1993). A community-based system of ecotourism is based on the idea that all members of the community will receive economic benefits and therefore actively participate in the conservation and protection of the natural environment that visitors are coming to experience. The link between ecotourism and economic benefits must be clear in order for ecotourism to act as an incentive towards conservation.

In addition to minimizing negative environmental impacts, it is important that ecotourism also minimize negative cultural impacts. The influence of outside cultures will of course, generate change, some will be positive and some will not. Some negative impacts that are of specific concern to the RPBR are the introduction of begging, nutritional degradation in the event that local people sacrifice (low) food supplies for visitors, increase in crime, adoption of outside cultural customs, change in diet due to presence of new food to meet visitor desires, and poor spending decisions 
on money earned through ecotourism (Anderson N.d.). Therefore, careful management and planning for the influx of ecotourists is essential,

The relatively recent development of ecotourism in protected areas presents questions and concerns about the results of using this industry as a catalyst for conserving and protecting natural resources. How can ecotourism be developed to ensure benefits for local people? Can negative impacts be avoided or minimalized? Is ecotourism a sustainable solution for natural resource management? Can rural populations accommodate an influx of visitors without exploiting natural resources? Is ecotourism a legitimate tool for preserving biological diversity and promoting sustainable development (Boo 1992)? The lack of long term evaluations of ecotourism in rural, indigenous communities located within the boundaries of a protected area, leaves many questions about the effectiveness of ecotourisin to meet the objectives established for the industry, unanswered. Documentation 1 offer in this thesis provides a base for future examination of the research area and allows researchers to answer some of the unanswered questions about using ecotourism as a tool for biodiversity conservation in protected areas. 


\section{CHAPTER THREE}

\section{LA MOSQUITIA AND THE RÍO PLÁTANO BIOSPHERE RESERVE}

The Mosquitia refers to an area on the Caribbean coast of Central America in the northeastem comers of Honduras and Nicaragua (Figure 3). It comprises a large part of the department Gracias a Dios in Honduras, and both the Northern and Southern Autonomous regions of Nicaragua. It is home to four indigenous groups, the Pech, Miskito, Tawahka, and Garifuna. The Río Plátano, Tavahka Asangni and Bosawas Biosphere Reserves protect a large portion of the Mosquitia (Figure 6). There is an attempt by Central American governments to create a corridor of protected areas between the Honduran and Nicaraguan Mosquitia to help ensure the preservation of its historical, cultural, and biodiversity (Herlihy 1999; 1997).

The Honduran Mosquitia is isolated from the remainder of the country, with limited access by road, boat, or plane. Initial surveys of the biodiversity and ecosystems of the Río Plátano watershed were conducted in a six-iveek period during 1977-78 by RENARE (Froehlich and Schwerin 1983; 6). The rugged terrain and lack of accessibility limited the number of personncl and amount of time available to conduct a developed survey. The isolation and ruggedness of the Mosquitia has also impeded settlement, but this is gradually changing as the development of a road from 


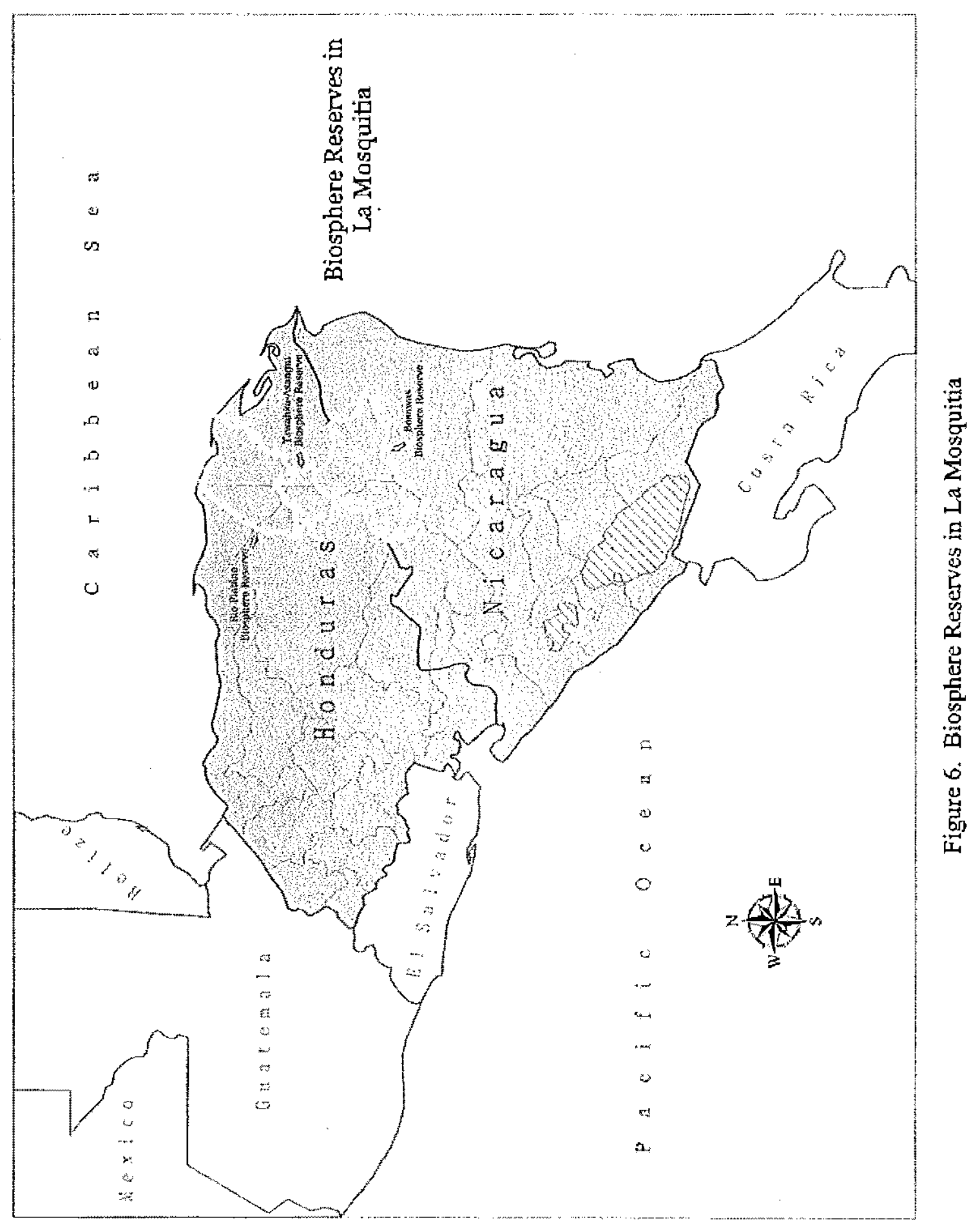


Olancho into the southwestern corner of the reserve progresses (Figure 5).

The Mosquitia coast has been defined by a series of economic cycles in which products, one at a time, were extensively exploited and exported from the area. Mary Helms (1971), who has documented cultural changes in a group of riverine Miskito in Honduras, noted exploitation cycles of various commodities including rubber, mahogany, gold and silver, bananas and pine. Bernard Nietschmann spent time with the coastal Miskito in Nicaragua and documented the sea turtle and lobster industry that has developed on the Caribbean coast since the 1970 s $(1973 ; 1997)$. The emerging economic cycle of ecotourism is similar to the past cycles in that it is still dependent on fluctuations of the disposable incomes and desircs of people outside of the reserve. Despite the outside economic cycles listed above, many residents of the Mosquitia are still dependent on subsistence farming, hunting, fishing, and traditional land uses.

\section{Río Plátano Biosphere Reserve}

\section{Creation of the Reserve}

The Río Plátano Biosphere Reserve (RPBR) (Figure 7) in Honduras was established in 1980 in accordance with UNESCO's Man and the Biosphere Program (MAB), and was expanded in 1997 to encompass 800,000 heetares. The Reserve is located between three departments -- Gracias a Dios, Colón, and Olancho - within the Mosquitia region of Honduras. Its borders are defined by the Río Sico/ Paulaya in the west, the Río Patuca in the east, the Río Wampu and Río Dapawas in the south and 


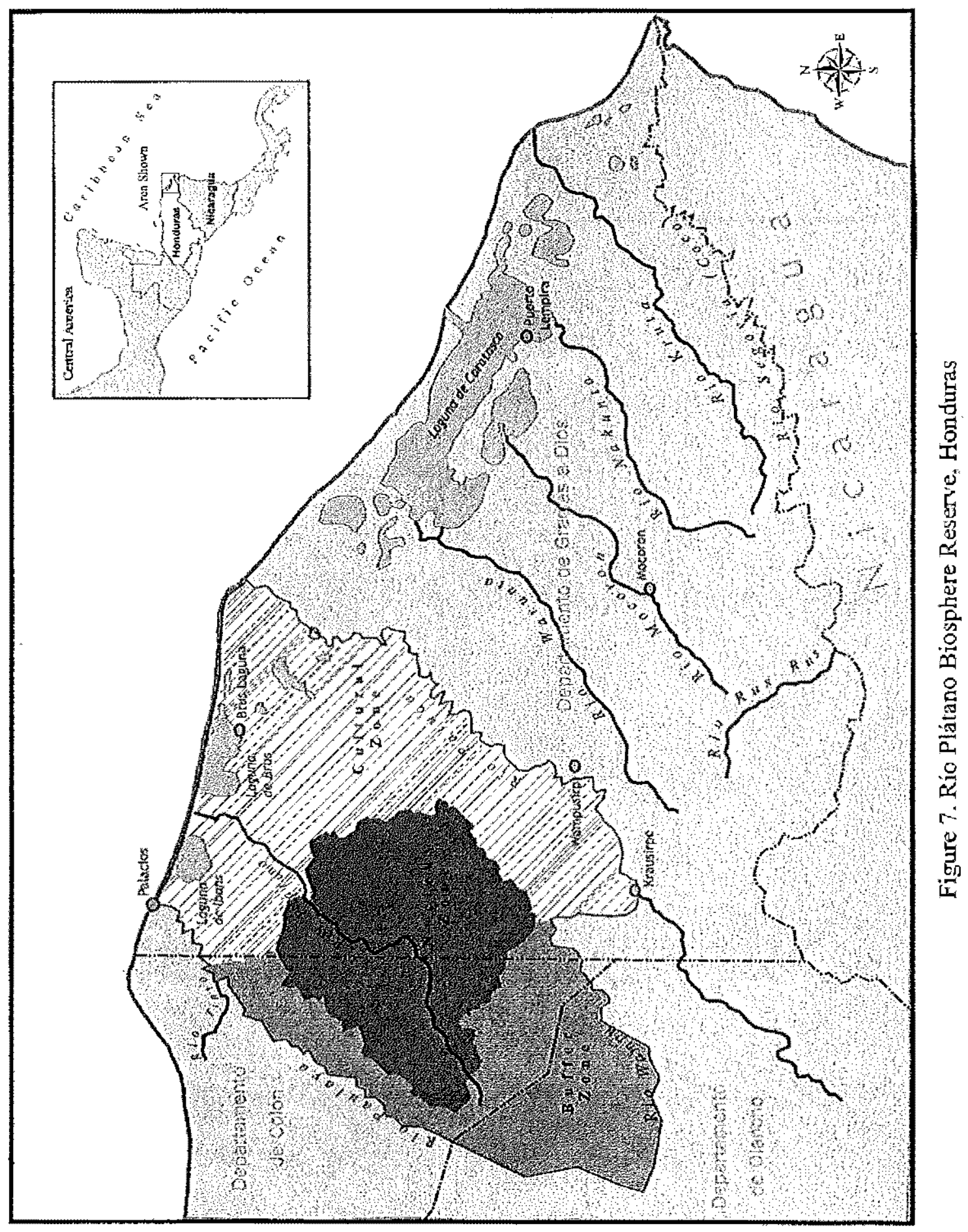


they extend five kilometers into the Atlantic Ocean to the north. It is the largest protected area in Honduras, and was the first designated biosphere reserve in Central America (AFE-COHDERFOR et a1. 2000; 1). The Honduran Mosquitia has received governmental attention since 1969 when an area (which the Río Plátano reserve currently encompasses) was set aside as the Parque Arqueologico National (National Archeological Park), a reserve in which all archaeological research and excavation would be legally controlled (Froehlich and Schwerin 1983; 5). The first biosphere reserve administration was in Kuri (located at the mouth of the Río Plátano) where a structure was built to serve as a guesthouse, administrative office and research center (Froehlich and Schwerin 1983; 6).

According to the biosphere model, the RPBR was divided into threc zones, a cultural, nucleus and buffer zone, corresponding with the definitions and establishments created by UNESCO (see Chapter Two). Additionally, a Participativa de Subzonificación (IPZ, Participatory Zonification Investigation) was conducted to further subdivide zones to reflect the self-defined land-uses of local populations (AFECOHDERFOR et al. 2000; 82). Participation in this investigation included indigenous and Ladino communities and was the fundamental basis in creating the management plan for the Río Plátano Biosphere Reserve.

\section{Flora and Fauna}

A 1983 prelininary inventory of flora and mammalian fauna in the Río Plátano Biosphere Reserve revealed a lack of information not only with rcspect to flora and 
fauna, but also in basic information about this region (Froelich and Schwerin 1983). The following eight areas needed more study: (1) the social and political organization of the region, (2) a complete biological or ecological inventory, (3) impact of local practices on the local or regional ecosystems, (4) inpact of the Moravian church on local practices and customs, (5) demographics, (6) general culture change, (7) a workable management plan and (8) more data concerning or implicating how natural resources are being used within the boundaries of the reserve. Since then, researchers have significantly contributed to the following topics: anthropology (Dodds 1987; 1994; 1998; Fraser 2003; Houseal et al. 1985), geography (Herlihy 1999; 1997; Herlihy and Leake 1997), biology (Glick and Betancourt 1983; AFE-COHDEFOR et al. 2002), economics (Sletto 1999), botany (House and Sanchez 1997; HerreraMacBryde 1994; Nelson-Sutherland 1986), ecotourism (Lagos and Guadado 1997; Anderson N.d.; Nielsen 1995; Nielsen and Munguia 1998; Nielsen et al. 2003; Macomber, Boxer-Macomber and Anderson N.d.;), and natural resource management (AFE-COHDEFOR et al. 2000; 2003).

According to incomplete survey data, the RPBR contains $10 \%$ of all plants, $27 \%$ of all amphibians, $36 \%$ of all reptiles, $57 \%$ of all birds, $68 \%$ of all manmals and $70 \%$ of all fresh water fish in Honduras (AFE-COHDERFOR et al. 2002; 109). If a complete flora and fauna inventory were conducted in the RPBR, those percentages would increase significantly, especially for flora and amphibians (AFE-COHDERFOR et al. 2002). In order to properly manage the reserve and its resources, it would be necessary to conduct an inventory of flora and fauna and assess the cultural 
utilizations of the area's forest resources. To date, there has been no comprehensive survey conducted in the nucleus zone of the reserve, nor has a research station been established or planned for the area.

The wildlife inventory of the reserve includes approximately one hundred and thirty mammals, thirty amphibians, seventy-five reptiles, thirty fresh and salt-water fauna, and four hundred and ten avian species (AFE-COHDERFOR et al. 2002). Many of these include species that can only be found within the limits of the reserve. There are also a number of endangered species, such as the Trichechus manatus (fresh water manatee), Panthera onca (jaguar), and Harpia harpyja (harpy eagle).

In 2002, an Environmental Diagnostic Report (Diagnostico Ambiental) was conducted for the RPBR, with contributions from various organizations and scientists throughout Honduras (AFE-COHDERFOR et al, 2002). In this report, 586 species of plants and 113 plant families were identified, which represents fever than $10 \%$ of the entire national flora. Of the 586 plant species, thirty have only been identified in the Mosquitia of Honduras and twenty-three of them were new for Honduras (AFECOHDERFOR et al. 2002). House and Sanchez (1997) estimate the total number of plant species in the reserve to exceed two thousand. The inaccessibility to the nucleus zone has created difficulties in conducting a thorough flora inventory. This is slowly changing as population pressures from the southwestern corner of the reserve have begun to encroach on the edge of the nucleus zone and permanent communities are being established despite park regulations. 
Physical Features

The majority of the reserve's population resides along the coastal spit, sandwiched between the Caribbean Sea and Brus and Ibans lagoons (Figure 7). On the other side of the lagoons are the two largest ecosystems found in the reserve, Humid Tropical Forest and Very Humid Subtropical Forest (Glick and Betancourt $1983 ; 170)$. The river system and lagoons lead to the Caribbean through five corridors: the Río Sico Paulaya, Río Plátano, Brus Lagoon, Río Patuca and Río Tinto. The Río Tinto corridor was established only four years ago when Tropical Storm Michelle hit and tore through the coastal spit (AFE-COHDERFOR et al. 2002; 32).

The two large lagoons, the Brus and Ibans, are situated on the northern (Figure 8) side of the reserve; the two lagoons and massive river systems in the reserve shapes transportation and access. The majority of supplies from outside the reserve (from other parts of Honduras, as well as other nations) enters on cargo ships with stops at towns located on the coastal spit between the lagoons and Caribbean Sea. From the coastal villages, goods are transported through the river systems to communities in the forested regions across the Ibans Lagoon and down the Río Plátano, Sico/Tinto, Patuca, among others.

The topography ranges from coastal plains and undulating lowlands to the high points of the Punta Piedra Mountains, creating a wide array of ecosystem types. The highest peaks in the reserve are the Punta Piedra at 1,326 meters, Mirador at 1,200 meters, Baltimore with 1,083 meters and Dama at 1,000 meters (AFE-COHDERFOR et al. 2002; 33). The topography differences create six ecological zones: Maritime, 


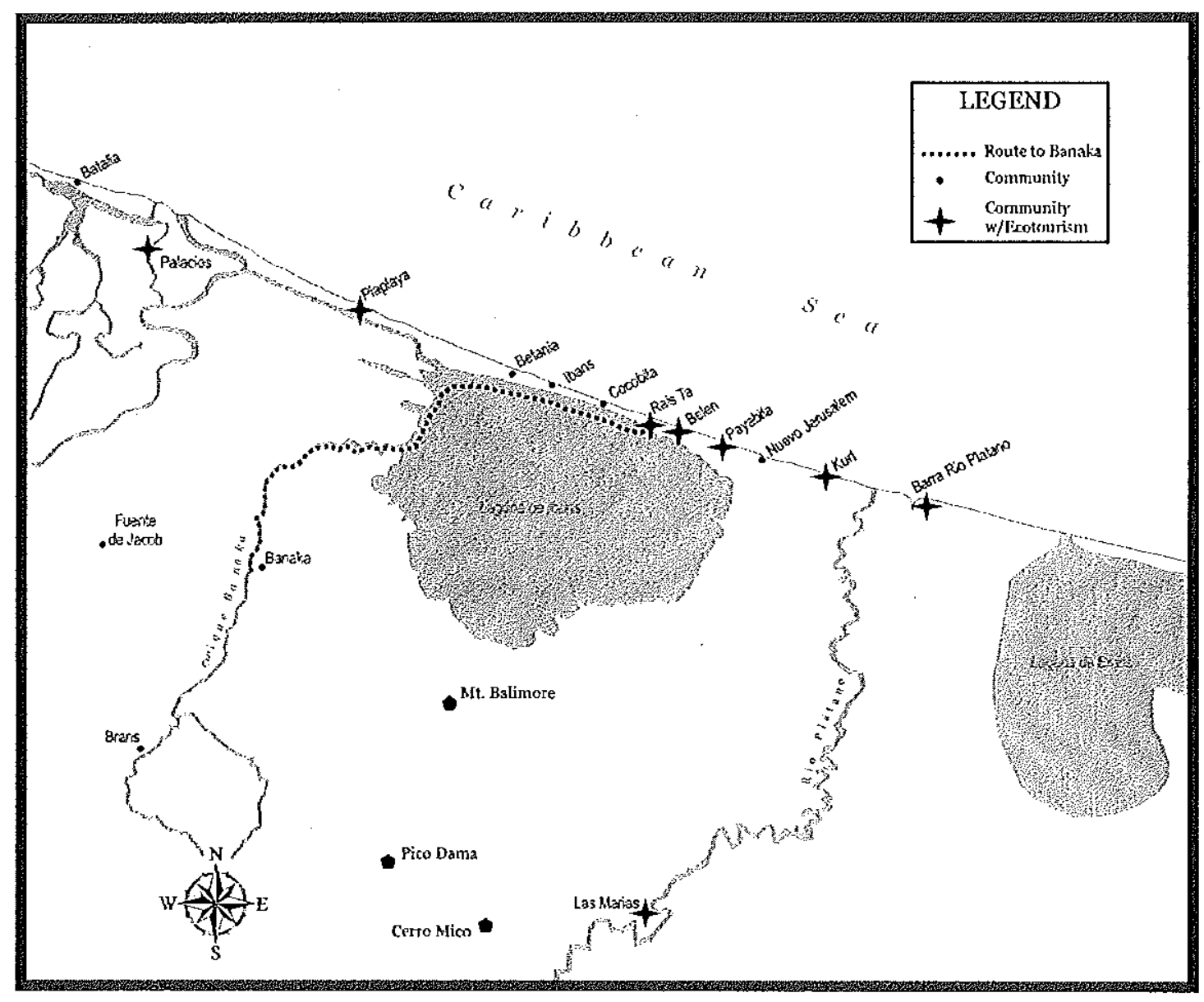

Figure 8. Caribbean Coast of the Río Plátano Biopshere Reserve, Honduras (not drawn to scale) 
Coastal, Rivers, Plains, Broadleaf Forests, and Humid Coastal, with a total of twentyfour ecosystems.

\section{Archeological Resources}

The RPBR is thought to be rich in archeological resources, but little research has been conducted to find and protect those resources. There are an estimated 200 archaeological sites including petroglyphs in Las Marias, Las Crucitas, Casa Piedra, along the Brans creek. It is believed that the legendary and undiscovered Cuidad Blanca (White City), a $16^{\text {th }}$ century Mayan site, is also located within the limits of the reserve.

\section{Ethnic Groups}

In 1980 the population of the reserve was approximately 500 and consisted primarily of indigenous groups (Glick and Betancourt; 1983; 171). In 1999 there were approximately 40,000 inhabitants in over 180 communities within the biosphere. Approximately $53 \%$ of the population are Ladino, $44 \%$ Miskito, 3\% Garifuna and 1\% Pech (Herlihy 1999; 107). The increase in population, specifically the Ladino population, is largely due to the migration of people from other parts of Honduras seeking land and the increase in the park boundary.

Currently Ladinos are the largest ethnic group in the reserve. The large Ladino population in the reserve stems from two waves of settlement, separated by almost a century. The first Ladino communities emerged during the early twentieth century with the establishment of banana plantations set up by the United Fruit Company. 
Ladinos initially traveled to the remote area of the present Río Plátano Biosphere Reserve to take jobs on plantations. After the fall of banana plantations, many of the Ladinos stayed. The original Ladino communities practice slash-and-burn agriculture, cash cropping of staple foods, hunting, fishing, and small-scale cattle-rearing, similar to the practices of the indigenous communities (Herlihy 1999; 105). The second wave of Ladino settlement started after the 1970s, mostly in the southwestern corner of the biosphere. These settlements emerged from people extracting mahogany and seeking land for agriculture and cattle raising. Today the Ladino communities participate in a cash-economy, with corn, beans, rice, and coffee cultivation for sale, as well as cattle and pigs for outside markets (Herliliy 1999; 105-6).

The majority indigenous population is Miskito, which comprises the two largest settlements of the reserve, Barra Patuca and Brus Laguna, along with several other Miskito towns. The Miskito economy includes marine and rain forest resources (hunting, fishing, and food gathering), and slash-and-burn cultivation (yucca, bananas, plantains, rice, beans, coln, sweet potatoes, and various fruits). Traditionally, seasons dictate Miskito settlement patterns: coastal settlements are occupied during the wet season (roughly June-July, and November-January) and populations move to riverine agricultural lands during the dry season (roughly February-May and August-October). A change in seasonal migration and settlement has occurred with the increase in alternatives to agriculture as the main source of sustenance. During the mid-1900s, the economy experienced significant change with the introduction of cash-earning activities from outside industries. The cash economy brought in store-bought foods 
and manufactured goods, which have now been integrated into typical Miskito life (Herlihy 1999; 103).

The Garifuna population is thought to have originated on the Caribbean island of Saint Vincent, sometime between the seventeenth and eighteenth century through a mixing of a Carib population, Afriean slaves, and French cleries and farmers. It is thought that they settled on the coast of Honduras sometime after Britain succeeded in taking over Saint Vincent in 1796 and forced the Garifuna to Central America. Today, the Garifuna population in the reserve resides on the coast, with Plaplaya being the one majority Garifuna community. They are considered fisherfolk, depending on the sea for a large portion of their livelihood, but they also rely on agriculture for subsistence (Macomber et al. N.d.; Herlihy 1999).

The Pech population is small and concentrated in and around the town of Las Marias along the Rio Plátano. There are very few people of pure Pech decent, as many have intermarried with Ladino and Miskito people. Both of these factors liave contributed to the loss of many Pech cultural traditions and language. Most Pech children speak Miskito or Spanish as their native language because of their sustained contact with the dominant Miskito and Ladino populations (Herlihy 1997; 104). The Pech in Las Marias are known for their stucessful ecotourism industry (see Chapter Seven), but still mostly depend on swidden agriculture, hunting and fishing for their livelihood (Macomber et al. N.d.). 
Reserve Management

Throughout the 1980 s the Río Plátano Biosphere Reserve was mainly a "paper park" with few park rangers, no management plan, and no support from local or state government. In the early 1990s the Honduran government sought financial support and consultation from the German government to assess and produce a management plan for the reserve. After almost a decade of negotiations, the Río Plátano Forestry Region Department (AFE/COHDEFOR) was established for conservation and enforcement within the reserve. After the 1997 approved expansion of the biosphere, a technical team consisting of geographer Peter Herlihy; the German agency Gesellschaft für Agrarprojekte (GFA), who performed the environmental assessment; the Río Plátano Biosphere Project (BRP); MOPAWI, an NGO working in the Mosquitia region; a university-trained Miskito leader; and several other local representatives worked to establish a community approved land-use zoning system. There were three specific objectives to the participatory zoning project; "(1) to incorporate reserve residents into research to increase their participation in the management and protection of the biosphere; $(2)$ to produce large-scale maps of community land-use in the reserve; and (3) to design a consensual zoning system that recognizes state-established regulations while respecting the existing land-use practices and proposals defined by the residents populations" (Herlihy 1999; 108). Workshops, surveys, data collection, analysis, and map production vere conducted over the next year to establish zone boundaries, management strategies, and land-use regulations. This zoning system was incorporated into the Plan de Manejo of the 
RPBR, finally established in the late 1990 s to reflect existing practices of the local communities as well as provide a regional consensus. In addition to the Plan de Manejo published in 2000, the Diagnostico Ambeintal was published in 2002, and the Normas para el Manejo y Proteccion de los Recursos Naturales y Culturales in the RPBR was distributed in 2003 (AFE-COHDEFOR et al.). These three documents, established by the combined efforts of the various groups working on the project, outline all management practices, resource extraction regulations and guidelines for the reserve.

There are constant threats to the conservation of the natural resources within the reserves' boundaries. With the inclusion of more land in 1997, along with a large number of rural settlers and refugees seeking land, the population of the reserve increased by $800 \%$ between 1980 and 1999 (Glick and Betancourt 1983; Herlihy 1999). Population increase is one of the largest conservation threats, creating a greater demand for agricultural land and hunting, and resulting in deforestation. HerreraMacBryde $(1994 ; 4)$ identifies the most serious threat as the cattle frontier moving from the southwest into the Wampú-Paulaya river area of primarily Ladino settlements. Illegal logging, mining, and road construction also threaten the conservation of lands within the reserve. Reserve management must continue to seek resident input and assess the changing human-environment interactions in order to effectively manage and conserve its natural and cultural resources. 
Land Rights

Land rights within the reserve are a pressing and sensitive issue. Legally, all of the land within the reserve belongs to the Honduran state. Traditionally, the indigenous populations have a system of community and personal land ownership and accumulation. Some Ladino populations have resided in the region for decades and have acquired land through historic claims. Additionally, current Ladino migrants are still settling within the limits of the reserve and acquiring land through purchasing or squatting. All of these factors create friction between the Honduran government, indigenous peoples and Ladino populations.

A series of state lavs have been established to clarify land ownership but many contradict one another and none specifically addresses an indigenous land rights policy. The Honduran Decree Law 170-97 guarantees that the inhabitants of the reserve can maintain their lifestyle, customs and traditions, and rights of land-use without limitations, but this does not guarantee title to the lands for communities. There is also confusion surrounding the administrative responsibilities for managing protected areas. The 1971 Forestry Law declares the Secretariat of Natural Resources responsible for park and reserve development. Two laws established in 1974 create agencies involved with protected areas, The Honduran Forest Development Corporation (COHDEFOR) and The Department of Renewable Natural Resources (RENARE). Later in 1991, the responsibilities of RENARE were transferred to the Protected Areas and Wildlife (DAPVS) section of COHDEFOR and they have assumed many of the responsibilities of management issues. The 1993 General Law 
of the Environment addresses the issues of protecting and conserving the environment and the importance of including local participation in the management of protected areas. To date, the indigenous peoples in Honduras do not have land titles and COHDEFOR regulates all management, monitoring, and resource extraction in the reserve.

In Miskito tradition "improved" land, either cultivated or fallowed, becomes the de facto property of the individual who clears it (Herlihy 1997; 113). Miskito leaders have been openly speaking with Honduran officials to gain land rights for almost thirty years. They formed the first indigenous federation, Unity of the Mosquitia (MASTA), which has been actively involved in gaining international support and developing a land legalization program with the assistance of Honduran NGO MOPAWI (Development of Mosquitia). MOPAWI has been working with the Miskito on issues such as legalization of lands, agriculture, small business development, women's development, bilingual education, vocational training, integrated management and ecotourism development since 1985 (Herlihy 1997; 109).

The struggle for inhabitants of the reserve to gain legal title to their land continues. The Honduran government has not historically recognized indigenous land titles. In July 2004, a revised draft of the Forestry Law was being developed and it was rumored that it would include the recognition of indigenous land rights and title to their land. It has not been approved and therefore legal status of indigenous land is still uncertain. 
Research Communities: Banaka, Brans, and Fuente de Jacob

The study area is located near the Caribbean coast, inland from the Ibans Lagoon along the Banaka Creek (Figure 8). In contrast to coastal communities located on the spit between the lagoon and Caribbean, the research area is considered to be located in the forested region of the reserve. Banaka has a town center and is the commercial, social and religious center for the surrounding communities of Brans and Fuente de Jacob. The communities in the study area vary in size, date of founding and ethnicity (Table 3).

TABLE 3

Community Profiles (Fieldwork 2004; Fraser 2003)

\begin{tabular}{|l|c|c|c|}
\hline & Banaka & Brans & Fuente de Jacob \\
\hline Date Founded & 1930 & 1997 & 1984 \\
\hline Dispersed/Centralized & centralized & dispersed & dispersed \\
\hline Majority Ethnicity & Miskito & Ladino & Ladino \\
\hline \# of households & 48 & 10 & 6 \\
\hline School & Yes & Yes & No \\
\hline School Founded & 1993 & 2001 & N/A \\
\hline \# of teachers & 2 & 1 & N/A \\
\hline Church & Yes & Yes & No \\
\hline \# of churches & 2 & 1 & N/A \\
\hline $1^{\text {st Church Founded }}$ & $\sim 1980$ & 2001 & N/A \\
\hline \# of Stores & 2 & 0 & 0 \\
\hline $1^{\text {st Store Founded }}$ & Unknown & N/A & N/A \\
\hline Medical Center & No & No & No \\
\hline Latrines & Yes & No & No \\
\hline Potable Water & No & No & No \\
\hline
\end{tabular}

The town of Banaka was officially established in 1930, but a more permanent population began to settle this area when the churches and schools were founded in the 1990s. It was and is still common for residents of the reserve to reside on the coast 
during the rainy seasons and work their agricultural fields in the forested regions during the dry seasons. Banaka started as an agricultural and hunting town and was established along the rich alluvial soils of the Banaka creek. Families would travel from coastal communities, approximately a four-hour canoe ride, for a few weeks of each planting/harvesting season and stay in temporary structures called champas (Figure 9).

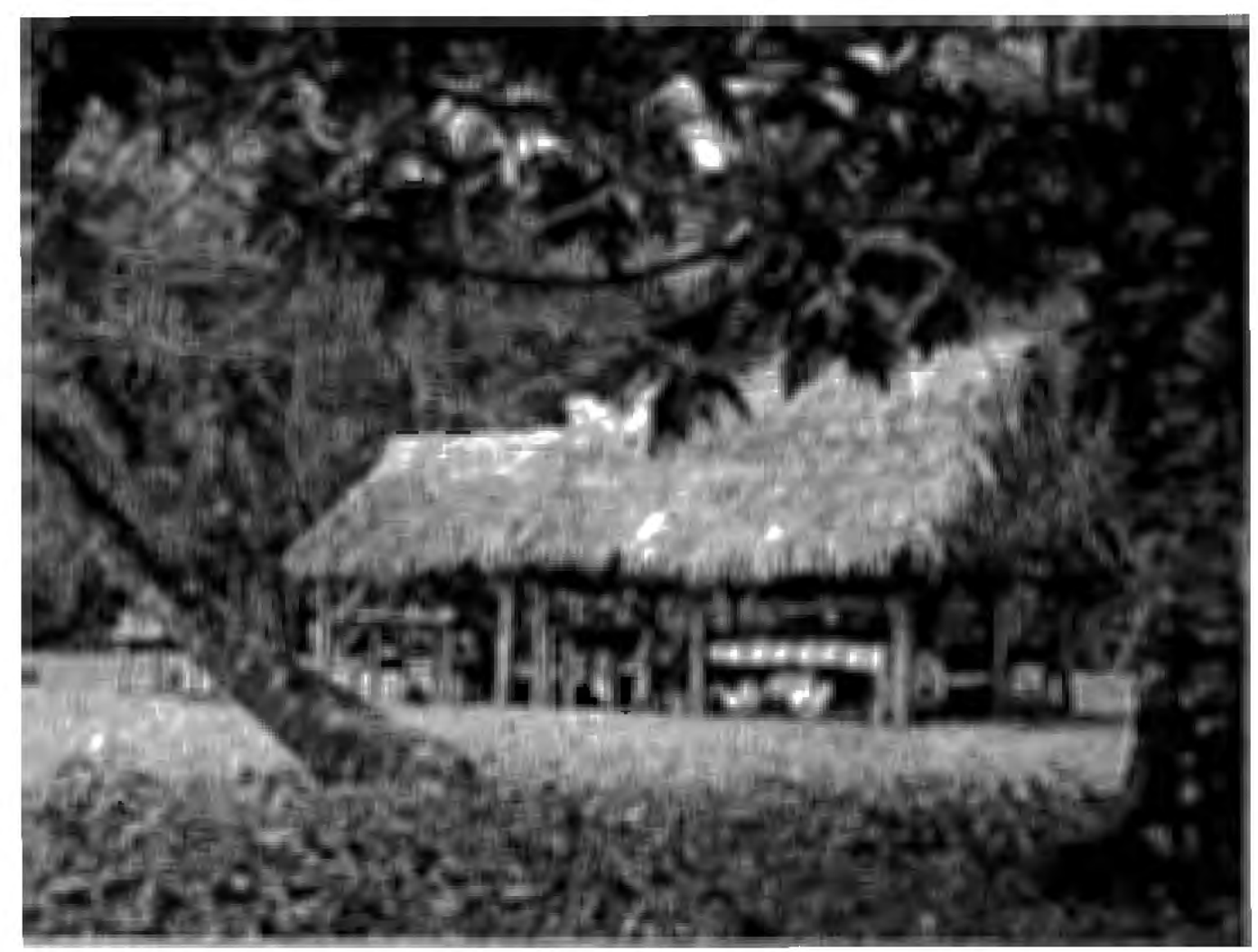

Figure 9. Traditional Miskito champa

Today most Banakan residents have clcared large plots of land along the creek to build their homes. Being near a water source is essential for access to drinking water, cooking, bathing, washing clothes, and transportation. Houses are most commonly built on stilts to avoid destruction in the case of flooding. Because of the 
necessity to build homes close to a water source, agricultural fields are not located along the riparian zones, which Froelich and Schwerin mention as being the most fertile because of periodic flooding $(1983 ; 26)$, they instead are located in the forests. Although still considered a forested region, the majority of the community land is pastureland, agricultural fields or guamiles (secondary growth forest on a fallowing field). In the smaller communities of Brans and Fuente de Jacob, there is no town center. Homes are dispersed and agricultural fields directly surround their homes (Figure 10).

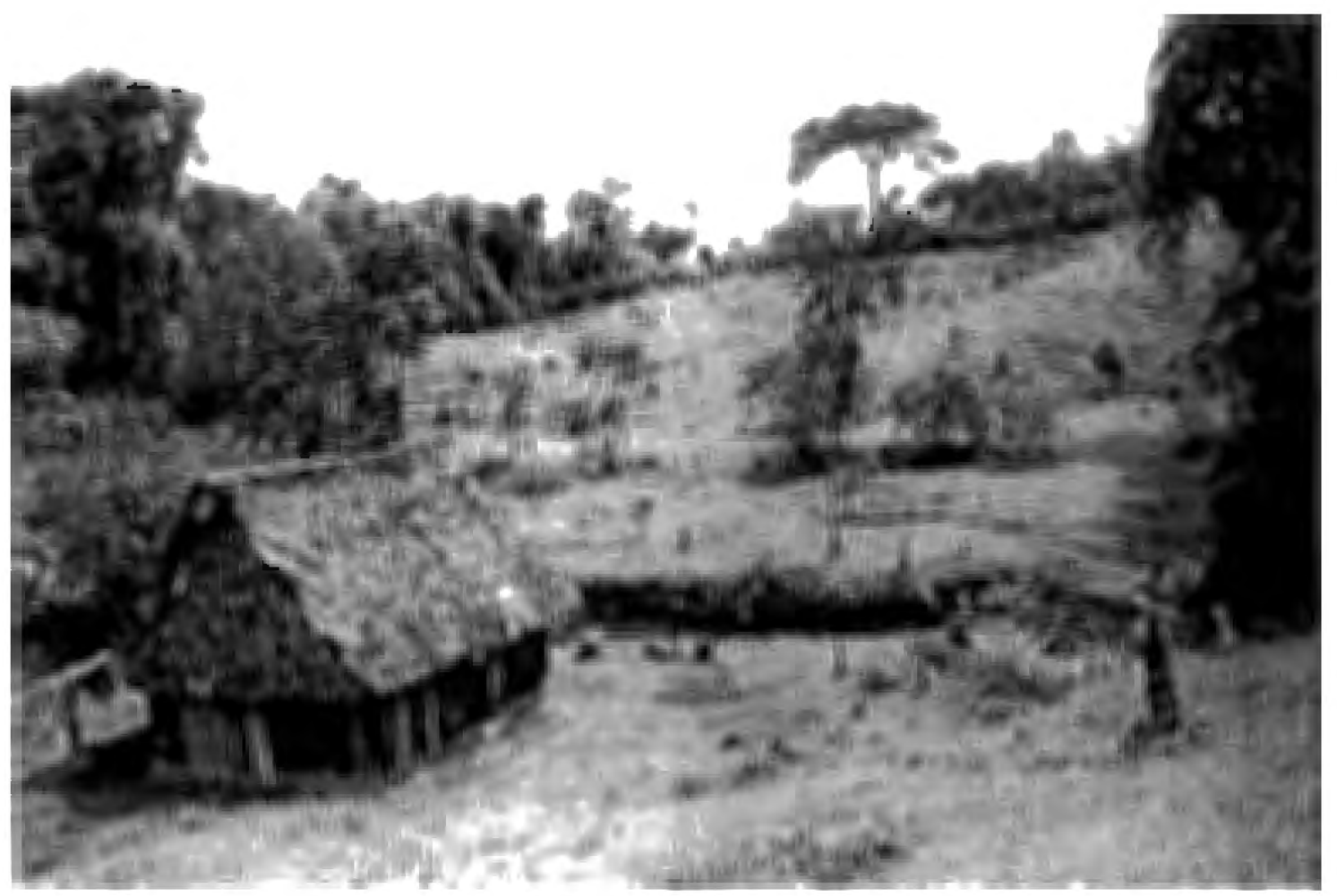

Figure 10. Typical Ladino household and fields The research comınunities have contrasting settlement patterns; Banaka and Fuente de Jacob were established slowly over time and continue to grow each year. Conversely, Brans was established in 1997 when a Miskito man divided his land into 
ten plots and sold it to ten different families (Fieldwork 2004). This happened despite the fact that land within the reserve is officially owned by the state of Honduras and indigenous people have no legal right to land or selling it. This deal initially created many tensions between residents of Banaka and new inhabitants of Brans. Most differences have been worked through, but people in Banaka still attribute unsustainable natural resource practices and environmental degradation of the area to the residents of Brans.

Banaka Creek is the main transportation channel for Banaka and part of Brans. Damming portions of the creek was necessary in order to maintain sufficient streamflow year round (Fieldwork 2004). Trees along the riparian zone of the creek are easiest to transport, therefore they are first to be cut down. This leads to erosion and sediment accumulation in the creek, creating a greater need to manipulate streamflow. The continued degradation of riparian areas accompanied by population increases, continues to affect the transportation channel. During the dry seasons it is difficult to navigate canoes along the creek, when some reaches are only a few inches deep. This makes it especially challenging for large canoes to travel the creek, which in turn limits the amount of supplies that are brought in and out of the region. Since many people in the area have a house on the coast, the creek is essential for transporting goods to the coast for consumption during the rainy seasons or to sell. This transportation route is also necessary to keep goods stocked in Banaka stores. It supplies goods to the residents of Banaka, Brans, Fuente de Jacob and other nearby towns. The stores are typically stocked with sugar, rice, flour, cigarettes, 
lollipops, soap, spaghetti, coffee, vegetable shortening, salt, matches, baking powder, chicken bouillon, juice mix (Tang), and cookies. The Banaka stores offer fewer goods than those on the coast. Frequently purchased items such as vegetable shortening, sugar, coffee, rice, and flour are not available at times. Residents wait anywhere from one to seven days for the stores to restock. In addition to seasonal weather patterns, severe unexpected weather can also affect the ability to travel to the coastal communities to restock provisions.

The Río Plátano Biosphere Reserve has remained protected and preserved because of its geographic remoteness, isolation and inaccessibility. This has been changing in recent years due to advances in transportation to the region, especially with the development of a road from Olancho and population increases from migration and lack of birth control with local populations. The same processes are evident in the Banaka region. As population increases and more land is cleared for agricultural production, the protected character of the reserve will be diminished. 


\section{CHAPTER FOUR}

\section{METHODOLOGY}

The primary objective of this research is to identify forest resource use and land use in the agricultural towns of Banaka, Brans, and Fuente de Jacob, which will provide base information prior to the introduction of ecotourism into the area. Banaka was chosen for several reasons; (1) it is depcndent on subsistence agriculture, (2) it is located in the forested region of the reserve, (3) it has been the location of agricultural plots for a minimum of four generations, (4) permanent settlement in the area has increased over the last ten or so years, (5) it is in the initial stages of establishing an ecotourisin industry, (6) pristine rainforests still exist in isolated areas, (7) new agricultural settlement is still occuring, (8) many coastal reserve residents come to this area to collect forest resources, and (9) it represents common issues in natutal resource management.

The fieldwork for this thesis was conducted over thirteen weeks from late April to late July of 2004. During this time I collected data through formal and informal interviews, collecting and identificating plants, participant observations, archival research, collecting Global Positioning System data points, and documentating community events and resource extraction. Of the three months spent 
in Honduras, eight weeks were spent in Banaka from May to early July. Because of Banaka's centrality to other smaller surrounding villages, I was able to meet and talk with people from the towns of Brans, Fuente de Jacob, Camaronil, Sassinting, and Ibilal. The short dry season was ending and the short rainy season was beginning during my time in Banaka. The months of March and April were unseasonably wet, causing trouble in burning and preparing fields for their agriculture. All fields that I visited still had significant debris after burning and all residents were concerned about the implications of the weather on this years' crops (Figure 11).

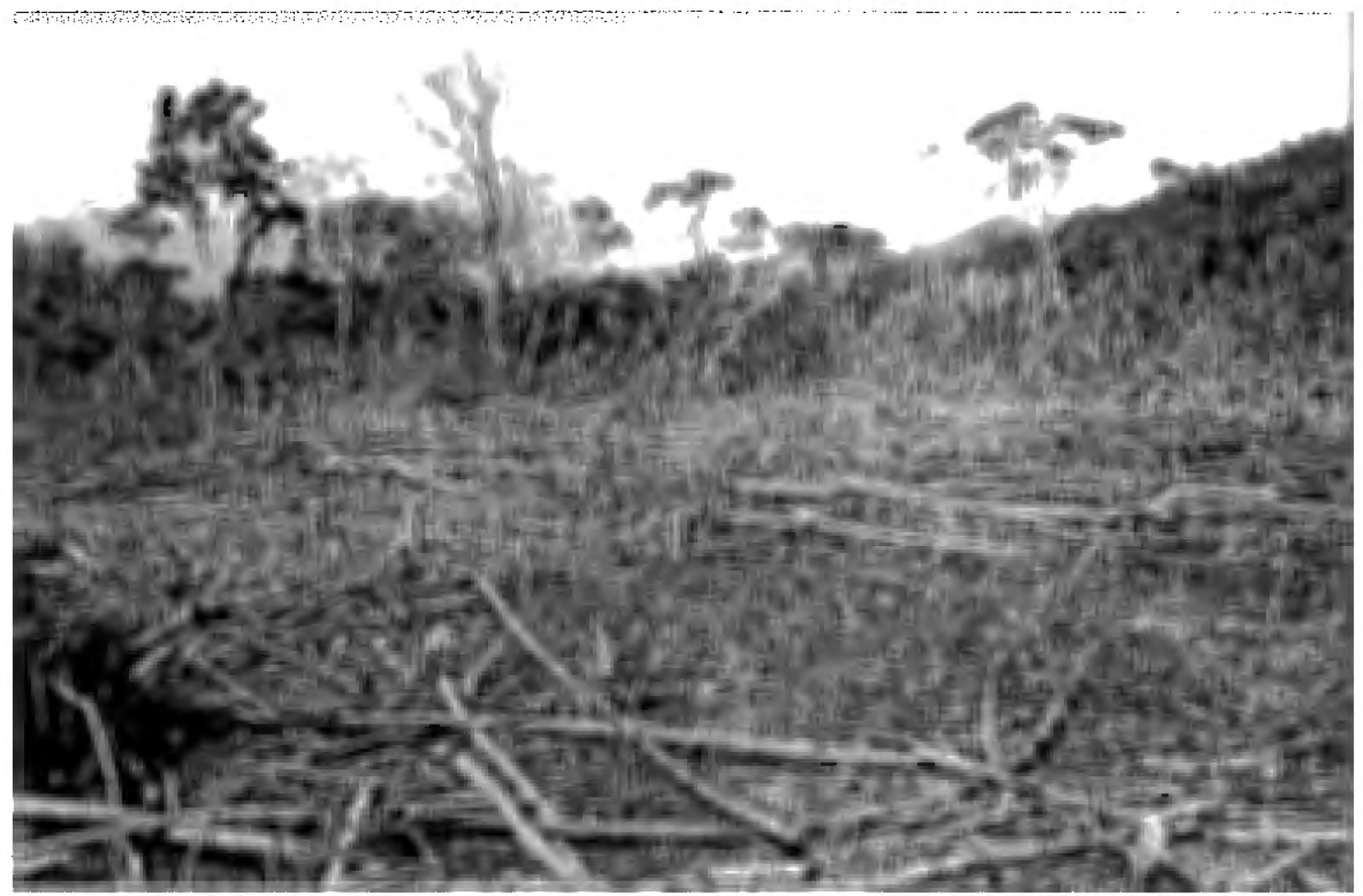

Figure 11. Agricultural field, May 2004 


\section{Household Surveys/Formal Interviews}

The household survey and formal interview questionnaire (Appendix A) were combined to include questions about the uses and collection of plants and trees, household demographic information, livestock, ecotourism, park regulations, agricultural plots and crops, distance to agricultural fields, and the sale and trade of agricultural and forest resources. The initial questionnaire was designed prior to arriving in Banaka, but was slightly altered after I was in Banaka for a short period of time. Two sections (plant-use and agricultural fruit trees) of the formal interview were altered after the first sixteen interviews. I changed this format because it became apparent that participants had difficulty recalling information on the spot. For the first sixteen interviews, the interviewees responded to questions number six (What do you plant? What type of crops and fruit trees?) and nine (Do you use plants from the forest to prepare food or for medicinal purposes? What do you use and what is it for? Do you collect it from the forest or obtain it from another source? It is abundant?) with little prompting (Appendix A). After the initial sixteen interviews, a list of fruit trees and plants was compiled and used for the remaining seventeen interviews. The list was read off during the interview to get a response and participants were asked at the end of the question if they could add any more information.

The surveys took anywhere between thirty minutes to two hours and on average lasted about 45 minutes. These surveys were conducted in Banaka, Brans, and Fuente de Jacob. One interview was conducted in Brans with a family from Ibilal, about a three-hour walk from Banaka. Of the three main towns in which surveys were 
conducted, approximately $61 \%$ of households were surveyed (Table 4 ). It was not possible to interview all the households for various reasons: (1) the short duration of fieldwork, (2) difficult conditions in traveling and accessing remote households, (3) seasonal residency of some families did not include the time of fieldwork, and (4) seasonal residents were occupied with agricultural work during their stay. In Banaka, there were at least five households that were not present at all during the span of fieldwork. Other households were only present for a short period.

\section{TABLE 4}

Number of Interviews by Community

\begin{tabular}{|l|c|c|}
\hline \multirow{2}{*}{ Community } & \multicolumn{2}{|c|}{ Households } \\
\cline { 2 - 3 } & $\begin{array}{c}\text { Total } \\
\text { Number }\end{array}$ & $\begin{array}{c}\text { Number } \\
\text { Interviewed }\end{array}$ \\
\hline Banaka & 48 & 22 \\
\hline Brans & 10 & 5 \\
\hline Fuente de Jacob & 6 & 5 \\
\hline Ibilal & Est. 20 & 1 \\
\hline
\end{tabular}

\section{Informal Interviews}

Informal interviews were conducted in numerous ways. In some cases after a formal interview I would continue to talk with the interviewee about a specific topic that they were interested in or knowledgeable about. Other times informal conversations would occur during travel, while watching a town soccer game, or visiting. Informal interview topics include the lobster industry and diving, life histories of town elders, environmental and cultural history, local or regional projects, education system and schooling, involvement of COHDEFOR and MOPAW1 in the 
reserve, social relationships, land-rights, religion, ecotourism funding and roles, and town politics. Informal interviews also included discussions with individuals outside the research area, including employees from COHDEFOR, MOPAWI (both in Tegucigalpa and the RPBR), Tear Fund, the Anthropology and History Institute, as well as residents of the reserve in Belen, Rais Ta, and Palacios.

Informal interviews provided a casual atmosphere to discuss issues related to my research and allowed participants to feel more comfortable. Because these interviews were usually conducted while other activities were occurring, in the evening or on Sundays, it offered the participants a chance to discuss a wide variety of topics not confined by the structured questions in the formal interview.

\section{Plant Collection}

Based on information from the formal interviews I developed a list of plants used for culinary and medicinal purposes. Other medicinal plant surveys have been conducted in the Mosquitia, the most comprehensive one being done by Paul House and Inalesio Sanchez (1997). I used their plant index for identification purposes, along with plants listed in the Reserva del Hombre y la Biosfera del Rio Plátano: Diagnostics Ambiental (AFE-COHDEFOR et al. 2002) and the Mamual Popular de Plantas Medicinales Communes de la Costa Atlantica de Honduras put together by the TRAMIL Program (Lagos and Guadado 2001). I collected plants not found in any manuals. During the collection process, four local residents with detailed knowledge of local flora assisted in field identification of plant samples. 
After plant samples were collected and pressed, Dr. Cyril Hardy NelsonSutherland, a botanist and professor at the Universidad Nacional Autónoma de Honduras in Tegucigalpa assisted with final identification (Nelson 1986).

\section{Participant Observation}

During my stay in Banaka, I was able to participate in daily activities which provide a deeper understanding of practices and people of the region. These activities included attending town meetings, witnessing a land conflict discussion, gathering crops, caring for livestock, maintaining house gardens, washing laundry at the creek, preparing meals, clearing land at prospective ecotourism sites, and being present during COHDEFOR related activities for granting resource extraction permission.

Each activity provided insight into relationships and interactions between people of Banaka and surrounding towns. Of the three town meetings that I attended, two concerned the comite vigilante, a committee established to monitor natural resource extraction in the forests surrounding Banaka, Brans, Fuente de Jacob, and other nearby small communities. The first meeting established processes for policing resource extraction and defined the roles for future committee members. The second followed up with committee nominations and voting. An ecotourism meeting was also held to discuss possibilities for the town (Appendix B). 


\section{Archival Work}

During the three months of fieldwork, I spent two weeks at the beginning and end of my stay in Tegucigalpa and La Ceiba conducting library research. The information gathered in Honduras was critical to my research and provided documents that could not have been gathered otherwise. These documents included reports written by MOPAWI about the reserve, copies of the RPBR management plan, an environmental diagnostic report and norms for natural resource and land-use published by AFE-COHDEFOR, and other documents, books and reports with limited publication in Honduras. The offices of MOPAWI, COHDEFOR, Universidad Nacional Autónoma de Honduras, Instituto Geográfico Nacional, Guymuras (a bookstore containing many Honduran publications), and the Instituto de Antropología y Historia, provided materials and photocopied documents.

\section{Description of Research Participants}

In Banaka $46 \%$ of households participated in interviews; in Brans, $50 \%$; in Fuente de Jacob, 83\%; and in Ibilal, 5\% (Table 5). Because only one household in Ibilal was surveyed it is not appropriate to generalize to the whole community based on limited information. For that reason, the interview from the Ibilal household was only included when conducting analysis based on ethnicity. 
TABLE 5

Participant Demographics

\begin{tabular}{|c|c|c|c|c|c|c|c|c|}
\hline Community & $\begin{array}{c}\text { \# of } \\
\text { Households } \\
\text { Interviewed }\end{array}$ & $\begin{array}{c}\text { \# with } \\
\text { Head of } \\
\text { House- } \\
\text { hold }\end{array}$ & Sex & & $\begin{array}{c}\text { Marriage } \\
\text { Status }\end{array}$ & & Ethnicity & \\
\hline Banaka & 22 & 14 & Male & 13 & Married & 18 & Miskito & 17 \\
\hline Brans & 5 & 4 & Female & 9 & Single & 4 & Ladino & 5 \\
\hline $\begin{array}{c}\text { Fuente de } \\
\text { Jacob }\end{array}$ & 5 & 3 & 4 & Married & 4 & Miskito & 0 \\
\hline Ibilal & 1 & 1 & Female & 1 & Single & 1 & Ladino & 5 \\
\hline
\end{tabular}

Since the majority of interviews were conducted in Banaka, the majority of interviewees were Miskito. The other ethnic group was Ladino, which is the name for Inainland Hondurans who have identified themselves as ethnic Honduran for generations and can be a mix of multiple ethnicities, including part Miskito (Table 6).

TABLE 6

Ethnic Diversity of Research

Participants

\begin{tabular}{|c|c|c|}
\hline Ethnicity & Ladino & Miskito \\
\hline $\begin{array}{c}\text { Number of } \\
\text { Participants }\end{array}$ & 16 & 17 \\
\hline $\begin{array}{c}\text { Average } \\
\text { Household Size }\end{array}$ & 5.6 & 4.9 \\
\hline
\end{tabular}

The average household size reflects a particular moment in time. Coinposition of households in all three towns varies; it is common for family members to move 
around often, visiting to help out with agriculture, newborns, or elderly parents. In Banaka people often have second homes located on the coast and the number of family members in Banaka at any one time varies depending on season.

It is more common for Miskito families to have a second home (Table 7). Second homes are common among Miskito since permanent residence in agricultural towns, such as Banaka, is a more recent tradition of coastal culture. Most Miskito still have homes in their birth town or near other family members. Ladino residents, on the other hand, have typically moved to the reserve in search of land, left their previous homes behind, and reside permanently in the research area.

\section{TABLE 7}

Number of Households That Occupy a Second Residence

\begin{tabular}{|c|c|c|c|c|c|c|}
\hline & \multicolumn{2}{|c|}{ Total Households } & \multicolumn{2}{c|}{ Miskito } & \multicolumn{2}{c|}{ Ladino } \\
\hline \multirow{2}{*}{ 2nd Houses } & Yes & 16 & 12 & $71 \%$ & 4 & $25 \%$ \\
\cline { 2 - 7 } & No & 17 & 5 & $29 \%$ & 12 & $75 \%$ \\
\hline
\end{tabular}

Settlement patterns in these communities are a function of official founding periods. In Brans, a Ladino community, land was divided and sold in 1997 all at one time thus there is little variation in settlement. Land ownership and rights are a complex issue in the reserve as was discussed in Chapter Three. In contrast, residents of Banaka have permanently resided in town for up to 47 years and have been farming the area even longer. Some residents of Fuente de Jacob, a Ladino settlement, have lived in the area up to twenty-two years, two years before the community was officially founded. Fuente is a well-established Ladino community and residents who settled before 1996 are officially regarded as permanent residents of the reserve. 
The pool of participants interviewed for this thesis are representative of this region of the reserve because participants include a range of ethnic groups and are from towns with various settlement patterns, and lengths of residency. Therefore, observations of forest resource and land-use patterns represent a range of socialenvironmental interactions in the Río Plátano Biosphere Reserve. 


\section{CHAPTER FIVE FOREST RESOURCES}

Natural resources within the forested region of the Río Plátano Biosphere Reserve provide many basic commodities for local inhabitants. The isolation of this area and the difficulty of procuring goods from outside sources, require that most subsistence goods be obtained from their surroundings. Proximity and abundance of resources shapes how residents of this area use the forests. Use has changed over time, because of population growth and boom and bust industry cycles of mahogany logging, banana cultivation, rubber tapping and fishing (Helms 1971; Nietschmann 1973; Dodds 1998). For example, mahogany is now scarce and at the same time is highly desired by residents throughout the reserve for canoe and house construction. The lack of mahogany has encouraged residents of the research area to begin planting mahogany trees. As the uses and demands for forest resources evolve, so do cultivation and extraction practices.

Strategies for gathering forest products vary according to location and forest type. The most commonly used plants are typically found growing openly in the cleared pastures or in guamiles (second growth forests on fallowing lands). Robert Voeks found that medicinal foraging habitats of rural tropical groups are typically 
humanized landscapes, such as trails, swiddens, kitchen gardens and recent fallow fields $(2004 ; 869)$. Voeks summarized research conducted world-wide on plant use in rural tropical communities: the open pastures of Banaka found in the town center, as well as the clearings surrounding houses outside the town center, are typical of the humanized landscapes Voeks studied, and are primary gathering areas for medicinal plants. Guamiles, found at the edge of Banaka's town center and throughout forests that surround towns in the research area, are agricultural fields currently in fallow or disturbed areas along paths that navigate through forests. Residents use plants found in guamiles and open pastures because they are abundant, near at hand, easy to harvest and are frequently rich in bioactive compounds (Voeks 2004; 878). The participant research population rarely collected plants found only in primary forests, situated in the distant hills. Accessibility influences which items are gathered and from where, as the gatherer must haul bulky or heavy items. Horses and canoes can be used, but many people do not own horses and canoes are only useful when a waterway is nearby. Although it is common to collect a plant for medicinal or provisional purposes while traveling through primary forests, people do not make specific trips to primary forests to gather plants. It is also common for people in the research area to collect medicinal plants only when modern medicines are not available or affordable.

\section{Gathered Plant-Use}

Plants gathered in the research area are used for both culinary and medicinal purposes (Table 8). Culinary and medicinal plants are gathered from forests and are 
also cultivated in solares and agricultural plots. This section will focus only on plants collected in forests and guamiles. Cultivated plants are discussed in Chapter Six.

\section{TABLE 8}

Uses of Commonly Gathered Plants ${ }^{1}$

\begin{tabular}{|c|c|c|c|}
\hline \multicolumn{2}{|c|}{ GATHERED PLANTS } & \multirow[t]{2}{*}{ Culinary ${ }^{2}$} & \multirow{2}{*}{$\frac{\text { Medicinal }^{2}}{6 \%}$} \\
\hline Milkweed & Asclepias curassavica & & \\
\hline Calaica & Momordica charamia & & 55 \\
\hline Mahogany & Swietenia macrophylla & & 21 \\
\hline Cedro Macho & Carapa guianensis & & 33 \\
\hline Chichimora & Fenillea cordifolia & & 55 \\
\hline Corozo & Elaeis spp. & $18 \%$ & \\
\hline Cucumeca & Dioscorea spiculiflora & & 18 \\
\hline Dormirlona & Mimosa pudica & & 6 \\
\hline Monkey's Ladder & Banhinia gutanesis & & 39 \\
\hline Flor de Muerto & Tagetes erecta & & 48 \\
\hline Frijolillo & Sema occidentalis & & 45 \\
\hline Ginger & Zingiber Officinale & & 39 \\
\hline Guaco & Aristolochia grandiflora & & 36 \\
\hline Kerosen & Tetragastris panamensis & & 12 \\
\hline Madriado & Elinicidia sepinm & & 42 \\
\hline Malva & Sinta acuta & & 30 \\
\hline Chamonile & Matricaria commantiana & & 48 \\
\hline Matuerza & Hyptis verficillata & & 33 \\
\hline Nance & Byrsomima crassifolia & 39 & 36 \\
\hline Pakeya & Chanaedorea neurochlamys & 30 & \\
\hline Palmiche & Elaeis oleifera & 27 & \\
\hline Palo de Sangre & Virola koschyi & & 27 \\
\hline Puta Sico & Spermacoce ocymifolia & & 6 \\
\hline Santa Maria & Piper auritum & & 33 \\
\hline Tres Punta & Neurdaena lobata & & 48 \\
\hline Cat's Claw & Solamim sp. & & 36 \\
\hline Lemon grass & Cymbopogon citratus & & 48 \\
\hline Zapaton & Pachira aquatica & & 45 \\
\hline
\end{tabular}


If current forest resource practices remain eonsistent and population growth continues, plant collection will also increase. Currently the guidelines outlined in the Normas para el Manejo y Proteccion de los Recursos Natural y Culturdes (AFECOHDEFOR et al. 2003) handbook restrict (1) cutting the entire plant (unless unavoidable or necessary); (2) destroying medicinal, omamental or fruit trees/plants; (3) cutting trees for the sole purpose of harvesting its fruits or medicinal parts; (4) extracting for commercial purposes; (5) collecting for people outside of the reserve; or (6) using areas that are designated by communities as special use areas. These restrictions support plant management, but other factors affected by population growth, such as increased agriculture and clearing of land for houses, also influence the habitats in which these plants grow. The handbook also outlines permitted plant gathering activities. It encourages the establishment of specialized zones designated for protecting medicinal and culinary plants in various aged forests, as well as cultivating medicinal and culinary plants. The management and protection of habitats and species will be more effective with information about the collection and cultivation of forest plants available about all regions of the reserve.

Access to altematives to forests products is affecting the frcquency of collection. Medicinal plants are quickly being replaced with pharmaceuticals in the research communities. Not only are they being replaced with pharmaceuticals, but the knowledge associated with those plants is being lost. Most people in the research area could list what plants are used for medicinal purposes but could provide only minimal information about how they were used. Younger men and women could easily recall 
which specific plants are used medicinally, but infrequently use them. The two participants most knowledgeable about medicinal plants were older gentlemen - a sixty-four year old Ladino and a fifty-year-old Miskito. Both lived in the Banaka region for many years: twenty-four and twenty-one years respectively, They were able to talk in detail about a large variety of plants, many of which were found in primary forests as opposed to guamiles or pastures. They also know which parts of the plant to use, for what reason, and where the plant could be found (one gentlemen was a guide during the collection process for plant identification). It seems that with an increase in population, income or ecotourism, the use of gathered plants for medicinal purposes will be replaced by purchased pharmaceuticals.

\section{Tree-Use for House Construction}

In the research area, trees are used for food and medicinal purposes, construction of homes and canoes, and firewood. This sectiou focuses only on treeuse for house construction. $^{3}$

All participants identified more than one tree used in the construction of their home. Different types of trees were used for rafters, posts, boards, and roofing. Overall, participants identified thirty-four types of trees for use in the construction of their homes; only seventeen were used in two or more homes (Table 9). All trees identified

\footnotetext{
${ }^{3}$ Firewood is used to heat the stove/oven in each household. Data was not collected on the amount or type of trees that were used for firewood because residents only use down trees cut for other reasons. For example, people collect medium sized logs for firewood from slashed and burned fields. Residents also use downed wood found in nearby guamiles. Data was not formally collected on trees used for making canoes. In informal interviews and conversations I discovered that many common trees used in house construction were also used for canoes. These trees, such as Mahogany, Laurel, Santa Maria, and San Juan, are all hardwood, large and durable trees desired to build any long-lasting structure.
} 
for house construction can be found in the forests around Banaka, Brans, and Fuente de Jacob; it was not necessary for any household to purchase wood for their homes. Trees used for house construction are found in forests that are known to be community land or on land that is considered their own based on traditional rights. The majority of households perform all tasks involved in preparing trees for house construction. In cases where there are no adult males in the household, a family will pay a friend or community member to harvest and prepare the wood and construct the house.

TABLE 9

Trees Commonly Used for House Construction ${ }^{4}$

\begin{tabular}{|l|l|c|c|}
\hline \multicolumn{2}{|c|}{ Species of Tree } & $\begin{array}{c}\text { Households } \\
\text { use }(\$)\end{array}$ & $\begin{array}{c}\text { Households } \\
\text { use }(\%)\end{array}$ \\
\hline Laurel & Cordia alliodora & 23 & 69.7 \\
\hline Santa Maria & Calophyllum brasiliense & 20 & 60.6 \\
\hline Suita & Calptrogyne sarapiquensis & 19 & 57.6 \\
\hline Mahogany & Swietenin macrophylla & 14 & 42.4 \\
\hline Areno & Andira inermis & 11 & 33.3 \\
\hline Manga Larga & Xylopia sp. & 11 & 33.3 \\
\hline San Juan & Tabebuia rosea & 7 & 21.2 \\
\hline Carbon & Piptadenia sp. & 6 & 18.2 \\
\hline Cedro Macho & Carapa guianensis & 6 & 18.2 \\
\hline Paleta & Dialium guianense & 5 & 15.2 \\
\hline Bamboo & Guadua sp. & 5 & 15.2 \\
\hline Cedro & Tapirira sp. & 4 & 12.1 \\
\hline Corozo & Elaeis spp. & 3 & 9.1 \\
\hline Yagua & Roystonea dinlapiana & 3 & 9.1 \\
\hline Cedro Real & Cedrela fissilis & 2 & 6.1 \\
\hline Nigritu & Bursera simaruba & 2 & 6.1 \\
\hline
\end{tabular}

${ }^{4}$ For a complete list of trees used for house construction in the research area see Appendix B. This list includes Spanish, English and Latin names, 
House styles can vary according to distance from water source and household income. Many houses are built on stilts when the potential for flooding is evident (Figure 12). Income can affect the style of house; if boards are made with planks (rather than using small trunks for walls) a chainsaw is required reflecting a higher household income. It is common for community members to borrow a chainsaw from one household that has made the economic investment for various reasons. Borrowing a chainsaw still requires money to buy gasoline and oil.

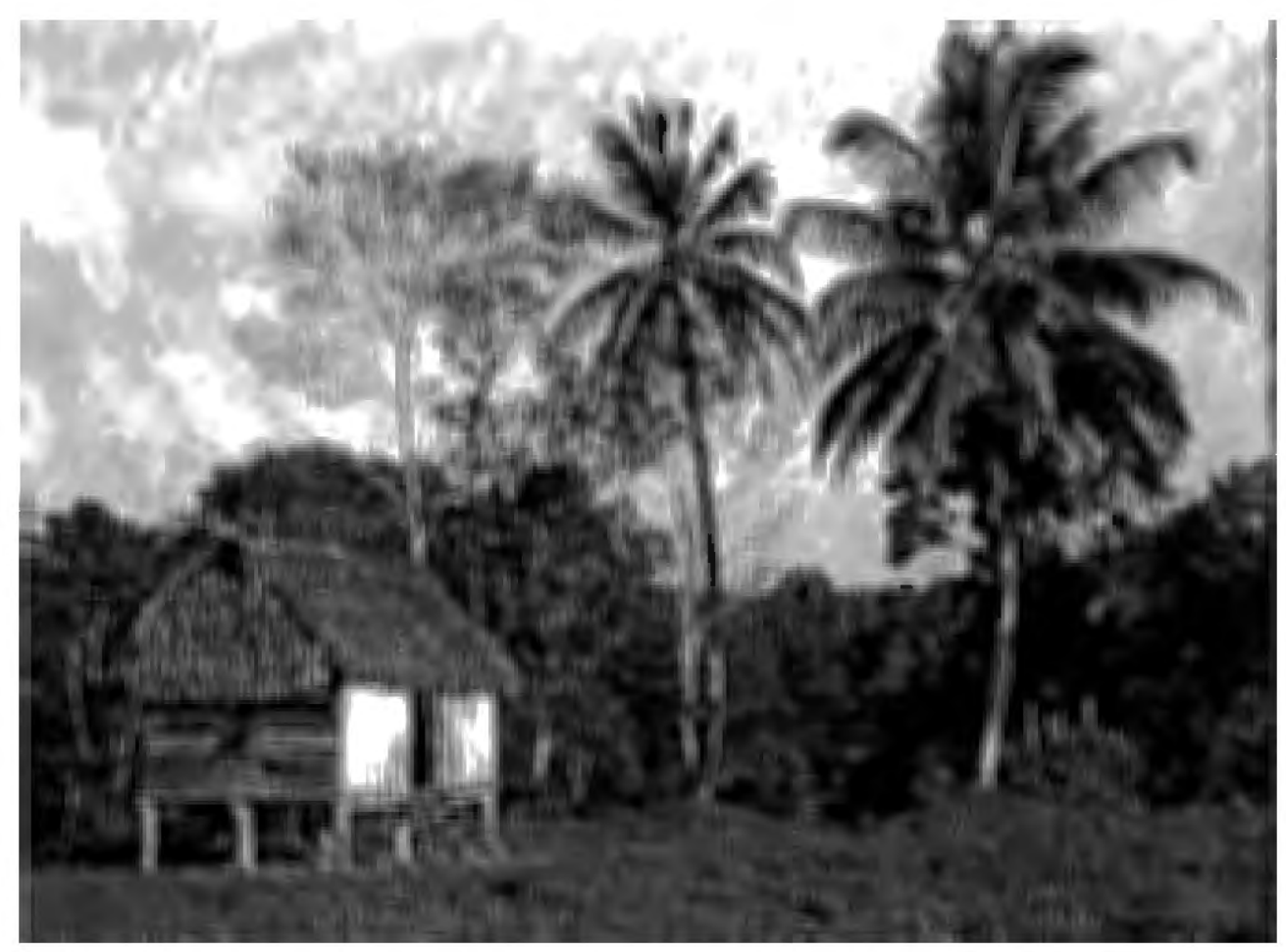

Figure 12. Traditional house on stilts

When income and time allows, houses are built with two structures, one for sleeping and one for cooking (Figure 13). The kitchen is ideally in a separate structure 
to keep insects and rodents out of the main sleeping area, as well as to reduce the heat and smoke in the main structure that is generated by cooking.

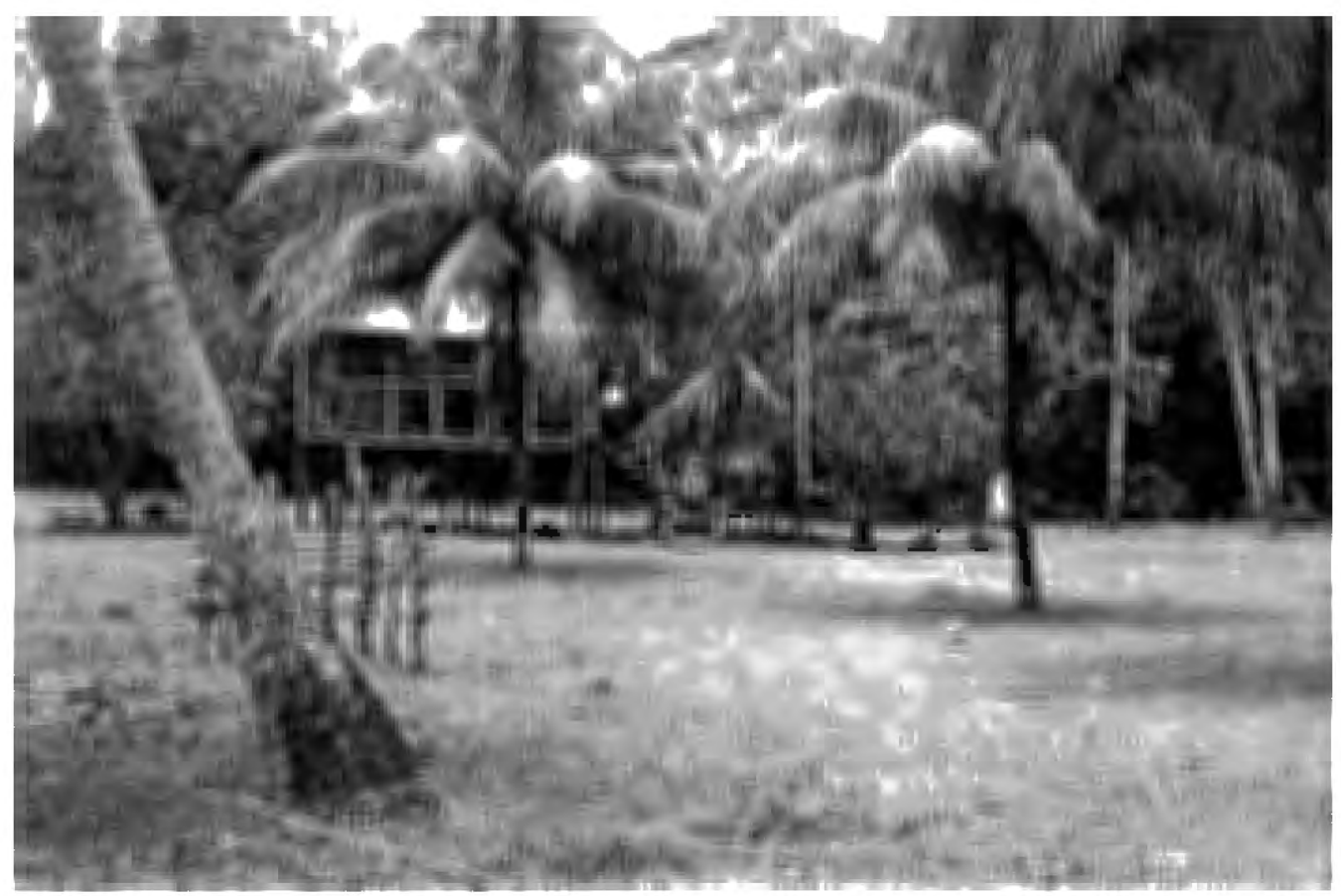

Figure 13. Separation of sleeping quarters (left) and kitchen (right)

The most durable trees, Cordia alliodora (Laurel), Calophyllum brasiliense (Santa Maria) and Swietenia macrophylla (Mahogany) are all used by over fifty percent of the participant population. Twelve participants reported that Cordia alliodora lasted an average of ten-years with a variance of five to thirty years, when used for house construction. Variance can be explained by the quality of the wood, as well as the quality of construction. Variance in the construction includes materials used to keep the woods together (nails or bihuko, a vine) and the part of the house that was constructed by the timber. Income influences the use of construction materials; 
households with higher incomes can afford to buy nails, which are more durable, rather than bihukos collected from the forests.

Calptrogyne sarapiquensis (Suita Palm), used by almost $80 \%$ of the population, is the most common palm used on thatched roofs (Figure 14). Elaeis spp. (Corozo Palm), also used for its fruits, is used for thatched roofs, although less often (Figure 15). Tin roofs are fairly new, more durable and require less maintenance than palm (Figure 16). On average, a palm roof needs replacement every five years, with some maintenance work each year. One household reported that they replace their Suita roof once every ten or fifteen years, while another reported a replacement every year. This varies depending on the construction of the roof, the spacing of the branches and quality of construction. The maintenance of a palm roof makes tin more desirable, but unlike palm, which can be found in the regions forests, tin must be purchased and transported. It is difficult to bring to the research area because of transportation issues. During dry seasons low streamflow in Banaka Creek makes it difficult for large canoes to carry a heavy load of materials. Once again, income influences which houseliolds use the more durable tin versus the work-intensive palm.

Population growth inside the study area, as well as on the coast, will have an impact on the abundance of trees in this tropical humid forest region. Since there are few trees available on the coast, where the majority of the reserve's population resides, it is common for people to travel down Banaka Creek in search of timber. Lupario Martinez of Banaka, town leader, president of the Ecotourism Committec, and former COHDEFOR employee, is fighting to restrict access to timber along the creek. Since 


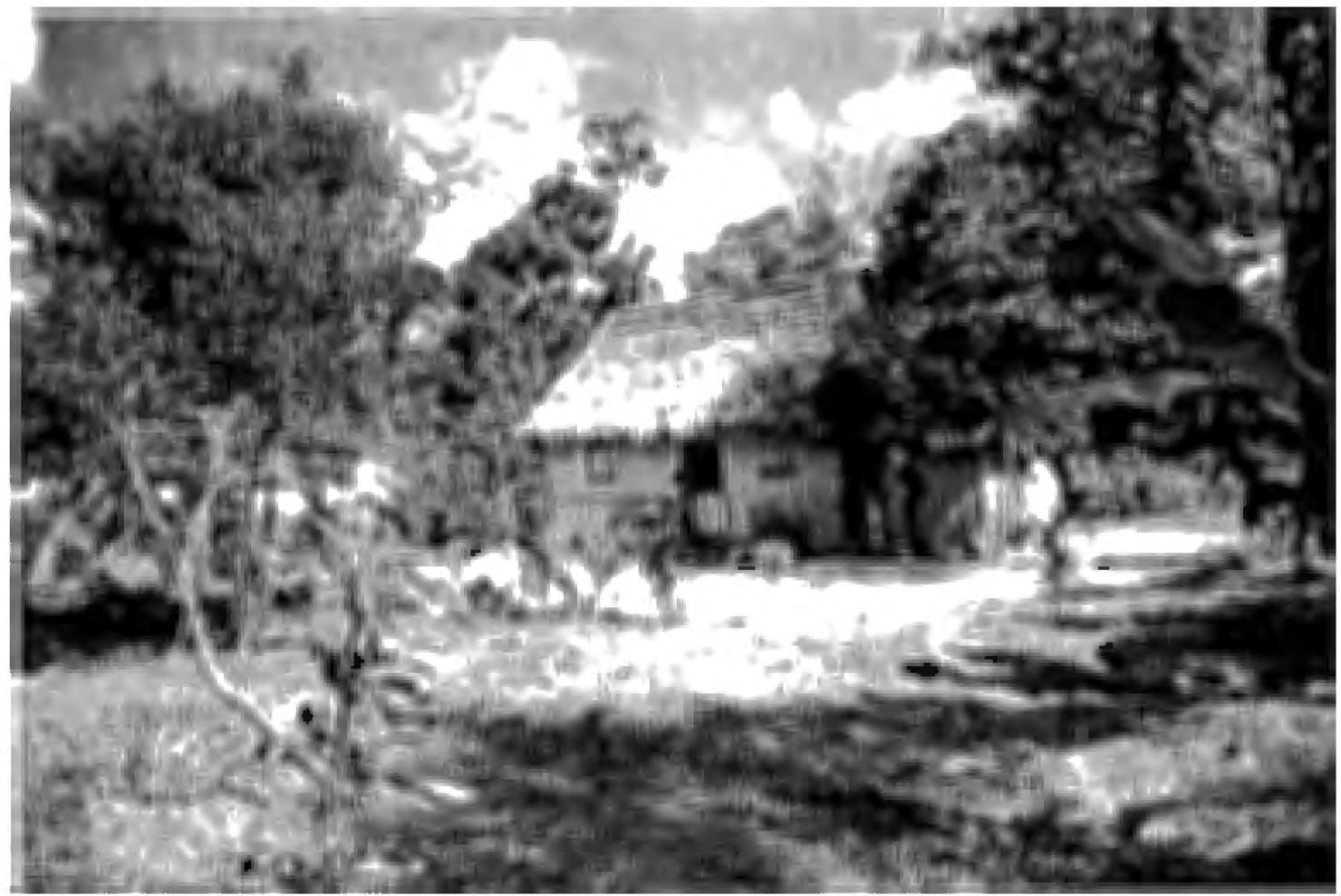

Figure 14. Traditional Calptrogyne sarapiquensis roof

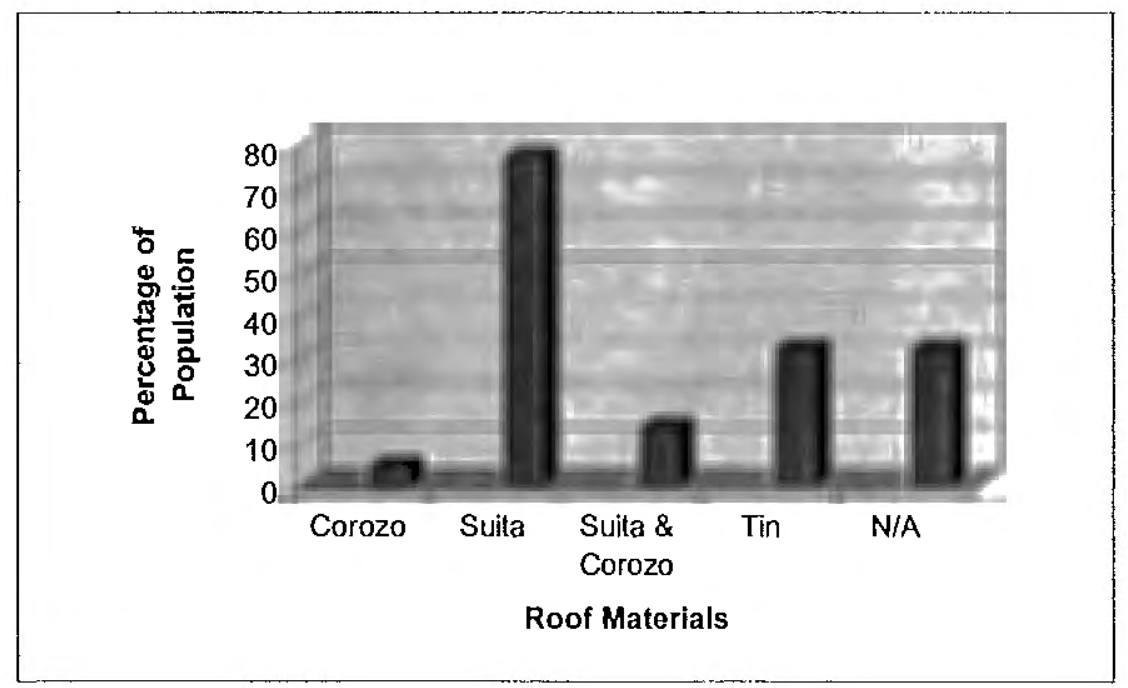

Figure 15. Roofing material used in research area 


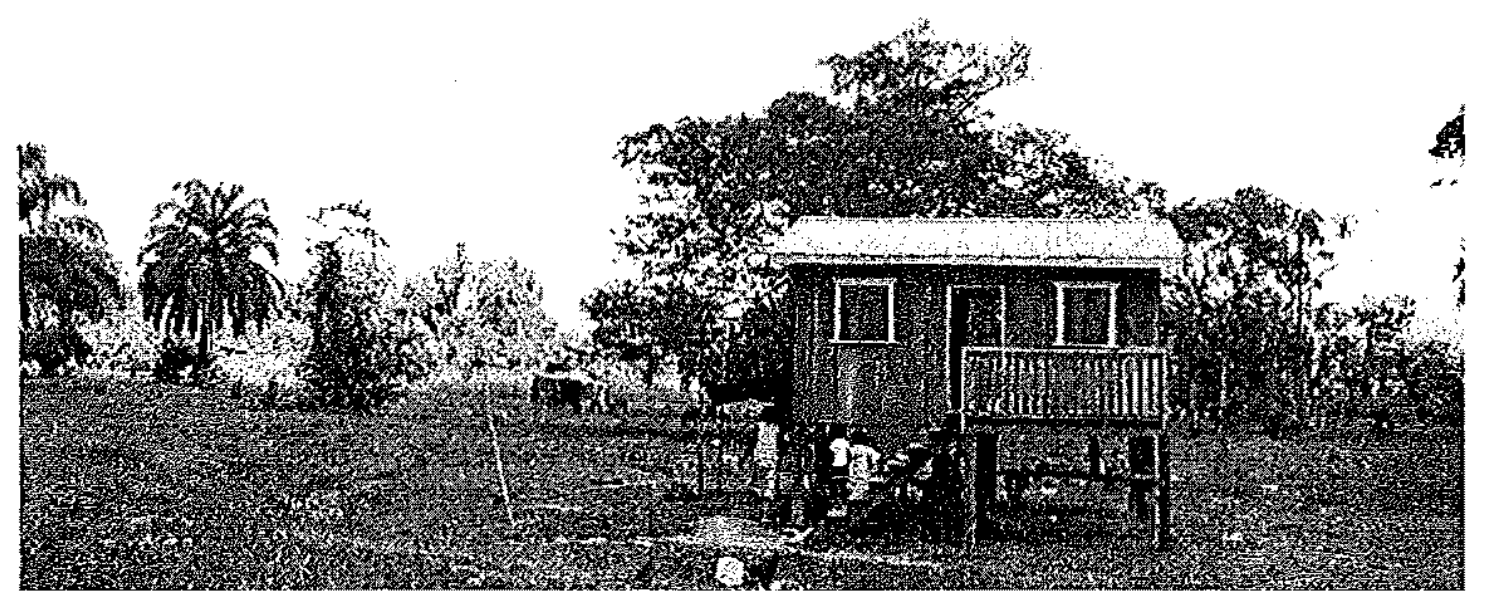

Figure 16. Traditional house with tin roof

population is greater and the presence of trees is less in coastal towns than in the interior region, demand for wood from coastal communities poses a threat to forest resources in the research area.

The primary forests in this interior forested region are isolated "islands" surrounded by agricultural lands and gwamiles. With the growing awareness of tree scarcity, the introduction of Inga edulis (discussed in Chapter Eight) and agroforestry concepts, and the increasing number of people who have begun to cultivate trees for future uses, it seems that tree-use may evolve into a system that depends less on access to primary forests and older native trees and nnore on cultivated species. 


\section{Hunting}

Hunting and fishing are subsistence activities in the study region and are dependent on the various forested regions. Hunting is mostly conducted in guamiles because of accessibility and presence of deer, armadillo, peccary and paca; the most commonly hunted animals. Fishing is practiced in the Banaka Creek, but has been on a constant decline since the settlement of coinmunities in the area and subsequent destruction of forests and ecosystems in riparian areas.

Meat from larger animals, such as deer, is typically distributed to community members. The system of distribution includes both sales and gifts of meat, depending on the kin and community relations of the member who shot the deer. Factors influencing the distribution system include the number of family members in the community, exchange for use of a gun or bullets, trade for other food products or necessities, or sale in the absence of a reciprocal relationship. The hunter and his immediate fanily consume smaller game. Guns are not common, so it is typical for a gun-owner to lend other comınunity members the weapon in exchange for meat when caught.

Terrestrial wildlife, such as puma, jaguar and peccary, is extremely rare in the lowlands of the communities. Forty or fifty years ago these animals were more common. Residents of this area still claim that large numbers of these wildlife are living in the hills. They believe they have been forced towards the hills, farther from settlements, as human population increase and glamiles replaced primary forests. Many animals, particularly large cats, have also fled human predation. This fear 
originated when jaguar and puma fur was desired from outside markets and hunting of these animals was rampant. Some residents believe that jaguar and puma populations have somewhat recovered, but it cannot be documented because of their tendency to stay away from humans and the lack of current faunal surveys.

Hunting linitations and regulations in the reserve are outlined in the Normas para el Manejo y Proteccion de los Recursos Natwal y Culturales handbook (AFECOHDEFOR et al. 2003). These regulations prohibit: hunting endangered animals, illegal traflicking of species, the use of humting dogs, hunting for commercial purposes, killing females nursing or carrying young, mass killings, sport hunting, hunting during closed seasons, hunting for reasons other than human consumption (with the exception of self defense), destroying hunting places, or hunting for people outside the influence of the reserve. Throughout the stay in the research area, the only observed infringement of these regulations was the presence of hunting dogs, however, they are expensive and uncommon. Additionally, guns are expensive and it is difficult to procure bullets.

As with the other forest resources in the reserve, habitats for terrestral and aquatic animals are affected by increasing human populations of the region and by increased competition for food and land. The restrictions outlined as part of the management plan for the reserve provide guidelines for the sustainable use of these forest resources. 


\section{CIIAPTER SIX}

\section{AGRICULTURAL RESOURCES}

In Banaka and the surrounding towns of Brans and Fuente de Jacob, agriculture and raising livestock are the most common forms of work and subsistence. Swidden agriculture is the main practice of this region, resulting in a landscape mosaic of active and fallow fields. The only community members not dependent on these forms of work are schoolteachers and church pastors. Agricultural resources include staple and supplemental crops, herbs, spices, medicinal plants and fruits grown in traditional agricultural fields, as well as in second growth gurmiles and dooryard gardens. The most common livestock found in the research area are cattle, horses, chickens and pigs; they are used for milk, meat, transportation and eggs. The agricultural resources and animals have been found in the research area for decades and are the core of subsistence and land-use.

\section{Cultivated Medicinal and Culinary Plants}

Medicinal and culinary plants, in addition to being gathered from forests, are also planted in solares (small kitchen or dooryard gardens), giramiles and agricultural plots. These cultivated plants play a significant role in medicinal and culinary uses; 
they have been chosen for cultivation because of their versatile uses and since they are conveniently located nearby to resident's homes, are used most frequently (Table 10).

TABLE 10

Cultivated Culinary and Medicinal Plants ${ }^{1}$

\begin{tabular}{|l|l|c|c|}
\hline \multicolumn{2}{|c|}{ CULTIVATED PLANTS } & $\%$ Culinary $^{2}$ & $\%$ Medicinal $^{2}$ \\
\hline Annatto & Bixa orellana & $58 \%$ & $48 \%$ \\
\hline Avocado & Persea mubigena & & 45 \\
\hline Basil & Ocimum campechiamum & 64 & 55 \\
\hline Cotton & Eossypium barbadense & & 3 \\
\hline Cacao & Theobroma cacao & 3 & \\
\hline Chili & Capsicum anmum & 64 & 55 \\
\hline Coconut & Cocos nucifera & 58 & 52 \\
\hline Cilantro & Eryngium carlinae & 76 & 58 \\
\hline Soursop & Annona muricata & & 48 \\
\hline Guava & Psidium guyava & & 52 \\
\hline Lemon & Citrus aurantifolia & & 36 \\
\hline Mango & Mangifera indica & & 39 \\
\hline Casherv & Anacardium occidentale & & 27 \\
\hline Ciruela & Prunus spp. & & \\
\hline Yaun & Dioscorea, spp. & 45 & \\
\hline Manioc & Manihot esculenta & & 52 \\
\hline Mamey & Pouferia mammosa & 52 & \\
\hline
\end{tabular}

${ }^{1}$ For a complete list of gathered and cultivated plants used in the research area see Appendix $C$. This list includes Spanish, English and Latin names.

${ }^{2}$ Numbers indicate $\%$ of sample population that uses plant for their culinary or medicinal purposes.

Some plants, such as Pouferia mammosa (mamey), are still found in primary forests and collected when encountered, but are more commonly cultivated. In the case of Pouferia mammosa, the diminishing tree numbers found in primary forests stems from unsustainable overexploitation. The Pouferia mammosa tree grows too tall to reach the fruit, so people chop down the entire tree to harvest the fruits and eventually the rate of reproduction could not keep up. The diminishing numbers of the Pouferia mammosa tree in the wild prompted its cultivation. 
The most frequently used plants are Evngiam carlinae (cilantro), Ocimum campechiantm (basil), Capsicum ammum (chili), and Cocos nucifera (coconut). Cocos nucifera is the most versatile; coconut water is used as a refreshing drink, to cook ricc or beans, or in a favolite Miskito drink, wabul, which is a sweet banana cooked and mashed with coconut water. The pulp of the Cocos mucifera can also be dried by roasting the coconut over a fire and used as seasoning in soups, cakes, and beans.

On the other hand, Theobroma cacao (cacao) is often planted in guamiles, which are not as accessible as solares and therefore are not as commonly used. It is cultivated by twenty-four percent of the participants, but not used for cooking. Because Theobroma cacao has a national and intermational market, it is possible that residents grow it with an intention to sell outside the reserve.

Each plant has multiple parts and methods of use. For trees such as the Mangifera indica (mango) and Prums spp. (ciruela), people use leaves and bark to make teas. Of the acknowledged remedies, many were taken for general well being; strengthening ones blood and heart, for stomach indigestion, and for a cough or coldlike symptoms. One example is Citrus atuantifolia (lemon). People eat lemons as a fruit or make lemonade regularly. Many other nedicinal plants were consumed as tea.

\section{Field Crops}

Survey respondents cultivate thirfeen different crops and sixteen fruit trees are planted (Table I 1). Principal staple crops include manioc, rice, beans, corn, and bananas, which are planted by over $90 \%$ of the population. $U_{p}$ to twenty varieties of 
TABLE 11

Plants Cultivated in Survey Respondents Gardens or Fields $(n=33)^{3}$

\begin{tabular}{|c|c|c|c|}
\hline \multicolumn{2}{|r|}{ Plant Crops } & \multirow{2}{*}{$\begin{array}{c}\text { Present in survey } \\
\text { gardens, \% } \\
97 \%\end{array}$} & \\
\hline Guineos & Musa spp & & \\
\hline Beans & Phaseolus spp. & 97 & \\
\hline Corn & Zea mays & 94 & \\
\hline Manioc & Manihot spp. & 91 & \\
\hline Rice & Oryza spp. & 91 & \\
\hline Taro & Colocasia spp. & 67 & \\
\hline Sweet Potato & Iponoea spp. & 55 & \\
\hline Sugar Cane & Saccharmm spp. & 48 & \\
\hline Pineapple & Ananas comosus & 30 & \\
\hline Potato & Solammin spp. & 24 & \\
\hline Pumpkin & Cumcubita pepo & 39 & \\
\hline Chili Pepper & Capsicum spp. & 24 & \\
\hline Sweet Pepper & Crupsicum spp. & 24 & \\
\hline Tomato & Lycopersicon spp. & 3 & \\
\hline \multicolumn{2}{|r|}{ Tree Crops } & $\begin{array}{c}\text { Present in survey } \\
\text { gardens, } \%\end{array}$ & $\begin{array}{l}\text { Average \# of } \\
\text { trees/household }\end{array}$ \\
\hline Coconut & Cocos nucifera & $79 \%$ & 8.4 \\
\hline Supa & Bactris gasipaes & 61 & 10.9 \\
\hline Mango & Mangifera indica & 58 & 2.5 \\
\hline Lemon & Cinns aurantifolia & 55 & 1.3 \\
\hline Breadfruit & Artocapus altilis & 48 & 2.4 \\
\hline Mamey & Pouferia mammosa & 45 & 1.6 \\
\hline Cashew & Anacardium occidentale & 42. & 0.5 \\
\hline Avocado & Persea nubigena & 42 & 4.3 \\
\hline Guava & Pisidium guayava & 36 & 2.2 \\
\hline Soursop & Ammona americana & 36 & 1.4 \\
\hline Orange & Citrus sinensis & 27 & 0.5 \\
\hline Cacao & Theobroma cacao & 24 & 4.5 \\
\hline Nance & Byrsonima crassifolia & 21 & 1.5 \\
\hline Ciruela & Prunus spp. & 18 & 0.9 \\
\hline Grapefruit & Citrus maxima & 15 & 1.5 \\
\hline Coffee & Coffea spp. & 6 & 1.5 \\
\hline
\end{tabular}

For a complete list of all agricultural crops cultivated in the research area see Appendix D. This list includes Spanish, English and Latin names. 
bananas and plantains are planted and are locally referred to as guineos. As a staple crop, new species are always being introduced. During the research period, one family hatvested "Guineo MOPAWI," a new species introduced by MOPAWI,

Other commonly planted crops are sweet potato, malanga, sugar cane, and potatoes. These are not staple crops but are typically used in soups and to add variety to the diet. Sugar cane, cultivated by almost half the population, is not processed in the research area; it is chewed, raw. Specific species for each crop were not obtained, but in 1983 Froelich and Schwerin identified nine varicties of manioc, nine varieties of local ginineos, four varieties of rice and three varieties of taro.

Only a few households cultivate tomatoes and peppers because of their vulnerability to pests. Insects, such as sampopos (leaf-cutter ants), persistently eat leaves of the plants and disturb fruiting opportunities (Figure I7). If grown at all, peppers and tomatoes are grown in solares rather than agricultural plots to better monitor and care for the crops.

Staple fruit trees include Cocos moifera, Artocarpts altilis, Cilms atrantifolia, Bactris gasipaes and Amanas comosus. As discussed in Chapter Four, Cocos nticifera are used for a variety of culinary purposes; it is commonly used because they can be harvested year round. Other fruits are seasonal and their lifespan is short. Sales and distribution of seasonal fruits depends on many factors, including household and family size, number of trees, and demand. When people visit family and friends, it is common for them to bring each other fruit gifts. It is common for 
residents of the region to take certain fruits, like pineapples, breadfiuits, avocados, zapotes, and cacao to the coast for sale.

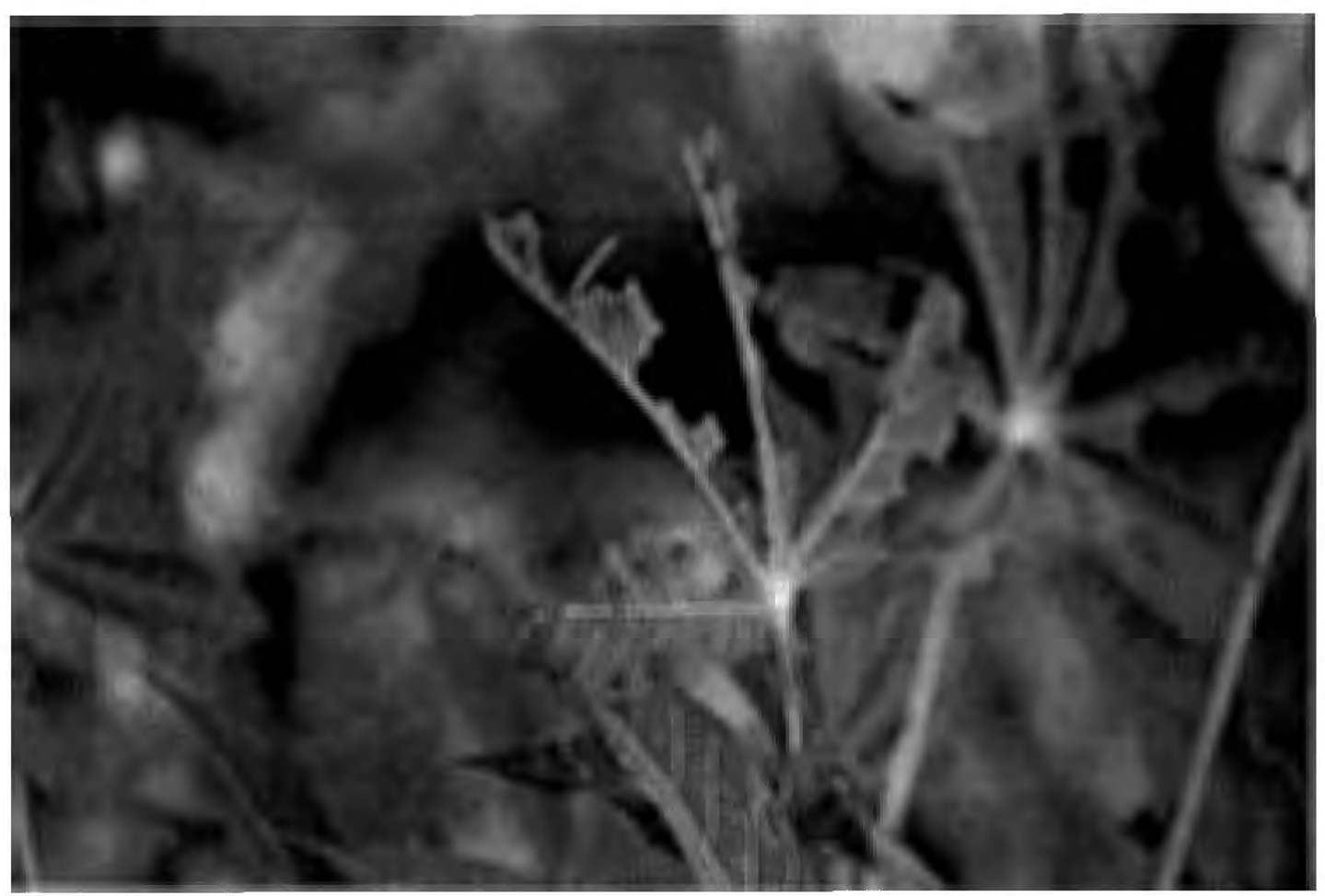

Figure 17. Sampopos on Manihot spp.

Almost $60 \%$ of households reported cultivating mango trees despite the fact that mangos, as well as ciruela, are commonly infested with sampopos and other insects and do not produce fruit in the research area. Residents use the leaves and bark of mango trees for other purposes, such as teas and medicines.

The results for coffee are misleading. Only one household cultivated coffee, but it had over 2,000 coffee plants. 2004 was the first year for the household to plant coffee so it has not yet yielded a harvest. Currently, coffee is purchased from outside 
resources, so they are excited about the prospect of being independent from outside sources for coffee.

\section{Characteristics of Agricultural plots}

Accarding to some preliminary data from Froelich and Schwerin, an average family needs about 3 manzanas ( 2.5 ha) per year to provide for its basic subsistence $(1983 ; 25)$. If a family allows a plot of land to fallow for 4 years, on average, then each family would need approximately 12 manzanas (10 ha) of land to farm. Froelicl and Schiverin also estimated that with population size and available land along the Rio Plátano and Baltiluk Creek that there appeared to be sufficient cropland to support the population at the time of the study (1983), as well as anticipated populations of the reserve without an impact on the nucleus zone. Their estimates of population growth did not include the unexpected influx from migrants from other parts of Honduras.

The amount of land cultivated in the research area ranges from one to fifty manzanas $(1$ manzana $=$ approximately $0.8 \mathrm{ha})$ and one to $1000 \mathrm{~s}$ of fruit trees. Twenty-five households knew the approxinate amount of land their family worked -an average of 13.44 manzanas of land (Table 12). David Dodds found that when residents of Belen (a Miskito coastal town) gave estimations for their agricultural plot sizes, the size of small plots were underestimated by interviewees, while the size of large plots were overestimated $(1994 ; 248)$. The results of Dodds' measurements serve as a base in this thesis for the estimations given by survey respondents. It is 
likely that respondents provided estimations that reflect a similar under or over estimation based on the size of their plot.

TABLE 12

Agricultural Field Size (in Manzanas) as Reported by Residents

\begin{tabular}{|c|c|c|}
\hline & $\begin{array}{c}\text { Number of } \\
\text { households } \\
\mathrm{N}=33\end{array}$ & $\begin{array}{c}\text { Percentage of } \\
\text { households } \\
\mathrm{N}=33\end{array}$ \\
\hline N/A & 8 & $24 \%$ \\
\hline$>5$ & 6 & 18 \\
\hline $5-10$ & 10 & 30 \\
\hline $11-15$ & 3 & 9 \\
\hline $16-20$ & 1 & 3 \\
\hline$<20$ & 5 & 15 \\
\hline
\end{tabular}

The distance people travel to their agricultural plots greatly influences the cultural landscape of the region. It is typical in Brans and Fuente for houses to be dispersed and surrounded by pasture and agricultural land (Figure 10). On the other hand, Banaka is a centralized community and residents commonly traveled some distance to their agricultural field. Some Banakan residents live adentro (away from the centralized part of town), where the landscape is more similar to Brans and Fuente and for this reason have agricultural plots closer to their homes. On average Banaka residents traveled thirty minutes to their fields; Brans residents eleven minutes; and Fuente de Jacob residents, eighteen minutes. In general, residents of Brans and Fuente de Jacob travel shorter distances and people in Banaka tend to travel farther distances to reach their agricultural plots. 
One matter in agricultural practices of this region is the number of years households work and fallow their lands, The majority of patticipants work their agricultural lands anywhere between one to three years, while letting them go fallow for three to six years. There are few differences between community and ethnicity for this particular issue, nor is there a relationship between the number of years land is worked/fallowed and the anount of land that one has. For example, participants who work their land for five to six years, have between ten and twenty-three manzanas. Conversely, households that only work their land one year have between one and fifty manzanas. The inconsistency of responses throughout the region can be attributed to a variety of reasons, including the productivity of the land or even possibly the presence of MOPAWI and practices they emphasize in their educational information.

Eighteen participant households reported selling agricultural goods to coastal communities when there is a surplus. The demand for goods fiom the research area and coastal conmunities suggests that if population size were to increase so would the demand for agriculture, thus placing greater demand on agriculture land in the research area. Transportation difficulties, large family sizes, and little surplus limits the ability of residents of this area to participate in large-scale commerce. At the same time, there is linited income from wage labor and it becomes necessary to sell or trade goods to get other essentials such as shoes, clothing, soap and other products that eannot be found in the forests. 


\section{Livestock}

Livestock in the research area includes cows, horses, chickens, ducks, geese, pigs, and goats. Cattle have the most impact on land-use; forests are cut down to make grazing lands, their feces pollute the creek, and they creatc erosion along riparian zones. To avoid some negative impacts created by pigs, many residents pierced a wire through the pigs' nostril to prevent them from rooting through the soil. The presences of ducks, geese and chickens have a minimal impact on the land.

The presence of cattle is controversial within the limits of the reserve. It is commonly believed that Ladinos migrate to the reserve specifically to gain profits by cattle raising rather than for subsistence. The reserve has a relative low population compared to the rest of the country and large amounts of "un-used" land that attracts landless Ladinos trying to make a life for themselves and family. This migration of Ladinos is especially apparent in the southwestem comer of the reserve where road development is naking it easier for people to entcr the reserve. The influx of Ladinos on traditional Miskito lands causes conflicts between the two ethnic groups; Miskitos believe the reserves' regulations are restricting their land-use based on Ladino tendencies to have more cattle. Reserve regulations pernit cattle for both personal and small-scale commercial use in different laud-use zones (cultural and buffer zones, respectively). These regulations include: supervised burning of guamiles for pastureland, restriction of planting new pastures in specified areas, restriction of freeranging cattle in agricultural lands, restriction of chemical use, and liniting impacts of riparian zones and other areas under special protection. In the research area livestock 
numbers vary by ethnicity; on average, Ladinos have more cows, pigs, and chickens, than their Miskito neighbors (Table 13).

TABLE 13

Average Number of Household Animals, by Ethnicity

\begin{tabular}{|l|c|c|c|c|c|c|}
\hline & Cows & Horses & Pigs & Chickens & Ducks & Geese \\
\hline Ladino & $3.9^{*}$ & 1.8 & 2.3 & 10.2 & 0.1 & 0.2 \\
\hline Miskito & 0.8 & 0.7 & 0.5 & 7.4 & 0.3 & 0 \\
\hline
\end{tabular}

* The actual average is estimated between 4 and 5 .

Residents of Fuente de Jacob, a predominantly Ladino town, report a significantly higher number of cows on average than the other communities (Table 14). The typical Ladino settlement pattern is dispersed with houses surrounded by pastureland and agricultural plots, which makes it easier to maintain cattle. Brans has a similar spatial arrangement to Fuente but did not report having as many cattle.

TABLE 14

Average Number of Household Animals, by Community

\begin{tabular}{|l|c|c|c|c|c|c|}
\hline Community & Cows & Horses & Pigs & Chickens & Ducks & Geese \\
\hline Banaka & 1.3 & 1.1 & 0.6 & 6.6 & 0.2 & 0 \\
\hline Brans & $2^{*}$ & 1.2 & 1.6 & 13.2 & 0.4 & 0.6 \\
\hline Fuente de Jacob & 7.4 & 2 & 4.4 & 14 & 0 & 0 \\
\hline
\end{tabular}

* The actual average is estimated between 4 and 5 .

One possible explanation for the difference between Fuente and Brans is the variance in data collection for the two communities. A resident of Fuente, trained as a research assistant, conducted the formal interviews in Fuente. Conversely, I 
conducted the formal interviews in Brans with the presence of Lupario Martinez, Banaka town leader and former COHDEFOR employee. The sensitive issues surrounding cattle and clearing forests for pastureland and the presence of a foreigner and COHDEFOR employee may have influenced participants' response. For example, one Brans household reported having two cows, meanwhile more cattle were observed grazing on their property during the interview. 


\section{CHAPTER SEVEN}

\section{ECOTOURISM}

Since the Río Plátano Biosphere Reserve vas designated as a protected area, land pressures from the southern and western boundaries (Olancho and Río Sico, respectively) have been a major concern (Froelich and Schwerin 1983; 42). Those pressures include cutting forests for timber resources as well as increasing pasture areas for livestock grazing. Introduction of a cash econony and the resulting influx of outside material goods increases desires for amenities of a modern lifestyle including higher incomes and improved schools, health care, housing, communication and transportation. Access to these amenities can be obtained by exploiting forest resources in the reserve or through the establishment of a cash eaning ccotourism industry.

Ecotourism devetopment in the reserve emerged as a solution to the ongoing conflict between conservation efforts and the economic needs of local populations. With increasing pressures to exploit forests and their resources and the lack of cash eaming activities, ecotourism development is promoted and supported by involved international, national, and local organizations. If reserve residents can generate an alternative income from ecotoutism, they have an incentive to protect forests and more options for procuring outside goods; thus, presumably forest resource extraction would 
decrease and land-use practices would focus on conservation of forests to attract visitors.

An ecotourism visitors guide has been created for the Río Plátano Biosphere Reserve to outline expectations and guidelines for visitors. It provides a cultural, historical, and biological sumunary of the reserve; describes the logistics for transportation, lodging, food, and guide services; and highlights the reserve's ecotourism destinations. MOPAWI, USAID, PROARCA, Peace Corps, and the Central American Commnission of the Environment and Development, all provided support for its publication. The guide can be purchased through MOPAWI or at various reserve hospedajes (locally-1un lodging). The reserve's accepted definition of ccotourism is "the practice of developing and managing nature based tourism that provides outstanding opportunities for visitors in a healthy, natural setting while minimizing negative impacts to natural ecosystems and local culture. It must also help sustain the protection and management of parks, reserves and natural areas as well as contribute to sustainable economic development for local communities (Macomber et al. N.d.; 5)." There is an emphasis on ecotourism as both tourism with a nature focus and a philosophy of managing nature-based tourism in a way that contributes to the protection and management of the reserve and its natural and cultural resources.

\section{Ecotourism in the RPBR}

The reserve's remote location makes travel difficult and expensive. A flight from La Cieba to Palacios costs approximately $\$ 100$ USD. A flight is the most direct 
option, but it is possible to find a freight boat allowing passengers for a fee, or to take a combination car/boat ride from La Ceiba. Travel within the reserve is mostly limited to boat and foot, although along the coast an unimproved road supports occasional truck transportation.

Ecotourism destinations are established in Palacios, Rais Ta, Las Marias, Plaplaya, Río Plátano, Belen and Kuri (Figure 8). These communities, with the exception of Río Plátano, all have a hospedaje that offer meals at an additional cost or have a nearby comedor (locally-run restaurant). The accommodations are rustic; they offer shared slecping quarters, outside latrines, and bucket bath facilities. Provisions, if provided at all, vary; some possible provisions include a mosquito net, candles, toilet paper, drinking water or an electric light. In Rais Ta, the hospedaje procured a solar panel in July 2004 and now provides an electrical light for their guests in both the sleeping quarters and comedor.

The Las Marias community has a long history of accepting and guiding tourists through forests surrounding the small Pech town of approximately 500 people (Herlihy 1997). The community of Las Marias, located about ten kilometers up the Rio Plátano, operates community-based ecotourism. Each conmunity member parlicipates in some nuanner, either as a guide, ruming a hospedaje or comedor, transporting people in canoes, or by simply abiding by the community established nules to preserve the area for visitors. Seven tours are offered in Las Marias, ranging anywhere from a strentous three-day jungle hike, to an easy three-hour like along the 
Río Plátano. The community also provides services for people vacationing with an adventure travel company from outside the reserve.

As a community, the people of Las Marias established a Guides Association committee to solve tourism related problems, increase and equitably share incone from tourism and to improve services provided by tourists guides (Appendix E). Additionally, the community has established Norms and Regulations of Tourism in Las Marias. This document outlines logistics for guides; prices for guides, boats, meals, and rooms; tourist norms and regulations; and guide noms and regulations (Appendix E). These noms and regulations are posted throughout the village for visitors.

Conversely, in the town of Rais Ta, there are no noms or regulations in writing about the praetices of their tourism operations, although prices are set and well known. One local family, the Boddens, runs the hospedaje, comedor, butterfly farm and motorboat service - all the services offered in Rais Ta. The entrepreneurial success of the Bodden family has created resentment by other community members who do not receive any benefits.

These two contrasting approaches to ecotourism are both possible in Banaka although the majority of town members prefer a eommunity-based system, similar to the one in Las Marias. In general, communily-based ecotourism is preferred because it equally benefits all community members interested in participating. It empowers communities to invest in their town and allows each member freedom to participate 
hovever they are able or willing. Conversely, when only one family benefits there is resentment from the comnunity and a lack of cooperation in ensuring success.

If the rationale for supporting ecotourism is to promote conservation of the area's forest resources by linking it to economic benefits, coopcration from the entire community is necessary. If only a portion of the community receives economic benefits, it will only be that portion of the population that cooperates in maintaining forests and surrounding ecotourism sites. Community members receiving no economic benefit from ecotourism will continue to access those forest resources to receive economic gains in another manner. The promotion of ecotourism in the reserve from intemational, national and regional agencies stems from the potential for residents to receive an income that provides an alternative to extracting and exploiting forest resources as an income source.

\section{Ecotourism Demand}

A typical Río Plátano Biosphere Reserve tourist is seeking adventure, accepting of rustic accommodations, and interested in indigenous cultures, as well as biological and ecological diversity (Nielsen 1995; 72). The demand for ecotourisin in Banaka can be estimated by comparison with Las Marias (Nielsen 1995; BoxerMacomber et al. 1997). From Rais Ta, a stopping off point for visitors between Palacios and other communities in the reserve, Las Marias is a six to eight hour canoe ride up river. Las Marias began guiding tourists in the early 1990s and now has wellestablished accommodations and visitor regulations. Information from the established 
ecotourism operations of Las Marias, a town of similar biological and ecological resourees to Banaka, provides a basis for estimating visitor demand.

One advantage Banaka has over Las Marias is that Rais Ta is only a four-hour cance ride away, One disadvantage is the community's inexperience accommodating ecotourists and its lack of community organization. The attractions in both areas are similar, with primary forests that are home to a variety of primates and birds, petrogylphs, and general nature hikes. 'To date Banaka still lacks trail nuaintenance and development, community involvement and cooperation, basic housing and eating accommodations for guests, training guides, and a system for having surplus food available upon visitors' arrival. Las Marias, with nearly fifteen years of ecolourisn experience, serves as a model for Banaka.

Despite the current differences, visitor information for Las Marias in the late 1990 s (after almost a decade of experience) provides a general understanding of visitation in this region. In $1997^{1}$ approximately 300 visitors went to Las Marias. On average there were thirty visitors per month, an increase from twenty-six per month from the year before. The majority of visitors came between February and May, the longer dry season; they were between the ages of twenty and thirty-nine, classified as professionals, and came from Europe, North America, Central America, Australia, Israel, Colombia, New Zealand, and Japan. These figures reflect interest for naturebased tourism in the reserve.

\footnotetext{
'The following information on Las Marias is obtained from Boxer-Maconber ef al., 1997 Informe Ammial del Ecotourismo, published by MOPAWI and other supporting organizations. Data Was compiled from ecotonisin shdies conducted in Las Marias and from visitor books belonging to Las Marias Ecotourism Conmittce.
} 
In 1997 Las Marias made \$193,459 Lempiras from ecotourism. At the current exchange rate of 18 Lempiras to $1 \mathrm{USD}$, that is approximately $\$ 10,747$ USD. This income in Banaka, which currently has limited cash generation, could increase the standard of living for community members. It could also generate conflicts and tension between community members. Over the last decade, Las Marias has established conmunity standards limiting arguments over income distribution. Banaka community members are excited about ecotourism and the opportunities it can bring, but nobody expressed any concern about possible income conflicts that may arise.

Figures froin Las Marias demonstrate a demand for ecotourism in the reserve. The proximity of Banaka to Rais Ta and the ecological, cultural, and archeological resources of the region offer visitors the nature-based adventures they are seeking. There is potential for Banaka as an ecotourism destination, yet many issues surrounding the accommodation of guests need to be addressed.

\section{Ecotourism Potential and Resident Perspectives}

The general consensus in the study area is that ecotourism in Banaka would greatly benefit both people and environment. The main problem identified by residents is a lack of organization. Lupario Martines, Banaka town leader, introduced the idea of bringing ecotourism to the community. He worked for COHDEFOR for seven years and resigned during the research period specifically to focus on bringing the community together and getting ecotourism established. On June 23, 2004 a 
meeting was held to discuss ecotourism possibilities, advantages and disadvantages of proposed sites, and to form an Ecotourism Committee. Only four community members, all men, attended the meeting (Appendix B). Residents are anxious for an ecotourism boom (yet another "boom" economy to enter the reserve) although few are involved in the process of attracting and establishing accommodations for tourists.

Banaka town center has two main areas, abajo and antiba (meaning dowvin river and up river, respectively). The proposed site for Banaka's hospedije and comedor is located arriba. This location is controversial because community members living abajo feel excluded (Figure 18). Lupario Martines, being the project initiator, chose this location because it is on his family land and he could begin working on it without any delay. Lupario and a ferv other community members have previously established an Ecotourism Committee and sought funds from various sources. This Ecotourism Committee does not include members representing both sides of town and actions in pursuing the haspedaje site have led to further division within the community.

A proposal submitted to MOPAWI requested a loan to buy materials to complete the hosperlaje and comedor, as well as to furnish those two buildings (Appendix F). A large funding source, available through Rare, a U.S. based conservation organization, fell through in January 2004 when a representative came to Banaka and nobody involved in the project was available to talk with him, show him the site or their progress. Rare provides support to grassroot conservation programs with training and technical support. This $\$ 30,000$ USD grant was awarded to eight other communities in the reserve. 


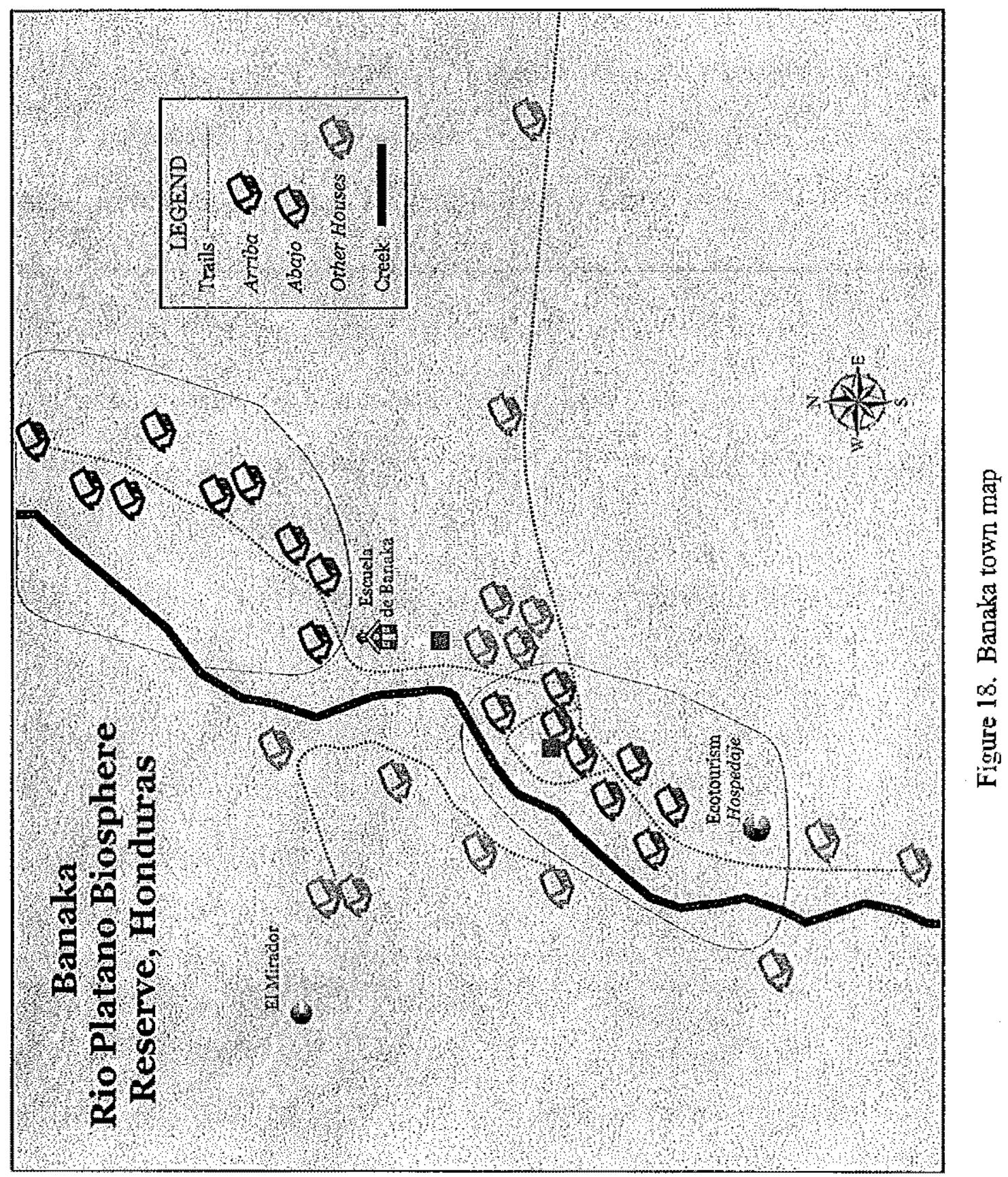


Prior to the loss of Rare funding, Banaka sent two local representatives to receive tourism business training in La Ceiba through them. To date, the Ecotourism Committee has also cleared an area for building a hospedaje and comedor, identified destinations for tourists (Figure 19 and 20), starting clearing trails and viewpoints, and started building the hospedaje (Figure 21 and 22). Of the two representatives that went to La Ceiba for training, one never returned and the other (who lives in Fuente de Jacob) became frustrated with the situation after the loss of the Rare grant and limited his involvement. The intention of Rare training is for representatives to retum and share their education with the community; this was not achieved in Banaka.

Banaka as a community has started preparing for ecotourists but considerable work still lies ahead. The largest problem, apparent to outside observers and acknowledged by community inembers, is a lack of cooperation and organization among communities of the region. For example, a system for trail maintenance between towns does not exist. These trails will be used to reach viewpoints and petroglyphs during ecotourist visits. During the rainy seasons horse traffic on these trails creates massive mud puddles and makes it difficult for foot travel. Rubber boots are essential and nud can be kıee-deep and very slippery. Eliminating or mimimizing this problem would require the cooperation of everybody who traveled on those trails and a designated system for separate horse and luman trails. 


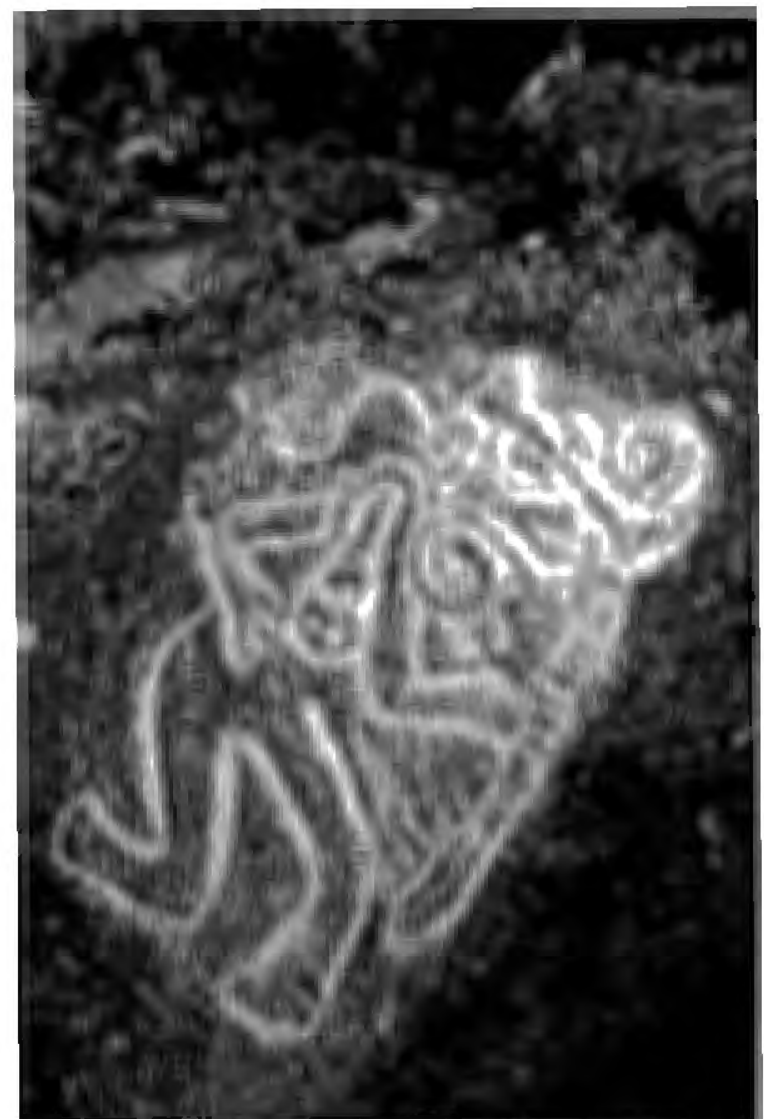

Figure 19. Banaka ecotourism destination, petroglyphs

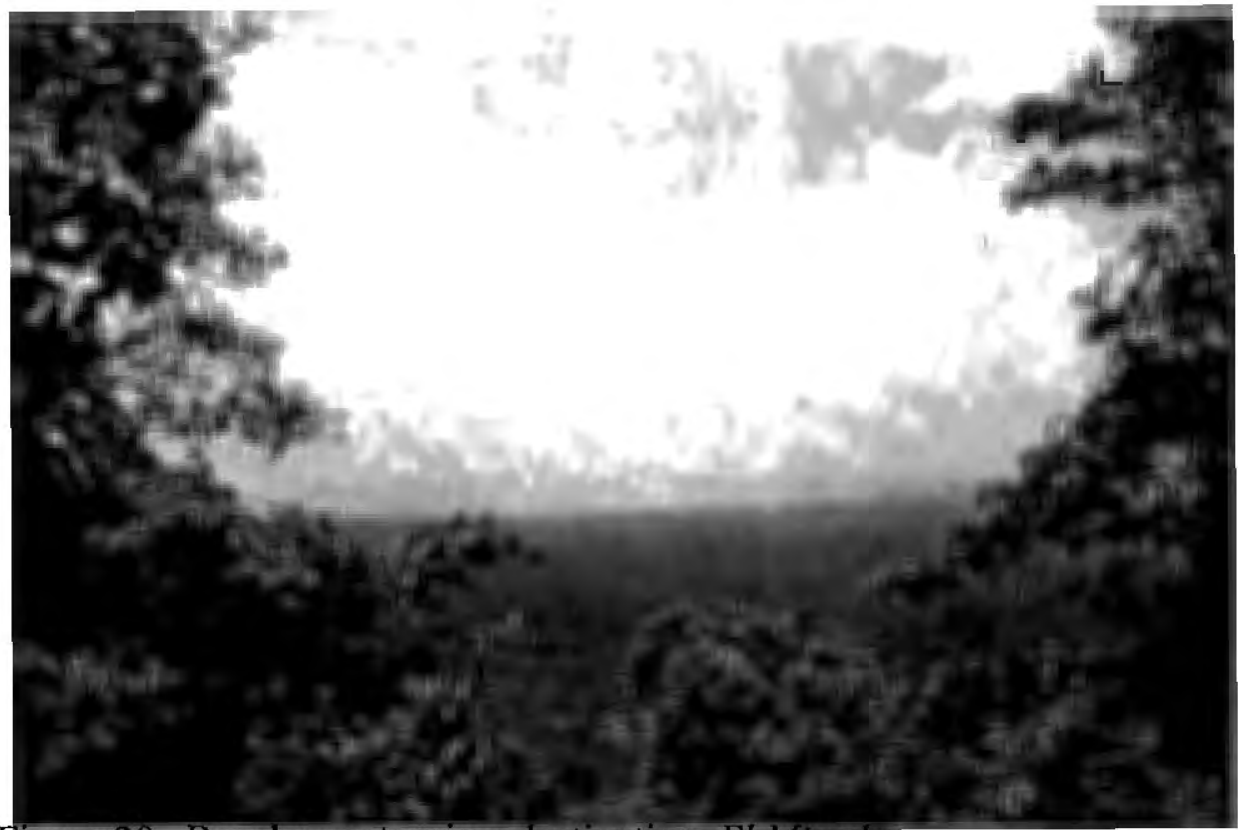

Figure 20. Banaka ecotourism destination, Et Mirador 


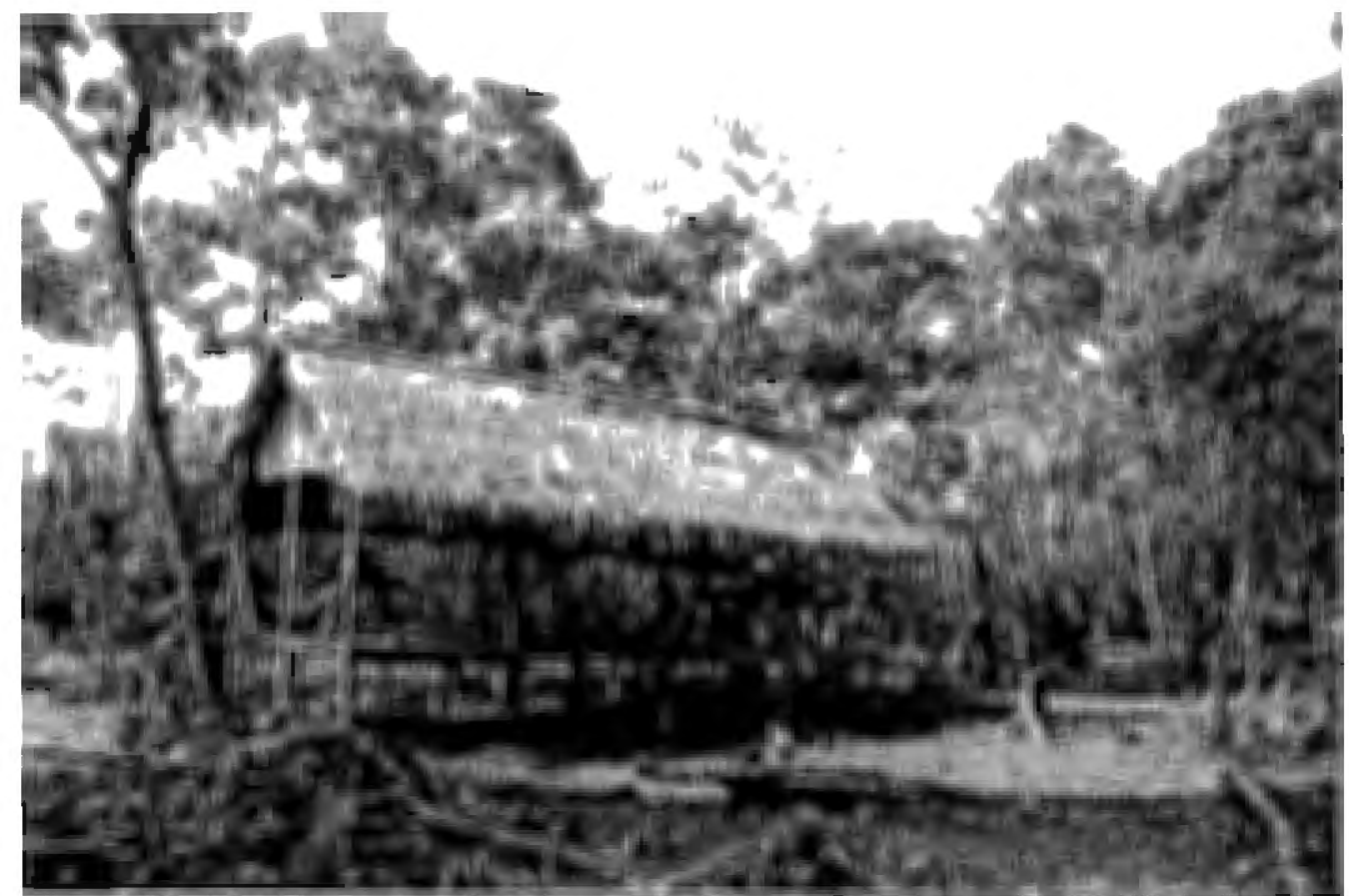

Figure 21. Banaka ecotourism hospedaje

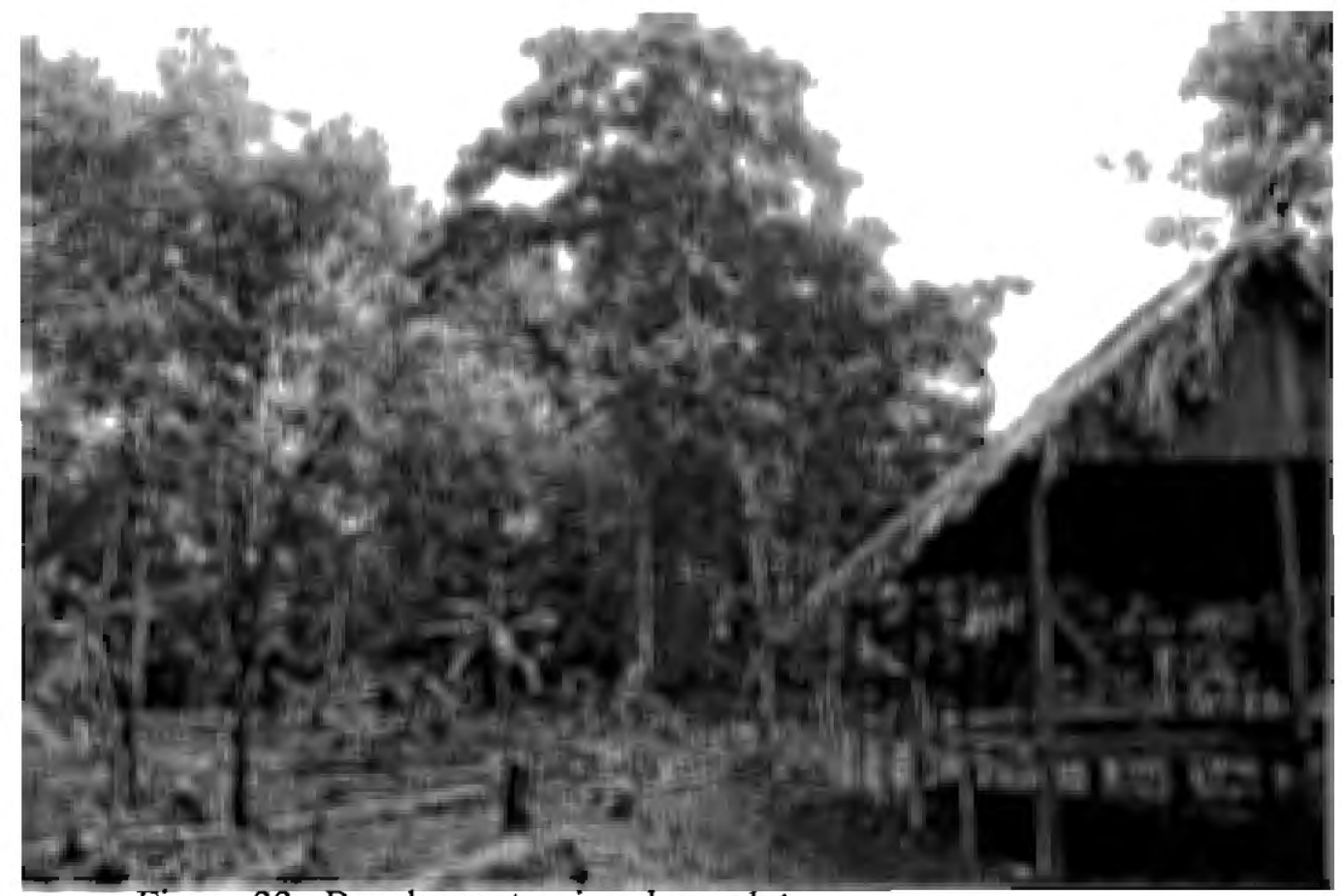

Figure 22. Banaka ecotourism hospedaje 
Every research participant mentioned the enormous economic benefit of bringing ecotourism to Banaka. Even those who are uninformed about specifics of ecotourism understood that it could bring economic success. Only one person mentioned a negative outcome of regularly inviting or hosting visitors - changes in their daily lifestyles would have to be made to accommodate visitors. This would include having showers as opposed to bathing in the creek; providing a variety of food that is unavailable in the region; preparing food differently than they prepare it for themselves; having outhouses; and keeping farm animals separately from housing.

The manner in which community members are willing or interested in participating in ecotourism is split based on gender. Women were interested in cooking, cleaning, and maintaining glest rooms by washing sheets and dishes, making beds, and properly caring for guests. Alternately, men are interested in guiding guests on hikes and providing canoe transportation.

Despite high interest in participating and getting involved, only six people are involved with the Ecotourism Committee. Lupario Martines organized a day to clear land at an ecotonrism destination viewpoint for better visibility and to allow sunlight in to discourage rampant mosquitoes, and only four community members showed up. Additionally, when Lupario organized a second clearing round at the hospedaje site, seven people started and four more shoved up later in the day. The lack of high participation in these organized events demonstrate the lack of community organization and cooperation. 
In 2003, Nielson et al. found that community-based ecotourism in the reserve resulted in the improvement in community capacity to develop ecotourism initiatives to increase biodiversity conservation, such as sea turtle conservation projects in the town of Plaplaya. They also found that the increase in disposable income could result in access to more efficient technologies, improved access to education, health care, family planning and material well-being. Since completion of fieldwork in Banaka in July 2004, meetings have increased and cooperation between arriba and abajo is also increasing (Personal communication with Steve and Jude Collins, Tear Fund). A price list was established; an advertisement flyer was made; logistics for bringing visitors to Banaka from Rais Ta are being worked out; and the overall effort to get things started has increased. If cooperation and participation in bringing ecotourism to Banaka continues to increase, the opportunity for success in conserving the areas' forest resources, improving their daily lifestyles and providing economic opportunities, also has the potential to increase. 


\section{CHAPTER EIGHT}

\section{DISCUSSION AND CONCLUDING REMARKS}

The subsistence-based societies of Banaka, Brans, and Fuente de Jacob all face an on-going conflict between conservation and economic development. Vast forest resources and land surrounding these communities can be easily converted for agriculture, cattle grazing and other casl earning products or opportunities. As a

result, international organizations such as The Nature Conservancy, USAID, UNESCO, Rare, and IUCN; national organizations such as AFE/COHDEFOR, DAPVS, and BRP; and local organizations like MOPAWI, are promoting ecotourism as a solution for conserving surrounding forests and providing economic development opportunities in the area.

Different approaches to conservation in protected areas have lead to the introduction of the biosphere reserve model and the use of ecotourism as a catalyst for protecting natural resources. Each protected area uses unique methods for delineating land-use zones, establishing and managing the park, and conservation strategies. The biosphere reserve model, although the focus of this thesis, is not the only model to include local residents in conservation. The Beni Biosphere Reservc (discussed in Chapter Two) was initiated by the efforts of national and intemational organizations 
and set out to educate and inforn local residents of the proper practices for meeting conservation goals; using a top-down approach. The strategy used by the Corcovado and Piedras Balances National Parks in Costa Rica (discussed in Chapter Two) demonstrates that conservation increases when local residents receive economic benefits directly related to ecotourism. The RPBR is being encouraged to use a community-based ecotourism strategy to increase conservation and increase potential economic development.

In general, the purpose of protecting natural areas is for biodiversity, wildemess, ecosystems, natural features, landscapes/seascapes, sustainable use of natural systenis, or habitat and species. The approach taken to conserve and manage parks influences the environnental impact, changes in land-use and cover, and natural resource use. Studies on the approaches of protected areas and uses of ecotourism (discussed in Chapter Two) demonstrate that several outcomes are possible. The investigation of influential factors and documentation of current practices specific to the RPBR, can help to establish a system for conserving both the cultural and biological diversity, and provide economic and social benefits to local populations.

I doeumented current forest resource and land use practices in the larger Banaka region, identified factors that influence resource extraction, and examined the role of ecotouism in the region. A geographic perspective entphasizing interactions between humans and their environment provided the context for examining conservation within protected areas, the Man and Biosphere model; traditional resource namagenient and land-use, and ecotourism in scveral communities of the 
Honduran Mosquitia. Physical, social and political geography influence how indigenous and Ladino populations in the RPBR interact with the surrounding environment.

This chapter concludes the story with analysis on ethnic, community and gender comparisons; an examination of influences from outside source of incomes; documentation of residents' perspectives on park regulations; and identifying new prograns used to promote conservation in the reserve, such as agroforestry and ccotourism. Conducting this research in the initial stages of ecotourism development provides base information for future research on the effects of the industry and to determine any changes in forest resource and land-use, and changes in the protection and conservation of resources.

\section{Overview on Forest Resource Use}

A comprehensive documentation of forcst resource use in three comnunities of this region of the reserve provides data on what plants and trees are being used, how they are being used, and approxinately how often they are being used. Forest resource use in this region continues to evolve and change. Introduction of alternative sources of income, such as ecotourism, will enable residents to purchase outside goods and will influence the use of forest resources of this region. Documentation of natural resource use at different points in time is important for the evolving reserve management and for conservation of the biological and cultural resources in the rescrve. 
Despite initial presumptions of this research there was little variation in plant use between Ladino and Miskito participants (Table 15). This can be attributed to the

TABLE 15

Plant Use in the Banaka Region, by Ethnicity

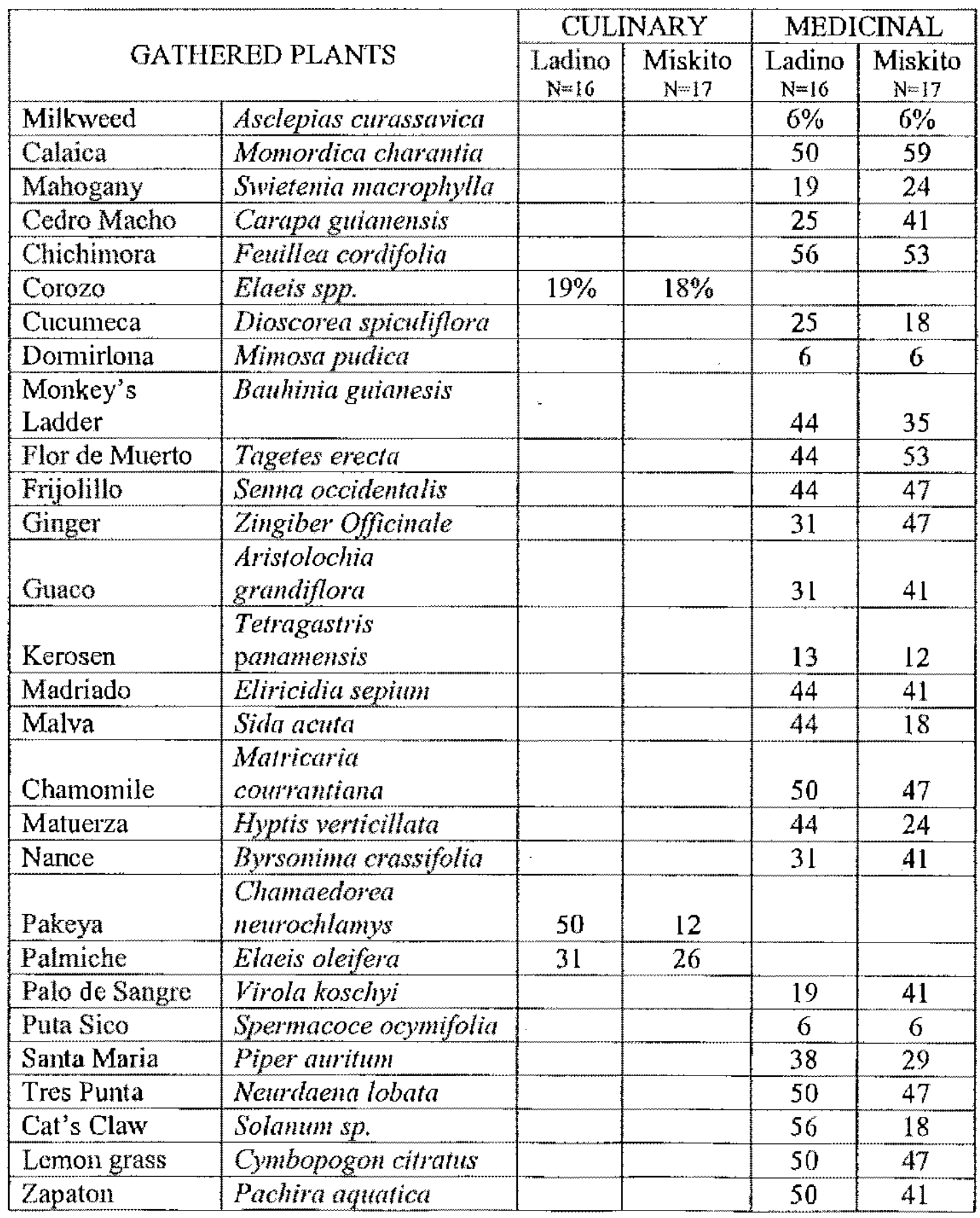


fact that many Ladinos in this area regularly interact with Miskito communities and have been influenced by their practices. Since Banaka, a Miskito community, is the regions' commerce center with two stores and churches, many Ladinos have daily or weekly interactions with Miskitos. In these interactions, information about plants and their uses is shared, especially in the case of medicinal plants. Although pharmaceuticals are preferred, there are many times when they are not available and an alternative is necessary. The ethnic mix of the Ladinos can also influence the lack of difference in plant-use; many tend to be part Miskito and therefore are knowledgeable about Miskito tradition and practices.

One example that did show a significant difference between ethnicities is Solanum spp. (Uña de Gato or cat's claw). Ladinos tend to use the plant more than their Miskito neighbors. Uña de Gato is difficult to identify and has many "look alikes" that are easily confused with the real vine. Medicinal use of this plant requires in-depth knowledge of its appearance and whereabouts. Many look alikes can be easily found growing in guamiles, but the real Uña de Gato is only found in primary forests. Uña de Gato can be found in other regions of Honduras, which may explain why Ladinos are more knowledgeable about this particular plant.

The ethnicity of participants seemed to influence the type of trees that are used (Table 16). Differences between ethnicity were found in the use of Piptadenia spp. (Carbon), Elaeis spp.(Corozo Palm), Swietenia macrophylla (Mahogany), Cordia alliodora (Laurel), Dialium guianense (Paleta), Xylopia sp. (Manga Larga), and Tabebuia rosea (San Juan). The use of Swietenia macrophylla is controversial 
because of its scarcity and economic value. The difference between Ladinos and

Miskitos can be attributed to their willingness to report their use because of the

TABLE 16

Tree Use for House Construction, by Ethnicity

\begin{tabular}{|l|l|c|c|}
\hline \multicolumn{2}{|l|}{} & $\begin{array}{c}\text { Ladino } \\
\mathrm{N}=10\end{array}$ & $\begin{array}{c}\text { Miskito } \\
\mathrm{N}=17\end{array}$ \\
\hline Areno & $31 \%$ & $36 \%$ \\
\hline Bamboo & Guadua sp. & 19 & 12 \\
\hline Carbon & Piptadenia sp. & 6 & 30 \\
\hline Cedro Macho & Carapa guranensis & 13 & 24 \\
\hline Cedro Real & Cedrela fissilis & 6 & 6 \\
\hline Cedro & Tapirira sp. & 19 & 6 \\
\hline Corozo & Elaeis sp. & 0 & 18 \\
\hline Laurel & Cordia alliodora & 88 & 53 \\
\hline Mahogany & Swietenia macrophylla & 11 & 53 \\
\hline Manga Larga & Xylopia sp. & 50 & 18 \\
\hline Nigritu & Bursera simaruba & 6 & 6 \\
\hline Paleta & Dialimim guianense & 25 & 6 \\
\hline San Juan & Tabeburia rosea & 38 & 6 \\
\hline Santa Maria & Calophyllum brasiliense & 63 & 59 \\
\hline Suita & Calptrogyne sarapiquensis & 63 & 53 \\
\hline Yagua & Roystonea dumlapiana & 0 & 18 \\
\hline
\end{tabular}

negative associations with exploiting this valuable species. Other differences can be attributed to proximity to a waterway, the ability to haul wood from distant areas by horse (which can be influenced by income), housing style or housing type (champa versus a pennanent household).

Despite previonsly discussed differences, Cordia alliodora (Laurel), Calophy/hm brasiliense (Santa Maria), and Calptrogyne sarapiquensis (Suita Palm) are the three most commonly used trees between both ethnicities. Cordia alliodora and Calophylltm brasiliense were identified as the second most durable woods after 
Mahogany and can explain their extensive use. Additionally, Calptrogyne sarapiquensis is the most commonly used roofing material throughout the region.

In 1983 Froelich and Schwerin reported that the most valued and durable wood for house construction was yagua palm and that they were cul down whenever encountered. Only two people reported using Roystonea dtmlapiana (Yagua Palm) for the construction of their house, both Miskito; it is possible that these trees are no longer found in abundance around the research area due to exploitation, or that they do not grow well in the research area. One Miskito resident did have small-scale cultivation of yagua specifically for use in house construction. He was building a house for his eldest daughter and intended to use the timber from the palm. Other residents of the research area had begun cultivating a variety of trees including Andira inermis (Areno) and Sivietenia macrophylla (Mahogany). This demonstrates an awareness of diminishing tree resources in local forests and the value of those trees for maintaining traditional house construction.

New developments in concepts such as agroforestry are constantly changing how people in this region use forest resources. For example MOPAWI just recently introduced the Guama project in an attempt to find a multi-use tree species. MOPAWI's program is based on studies that indicate Inga edulis (Guana), a legume and a multi-use tree, can help crop cultivation particularly in areas with highly acidic soils (personal conmunication with Carlos Molinero, MOPAWD). It grows rapidly, rehabilitates soil through nitrogen fixation, can be used as an herb, has strong wood, and produces an edible fruit. The use of this tree was first introduced in Belen and Las 
Marias and during my time in Banaka one gentleman was at the coast receiving training on how this can be used by the people of Banaka and sunounding areas. According to MOPAWI's research, using Inga edulis for agroforestry purposes could potentially iniprove the production of staple crops, increase biodiversity of the area and reduce erosion. If Inga edulis is successful in its agroforestry intentions, it could influence resource use in the research area.

One major influence on resource use in the research area is population size. The population of Gracias a Dios department, $79 \%$ of which are Miskito and many live within the RPBR, quadrupled from 1961 to 1994 . At the same time, the amount of forests changed by agriculture increased 250\% (Dodds 1998b). Dodds (1998b) examines this population growth of the Banaka plains area within the context of four population-environment arguments: Neo-Malthusian, economic processes, structural processes, and a multiple-response theory. He finds that several factors are in place that influence both the rate of population growth and deforestation of lands. Population is growing faster than resource use and so there must be other aspects of their economy that are filling the gap previously supplied by cultivated plants.

Dodds interpretation of the changing relationship between the people of Banaka and their surrounding environment is still relevant today. He identified agricultural intensification, an increase in wage labor, extensification of agricultural lands, and changing political structures and regulations, as factors influencing the uneven rates of population and land-use. Regardless of the uneven rate of growth, both are increasing and will contimue to increase; this will result in the continued loss 
of forests to agriculiural lands unless outside factors are able to stabilize the demand for land inside the reserve. This study demonstrates that several outside influences have and will affect land-use and resource use in the research area. The introduction of ecotourism into the Banaka region could be the next major influence in the changing relationship between peoplc and their environment.

\section{Community Comparisous ou Resource Use}

A comparison of plant and tree use segregated by community revealed very few differences, none of which are significant. The relative proximity of these towns does not support a major ecological or habitat difference, therefore there is little difference in the forest resources available to the three communities. Differences do exist in the spatial distribution of towns, Banaka is centralized around a town center and surrounded by a combination of guamiles and agroforestry areas; Brans and Fuente de Jacob are dispersed. These different spatial arangements and resulting human disturbance have an influence over what plants and trees are in close proxinity to each town. Additionally transportation to each town differs significantly; Fuente de Jacob and part of Brans are inaccessible by water transport while Banaka and the other part of Brans have canoe transportation access. Ease of transportation will influence where and what forest resource communities can access. 


\section{Gender Comparisons on Resource Use}

Gender specific roles in resource use, agriculture, involvement in politics and ecotourism were revealed through formal interviews with both male and female heads of households. Men are more familiar with the agricultural practices of the family and are generally responsible for the planting, collecting, and maintaining agricultural

plots. Men are also more familiar with the size of plots, as well as the names of many trees used for construction and issues related to park management. On the other hand, women are more knowledgeable about plant names and uses, and family demographics. Knowledge about and roles in ecotourism were also gender specific. Women are interested in the comedor and hospedaje aspect with respect to cooking and maintaining the visitor lodge. Men are interested in guiding and transporting guests, construction, trail maintenance, and coordinating transportation from the coast.

\section{Influence From Outside Sources of Income on Resource Use}

A variety of income-generating activities are present in the reserve, but the number of opportunities within each of those activities is limited. In Banaka there are two schoolteachers, two pastors, and two storeowners. Other employment possibilities include construction work, selling meat from hunting or slaughtering livestack, selling extra crops to the coast or other surrounding communities, raising and selling livestock, selling nilk, working for COHDEFOR, or working as a labster diver or canoeman. A few households have fanily members living and working in La Ceiba or other larger towns outside the reserve who send back money. Currently, people of this 
region are fully involved in a cash economy. Not all income-generating activities directly influence forest resource and land use in the region, but the influx of outside income allows residents to purchase goods from outside sources placing less demand on resources of the area.

The lobster industry is the largest income-generating activity and has greatly affected the way of life in the Honduran Mosquitia. It does not directly contribute to deforestation, a major concern with tropical rainforests, but it contributes to a dwindling lobster population in the Caribbean. The first lobster boats entered the reserve to recruit divers in 1963 and by 1992 an estimated 700 males were enployed in the lobster industry, either as divers (buzos) or as canoemen (cayuceros) (Dodds $1998 ; 89)$. The work is extremely dangerous leading to a number of injuries and deaths each year, but the economic gains are significantly higher than any other entployment opportunities in the reserve. Miskitos take advantage of this type of employment more so than other ethnic groups and therefore the community of Banaka is affected more than other towns within the research area. Between the months of July and January when the lobster industry is in operation, many young men from Banaka are gone. The absence of many young men influences agricultural production, forest resource extraction, construction and will be an issue with the emerging ecotourism industry. Additionally, the influx of income for a portion of the year brings opportunities to introduce outside goods, both necessities and amenities. The lobster industry, similar to ecotourisin, generates income allowing residents to be less 
dependent on forest resources. Ecotourism has an advantage over lobstering in that it aims to support forest conservation, rather than exploiting local resources.

\section{Resident Perspectives on Park Management and Regulations}

An original component of this research was to investigate how regulations of the biosphere reserve and awareness of those regulations affect the daily lives and decisions made by residents. During formal interviews it became evident that when questions about the park and its regulations were asked, many interviewees becane uncomfortable. Most participants denied knowing anything about the park, when it was created, or its regulations, I.upario Martines explained that many residents are skeptical of outsiders, particularly when asked about the park, its regulations and their behaviors in compliance with those regulations. There is a widespread fear that in due time COHDEFOR will impose a property tax for residents of the reserve with the expectation that residents will not be able to pay the tax and therefore be forced off the land. Land right issues are sensitive because legally residents have no title or ownership. This apprehension to formally discuss the park with outsiders became even more evident when iny research assistant, Alex Osorno, retnrned from conducting interviews in Fuente de Jacob with detailed answers regarding park issues. The uneasiness felt by participants in response to my questions, persuaded me to stop asking about the topic. The questions were eliminated from the last nine intervievs.

From informal conversations and responses obtained in formal interviews, I determined a general indication of residents' perspectives on the park and its 
regulations (Table 17). Many issues with the park involve COHDEFOR and their perceived lack of interest in people and natural resources of the park. In general there are more negative attitudes about the park, its regulations and COHDEFOR than there are positive (Table 17).

There is also tension between Ladinos and Miskito when it comes to park regulations. The two groups blame each other for poor natural resource practices. One Ladiuo resident blames Miskitos for exploiting mahogany. Conversely, the Miskito generally blame Ladinos for cutting down forests for pastureland, intruding on their lands, and unsustainably extracting natural resources. Overall, there are tensions TABLE 17

Resident Perspectives on Park Management

\begin{tabular}{|l|l|}
\hline Positive & Negative \\
\hline $\begin{array}{l}\text { It protects the environment and } \\
\text { keeps the park beautiful with hills, } \\
\text { rivers, creeks, people and wildlife }\end{array}$ & a It restricts peoples' ability to work \\
and provide for their fanily \\
$\square \quad \begin{array}{l}\text { Regulations are in place to care } \\
\text { for the water source and prevent } \\
\text { destruction of natural resources }\end{array}$ & $\square \quad \begin{array}{l}\text { Residents are ouly allowed to live } \\
\text { as visitors, without rights to the } \\
\text { land; the laws are oppressing }\end{array}$ \\
& $\begin{array}{l}\text { COHDEFOR is not considering } \\
\text { the peoples' need for survival }\end{array}$ \\
& $\square \quad \begin{array}{l}\text { COHDEFOR protects trees, not } \\
\text { people }\end{array}$ \\
& $\begin{array}{l}\text { COHDEFOR is the largest } \\
\text { destructor of natural resources; } \\
\text { they created the plan and do not } \\
\text { follow any of the regulations }\end{array}$ \\
& $\begin{array}{l}\text { It only helps people with money } \\
\text { and does not allow the poor people } \\
\text { to work }\end{array}$ \\
\hline
\end{tabular}


between ethnic groups, as well as between each of those ethmic groups and

COHDEFOR. The issues surrounding park regulations, and resource and land rights, are at the root of most tensions.

\section{Concluding Remarks}

The Honduran Mosquitia has seen a number of boom and bust economies in the region including rubber tapping, banana cultivation, and mahogany logging; lobster diving is the latest trend and it may be reaching its limits. Currently, ecotourism is being encouraged by AFE/COHDEFOR, MOPAWI, the reserve's funding agencies and many involved international agencies. The altenative income generated by ecotourisin has the potential to decrease dependency on an extractive economy and on boom and bust cycles, including lobstering, of the global economy, as well as enuphasize the conservation and protection of the regions biological and cultural resources.

Ecotourism was introduced into the Río Plátano Biosphere Reserve in the late 1980 s and research has been conducted in communities to determine the effeets of ecotourism on biodiversity, economy and socio-cultural developments. This research has resulted in lessons for establishing ecotourism and analysis conducted on changes in communities from the development of ecotourism (Anderson N.d.; Nielson \& Munguia 1998; Nielson et al, 2003). One conflict in the town of Las Marias prior to establishing a community-based ecotourism system was the lack of regulations on fishing and hunting for visitors. This caused environmental impacts because locals 
felt pressure to provide wild game and fish for visitors, depleting supplies for local residents. This conflict, along with conflicts revolving around income distribution, were both resolved in Las Marias with the development of norms and regulations published by a locally established Ecotourism Committec. The involvement of the community in establishing committees and regulations for the ecotourism industry ensures that community members have some ownership in the industry.

Nielson et al. (2003) provides some general conclusions generated from ecotourism research in the reserve. Thcy found that strategies employed in three communities have produced important economic benefits; however, along with increased income, comnunity menbers have access to more efficient technologies, such as chainsaws and rifles, which can cause more pressures on the resource base. Some positive results include an increase in the conservation value of the reserve and local pride in conserving resources, stemming from the interaction with ecologically oriented visitors. Additionally, local organizations for managing ecotourism issues are increasing, thus minimizing negative impacts on local culture.

Ecotourism has the potential to transform the Honduran Mosquitia into an area still dependent on forest resources for cash earning opportunities, but where residents are dependent on protecting resources, not exploiting them. Based on the data I collected and observations made throughout my stay in the research area, I found a number of issues that will influence the establishment and maintenance of an ecotourism industry in Banaka. 
One limitation to the success of ecotourism in Banaka is a lack of commitment by community members to this industry. Currently, the amount of time people are willing or able to dedicate to ecotourism is dependent on seasons; when preparing, planting and harvesting agricultural crops the ability to participate in an alternative activity is reduced. Community members will still have to depend on agriculture because initially the amount of cash earned through ecotourism will probably not be sufficient to buy food throughout the year, making it necessary to plant crops to ensure their food supply year round. Community members" ability to commit to ecotourism year round, or not, will directly affect the number of visitors the town can accommodate. The cominunity of Las Marias deals with this issue by using a rotation system for all guides where names are picked in order down a list. If the member is not available or in town and has not designated another person to fill their place, they forfeit their turn (see Appendix E).

Another factor influencing the ability of conmunity members to commit to ecotourism year round is the lobster industry. Currently, young men from Banaka work as lobster divers when the lobster season is open (July-Jannary). The cash earning potential in the lobster industry exceeds the potential for cocoturism, especially during the first few years when community members will have to establish a system for attracting visitors. A lobsterman can earn anywhere up to $\$ 10,000$ Lempiras during a diving trip lasting up to two weeks. The cost for one visitor staying in Banaka for two weeks, including guides, meals and lodging is about $\$ 2,590$ 
Lempiras, and that would cover, at a minimum, four community members' earnings over that time period.

One more concern is the ability to transport goods and passengers in and out of Banaka. Streamflow in Banaka Creek is inconsistent; it dries up during the dry seasons and floods during the rainy seasons. Both situations make the creek difficult to travel. Additionally, when there is stormy weather the Ibans Lagoon becones difficult to cross, cutting off transportation between the coastal communities and the interior Banaka area. The difficulty of traveling along Banaka Creek is not only a problem in transporting potential visitors and their gear, but it is also a problem in transporting provisions for those visitors and community members. If there is a decrease in the dependency on forest resources for food, timber, and medicine then there must be an increase in the amount of goods received from outside sources. Thus, Banaka becomes more dependent on the ability to transport goods from coastal towns. Both the increase in receiving outside goods and transportation accessibility will benefit the communities of this region since currently, there is often a lack of goods in the region. An increase in transportation and accessibility for tourists however, can also produce related negative results. Most inportant is the increased pressure on forest resources: using trees from local forests to build and maintain hospedajes, comedors and canoes; increased clearing for agriculture to provide surplus food for guests; and an increase in pasture land for livestock.

Ecotourism development, forest resource access and land-use in the research area are influenced by multiple factors: (1) its location within a biosphere reserve, (2) 
evolving models of protected areas and conservation, (3) alternate models of natural resource management, and (4) changes in land-use and cover. These factors all involve multiple levels of political interests, which shape forest resource access and land-use in the RPBR, as a protected area. UNESCO's promotion of the biosphere reserve model to balance biodiversity with sustainable use of land, and the RPBR's promotion of ecotourism to contribute to sustainable economic development and minimize negative impacts to natural ecosystems, exemplifies a link between international and regional influences on a local area. Follow-up research in the study region should address questions such as: does ecotourism effectively conserve both biodiversity and culture as proposed through the biosphere reserve model? And does ecotourism resolve the conflict between conservation efforts and the economic needs of local populations?

Dodds' (1998b) research conducted from 1960 to 1995 on population growth and forest cover change in the Banaka agricultural region revealed a $250 \%$ increase in areas disturbed from agriculture, from $282 \mathrm{ha}$ to $707 \mathrm{ha}$, with a population increase of over $400 \%$, resulting in an increase from 2 to 3.5 persons/hectare. This data on population and agricultural land use in the region and the emerging ecotourism industry provides opportunities for future research to investigate whether ecotourisn provides a mechanism for conservation of forest resources and land while maintaining local livelihoods.

As long as there is conflict between conservation efforts and economic needs of local populations, new ideas and nethods for resolving that conflict will evolve. 
Examinations of whether or not ecotourism serves as an effective tool for resolving the on-going conflict is necessary. Evidence from this research suggests that a community within the RPBR establishing ecotourism requires community accepted visitor regulations, year round community involvement and participation, and reliable transportation routes. Progress on the sustainability of the ecotourism industry, not only in Banaka, but also in the entire Río Plátano Biosphere Reserve must be monitored in order to ensure the protection of the areas considerable biodiversity and cultural diversity. This work provides baseline information for future research on the influences of ecotourism on forest resource use and land-use. 


\section{REFERENCES CITED}

AFE-COHDEFOR, KFW, GTZ, GFA-AGRAR, and BRP. 2003. Normas para el Manejo y Proteccion de los Recussos Natural y Culturales. Tegucigalpa, Honduras.

2000. Plan de Manejo: Reserva del Hombre y La Biosfera del Rio Plátano. Tegucigalpa, Honduras.

AFE-COHDEFOR, BRP, MOPAWI, The Nature Conservancy, and USAID, 2002. Reserva del Hombre y la Biosfera del Rio Plátano: Diagnostics Ambiental. Tegucigalpa, Honduras.

Anderson, Arden. No Date, Preliminary Guidelines for Ecotourism Management in the Rio Platano Biosphere Reserve, Honduras. Document found in the MOPAWI library in Tegucigalpa.

Belsky, Jill M. 2003. Unmasking the "Local" Gender, Community, and the Politics of Community-Based Rural Ecotourism in Belize. In Contested Nature: Promoting International Biodiversity with Social Justice in the Twenty-first Centuy, eds. Steven R. Brechin, Peter R. Wilshusen, Crystal L. Fortwangler and Patrick C. West, 89-101. Albany, NY: State University of New York Press, Albany.

Blaikie, Piers and Harold Brookfield, 1987. Land Degradation and Society. London and NY: Methuen \& Co. Ltd

Bonta, Mark. 2003. Seven Names for the Bellbirl: Conservation Geography in Honduras. College Station: Texas A\&M University Press.

Boo, Elizabeth. 1992. La Explosion del Ecoturismo: Planificacion para el Manejo y Desarollo. PANSH Seria de Documentos Tecnicos, No. 2. Washington D.C.: WWF。

Boxer-Macomber, Lauri and Ethan Macomber. 1997. Informe Amual del 
Ecotourismo: Las Marias, Gracias a Dios, La Reserva de La Biosfera Rio Plátano, Honduras, CA. MOPAWI, Cuerpo de Paz, USDI, USAID, IHAH, IHT, WWF.

Brandon, K., K.H. Redford, and S.E. Sanderson, editors. 1998. Parks in Peril: People, Politics, and Protected Areas. Washington D.C.: Island Press.

Brothers, T.S. 1997. Deforestation in the Dominican Republic: A Village-level View. Envirommental Conservation 24(3): 213-223.

Campos-Dudley, Liliana. 1992. Beni: Surviving the Crosswinds of Conservation. Américas 44(3): 6-14.

Carew-Reid, Jeremy. 1990. Conservation and Protected Areas on South-Pacific Islands: The Importance of Tradition. Environmental Conservation 17(1): 29. 38 .

Cater, Erlet. 1994. Introduction. In Ecotourism: A Sustainable Option?, eds. E. Cater and G. Lowman, 3-17. West Sussex, England: John Wiley \& Sons Ltd.

Ceballos-Lascurain, Hector. 1993. Ecotourism as a Worldwide Phenomenon. In Ecotourism: A Guide for Plamners and Managers, eds. K. Lindberg and D. Hawkins, 82-116. North Bennington, VT: The Ecotourism Society.

Chapin, Mac. 2004. A Challenge to Conservationists. World-Watch November/December: 17-31.

Denevan, William and Christine Padoch. 1988. Chapter 8: Conclusions and Recommendations. In Swidden-Fallow Agroforestry in the Peruvian Amazon, eds. Williain M. Denevan and Christine Padoch, 97-102. Bronx, NY: The New York Botanical Garden.

DeWalt, Billie R. 1999. Combining Indigenous and Scientific Knowledge to Improve Agriculure and Natural Resource Management in Latin America. In Traditional and Modern Natural Resource Management in Latin America, eds. Francisco J. Pichón, Jorge E. Uquillas, and John Frechione, 101-121. Pittsburgh, PA: University of Pittsburgh Press.

Diamantis, Dimitrios. 1999. The Concept of Ecotourism: Evolution and Trends. Current Issues in Tourism 2(2\&3): 93-122.

Dodds, David. 1998. Lobster in the Rain Forest: The Political Ecology of Miskito Wage Labor and Agricultural Deforestation. Journal of Political Ecology 5:83-108. 
1998b. Population Growth and Forest Cover Change in the Rio Plátano Biosphere Reserve, Honduras. Center for the Study of Institutions, Population and Environmental Change. www.cipec.org/research/demography/dodds_ppr.html (Accessed on 12/8/04).

1994. The Ecological and Social Sustainability of Miskito Subsistence in the Rio Plátano Biosphere Reserve, Honduras. The Cultural Ecology of Swidden Horticulturalists in a Protected Area. Ph.D. dissertation, University of California, Los Angeles.

1987. Miskito Lands and Culture Change in Eastern Honduras: An Analysis with Recommendations for Development Planning. Master's Thesis, University of California, Los Angeles.

Farrell, Tracy A. and Jeffrey L. Marion, 2001. Identifying and Assessing Ecotourism Visitor Impacts at Eight Protccted Areas in Costa Rica and Belize. Envirommental Conservation 28(3): 215-225.

Foehlich, Jeffery W. and Karl H. Schwerin. 1983. Conservation and Indigenous Human Land Use In the Rio Plátano Watershed, Northeast Honduras. Research Paper Series No. 12. Department of Anthropology, University of New Mexico.

Fortwangler, Crystal L. 2003. Incorporating Social Justice and Human Rights into Protected Areas Policies. In Contested Nature: Promoting International Biodiversity with Social Justice in the Twenty-first Century, ed. Steven R. Brechin, Peter R. Wilshusen, Crystal L. Fortwangler and Patrick C. West, 103115. Albany, NY: Statc University of New York Press, Albany.

Fraser, Elizabeth. 2003. Conservation Versus Survival: A Cultural Ecological Study of Changing Settlement Patterns, Cultures, and Land-Use in the Rio Plátano Biosphere Reserve of Northeastern Honduras. Ph.D. Dissertation, Louisiana State University, Agricultural and Mechanical College.

Glick, Dennis and Jorge Betancourt. 1983. The Rio Platano Biosphere Reserve: Unique Resource, Unique Alternative (Honduras). Ambio 12(3/4): 168-173.

Goulding, M. N.J.H Snith and D.N. Mahar. 1996. Floods of Fortune: Ecology and Economy Along the Amazon. New York: Columbia University Press.

Helms, Mary. 1972. Asang, Adaptations to Culture Contact in a Miskito Community. Gainsville, FL: University of Florida Press. 
Herlihy, Peter. 1999. Indigenous and Ladino Peoples of the Rio Plátano Biosphere Reserve, Honduras. In Endangered Peoples of Latin America: Struggles to Survive and Thrive, ed. Susan C. Stonich. Westport, CT: Greenwood Press.

1997. Indigenous Peoples and Biosphere Reserve Conservation in the Mosquitia Rain Forest Corridor, Honduras. In Consenvation throngh Cultural Survival: Indigenous Peoples and Protected Areas, ed. Stan Stevens, 99-129. Washington DC: Island Press.

1993. Securing a Homeland: The Tawahka Sumu of Mosquitia's Rain Forest. In State of the Peoples: A Global Human Rights Report on Societies in Danger, ed. Marc S. Miller, 54-62, Boston; Beacon Press.

1990. "Wildlands" Conservation in Central America during the 1980's: A Geographical Perspective. Yearbook, Conference of Latin Americanist Geographers 17/18: 31-43.

Herlihy, Peter and A.P. Leake, 1997. Participatory Research Mapping of Indigenous Lands in the Honduran Mosquitia. In Demographic Diversity and Change in the Central American Isthmus, ed. A.R. Pebley and L. Rosero-Bixby, 707-736. Santa Monica, CA: Rand Books.

Herrera-MacBryde, Olga, 1994. North-East Honduras and Rio Plátano Biosphere Reserve. Middle America Report; CPD Site MA15. Department of Botany, Smithsonianl Institute.

Honey, M. 1999. Ecotontism and Sustainable Development: Who Owns Paradise? Washington DC: Island Press.

House, Paul and Indalesio Sanchez. 1997. Mayangna Panan Basmi (Nuestras Plantas Medicinales): Plantas Medicinales del Pueblo Tawahka. London: Department of Botany, The Natural History Museum.

Houseal, B., C. MacFarland, G. Archibold, and A. Chiari. 1985. Indigenous Cultures and Protected Areas in Central America. Cultural Sumvival Quarterly $9(1): 10-20$.

King, David A and William P. Stewart, 1996. Ecotourism and Commodification: Protecting People and Places. Biothversity and Conservation 5: 293-305.

Klepeis, P. 2000. Deforesting the Once Dcforested: Land Transformation in Southeastern Mexico. Ph.D. Dissertation. Clark University.

Klepeis, P. and B.L. Turner II. 2001. Integrated Land History and Global Change 
Science: The Example of the Southern Yucatan Pennisular Region Project. Land Use Policy 18: 27-39.

Knapp, Gregory and Peter Herlihy, 2002. Mapping the Landscape of Identity. In Latin America in the $21^{\text {si }}$ Century: Challenges and Solutions, ed. Gregory Knapp, 251-268. Austin; The University of Texas Press, Conference of the Latin Americanist Geographers.

Lagos-Witte, Sonia and Janeth Guardado. 2001. "Mamual Popular de Plantas Medicinales Commes de la Cosfa Allantica de Honduras. Honduras: TRAMIL.

Lindberg, Kreg 1993, Economic Issues In Ecotourism Management, In Ecotomism: A Guide for Plamers and Managers, eds. K. Lindberg and D. Hawkins, 82116. North Bennington, VT: The Ecotourism Society.

Macomber, Ethan, Lauri Boxer-Macomber, and Arden Anderson. No Date. Visitor's Guide to the Rio Plitano Biosphere Reserve. Comision Centroantericana de Ambiente y Desarrollo, Peace Corps, PROARCA/CAPAS, MOPAWI, and USAID.

Matson, P.A., R. Naylor and I, Ortiz-Manastario. 1998. Integration of Environmental, Agronomic and Economic Aspects of Fertilization Management, Science 280: $112-115$.

McNeely, Jeffrey A. 1982. Introduction: Protected Areas are Adapting to New Realities, In National Parks, Conservation, and Development: The Role of Protected Areas in Ststaining Society, eds. McNeely, Jeffrey A. and Kenton R., 1-7. Proceeding of the World Congress on National Parks, Bali, Indonesia. Washington D.C.: Stnithsonian Institution Press.

Naughton-Treves, Lisa, 2002. Wild Animals in the Garden; Conserving Wildlife in Amazonian Agroecosystems. Annals of Association of American Geographers 92(3): 488-506.

Nelson-Sutherland, Dr. Cyril Hardy, 1986. Plantas Comtmes de Honduras. Honduras: Editorial Universitaria.

Nielson, Eric. 1995. Community Participation in Wildlands Management: A Case Study of Indigenous Efforts to Plan and Manage Sustainable Ecotourism in the Rio Plátano Biosphere Rescrve, Honduras. Master's of Arts in Public Policy, Intermational Development, Rutgers University.

Nielsen, Erik and Osvaldo Munguia, 1998. Community Participation in Wildlands 
Management: A Case of Indigenous Efforts to Plan and Manage Sustainable Ecotourism in the Rio Plátano Biosphere Reserve, Honduras. The World Bank/WBI's CBNRM Initiative Case Study.

Nielsen, Erik, Angela Mat1in, Andy Drumm, Osvaldo E. Muguia, Adalberto Padilla L., and Andrew G. Soles. 2003. Towards Conserving Culture and Biodiversity: Community-based Ecorourism in the Rio Plátano Biosphere Reserve, Honduras. Draft (unpublished) photocopy.

Nietschmant, Bernard Q. 1997. Protecting Indigenous Coral Reefs and Sea Territories, Miskito Coast, RAAN, Nicaragua. In Conservation through Cultural Survival: Indigenous Peoples and Protected Areas, ed. Stan Stevens, 193-224. Washington DC: Island Press.

1992. The Interdependence of Biological and Cultural Diversity. Occasional Paper Number 21. Kenmore, WA: Center for World Indigenous Studies.

1973. Between Land and Water: The Subsistence Ecology of the Miskiro Indians, Eastem Nicaragua, New York: Seminar Press.

Place, S.E., ed. 1993. Tropical Rainforests: Latin American Nature and Sociery in Transition. Wilmington: Scholarly Resources.

Ross, SheryI and Geoffrey Wall. 1999. Ecotourisn: Towards Congruence Between Theory and Practice. Tourism Management 20: 123-132.

Schwartzman, Stephen, Adriana Moreira, and Daniel Nepstad, 2000. Rethinking Tropical Forest Conservation: Perils in Parks. Consevanion Biology 14(5): 1351-I357.

Serrão, E.A., D. Nepstad , and R. Walker. 1996. Upland Agricultural and Forestry Development in the Amazon: Sustainability, Criticality and Resilience. Ecological Economics 18(1): 3-I3.

SIetto, Bjorn. 1999. New Patterns on Shifting Shores. Americas 51(3): 28-37

Smith, N.J.H., J.C. Falesi, P. Alvim, and E.A.S. Serrão. 1996. Agroforestry Trajectories Among Smallholders in the Brazilian Amazonia. Global Envirommental Change-Human and Policy Dimensions 1(4): 313-320.

Southgate, D. 1990. The Causes of Land Degradation Along "Spontaneously" Expanding Agricultural Frontiers in the Third World. Land Economics 66: 93-101. 
Stem, Caroline J., James P. Lassoie, David R. Lee, David D. Deshler, John W. Schellas, 2003. Community Participation in Ecotourism Benefits: The Link to Conservation Practices and Perspectives. Society and Natural Resources 16: $387-413$.

Stevens, Stan. 1997. The Legacy of Yellowstone. In Conservation flrough Cultural Survival: Indigenous Peoples and Protected Areas, ed, Stan Stevens, 13-32. Washington DC: Island Press.

Sundberg, Juanita 1998. Strategies for Authenticity, Space, and Place in the Maya Biosphere Reserve, Peten, Guatemala, Yearbook, Conference of Latin Americanist Geographers 24: 85-96,

Talbot, Lee M. 1982. The Role of Protected Areas in the Implementation of the World Conservation Strategy. In National Parks, Conservation, and Development: The Role of Protected Areas in Sustaining Society, eds. McNeely, Jeffrey A. and Kenton R. Miller, 15-16. Proceeding of the World Congress on National Parks, Bali, Indonesia. Washington D.C.: Smithsonian Institution Press.

UNESCO. Frequently Asked Questions on Biosphere Reserves. http://wwww.unesco.org/mab/nutshell.htm (Accessed on 6/11/2003).

Vadjunee, Jacqueline, Laura Schneider, and B.L.Turner II. 2003. Land-Change Science: The Contributions of Latin Americanist Geographers to Global Environnental Change and Sustainability Research. In Latin America in the $21^{\text {st }}$ Century: Challenges and Solutions, ed.Gregory Knapp, 171-205. Austin: The University of Texas Press, Conference of the Latin Americanist Geographers.

Voeks, Robert, 2004. Disturbance Pharmacopicas: Medicine and Myth from the Humid Tropics. Amals of the Association of American Geographers 94(4): 868-888.

Wall, Geoffrey, 1997. Forum: Is Ecotourism Sustainable? Environmental Management 21(4): 483-491.

West, Patrick C., Crystal L. Fortwangler, Valentin Agbo, Miclaale Simsik, and Nestor Sokpon. 2003. The Political Economy of Ecotourism: Pendjari National Park and Ecotourism Concentration in Northern Benin, In Contested Nature: Promoting International Biodiversity with Social Justice in the Twenty-first Century, ed. Steven R. Brechin, Peter R. Wilshusen, Crystal L. Fortwangler 
and Patrick C. West, 103-115. Albany, NY: State University of New York Press, Albany.

Wilshusen, Peter R., Steven R. Brechin, Crystal L. Fortwangler, and Patrick C. West, eds. 2003. Contested Nature: Conservation and Development at the Turn of the Twenty-First Century. In Contested Natwe: Promoting International Biodiversity with Social Justice in the Tiventy-First Century, ed. Steven R. Brechin, Peter R. Wilshusen, Crystal L. Fortwangler and Patrick C. West, 1 22. Albany, NY: State University of New York Press, Albany.

Young, Emily H. 1999. Balancing Conservation with Development in Small-Scale Fisheries: Is Ecotourism an Empty Promise. Human Ecology 27(4): 581-620.

Zimmerer, Karl S, 2000. The Reworking of Conservation Geographies:

Nonequilibrium Landscapes and Nature-Society Hybrids. Amals of the Associalion of American Geographers 90(2): 356-69.

Zimmerer, Karl S., and Eric D. Carter. 2002. Conservation and Sustainability in Latin America and the Caribbean. In Latin America in the $21^{\text {st }}$ Century: Challenges and Solutions, ed. Gregory Knapp, 207-249. Austin: The University of Texas Press, Conference of the Latin Americanist Geographers.

Zimmerer, Karl S, and Kenneth Young, ed. 1998. Nature's Geography, New Lessons for Conservation in Developing Countries. Madison, WI: The University of Wisconsin Press.

Zimmerer, Karl S, and Thomas J. Bassett, ed. 2003. Political Ecology: An Integrative Approach to Geography and Environment-Development Studies. New York and London: The Guilford Press. 


\section{APPENDIX A \\ FORMAL INTERVIEW QUESTIONNAIRE}

ID Number: $\_$Date: $\ldots$ Location:
Sex: $\mathrm{M} / \mathrm{F} \quad$ Age: $\quad$ Married: $\mathrm{Y} / \mathrm{N}$

1. Que ethnicity es? Y su esposo/a?

2. Donde nacio? Y su esposo/a?

3. Tienen hijos? Cuantos y cuantos años tienen?

4. Tienen otra casa? Donde? Cuanto tiempo pasa allà cada an̆o? Porque tienen otra casa, Que haces allà?

5. Hace cuanto tiempo que vives aqui? Donde vivio antes? Por que salio de alli? Por que vino aqui?

6. Tienen solare o lote de agricultura? 
Que sembras? Que cultivos y que arboles de fruta?

\begin{tabular}{|l|l|l|l|l|l|l|l|}
\hline & & & & & & \\
\hline & & & & & & & \\
\hline
\end{tabular}

Cuanto tierra tiene para cada cultivos (o todos)?

Cuantos arboles tiene de cada fruta?

Que es la distancia de su casa a su agricultura?

Cuantos años trabaja un parte de tierra y para cuantos años tiene en guamile?

7. Usas unos cultivos para el negocios o cambio con otros? Que cambias? Con quien?

8. Que tipo de arboles usé para la construccion de su casa? De donde consegueslos (bosque, compras, sembras)?

9. Usas plantas del bosque para la alinentacion o medicinales, como tè, herbias, especias, enfermadades? Que usas? Para que? Recoges o consegues en otro manera? Es abundante?

* The first 16 interviews were asked these questions to devise a list of plants. The rest of the interviews used conducted using a checklist of plants and asking if there were any more they could add to the list. Checklists are included at the end of the interview. 
10. Tiene ganados o otro animals? Que tipos tiene? Estan aqui en Banaka?

11. Que sabe del parque, La Reserva de la Biosfera del Rio Plátano?

12. Recuerdas cuando la Reserva establecido un plan de manejo? Recuerdas la zonificacion del parque? Hay personas del gobierno que viene aqui para hablar con Uds. sobre las usas de la tierra o los reglamentos del parque?

13. Sabe que el pueblo de Banaka esta empezando una industria de ecoturismo? Que piensas del industria para el pueblo? Creas que ecoturismo va a taer oportunidades aqui?

14. Tienes interes in participando en el ecoturismo? Que quieres hacer? Tiene capacitation para la industria? 


\begin{tabular}{|c|c|}
\hline $\begin{array}{l}\text { CULINARY } \\
\text { PLANTS }\end{array}$ & MEDICINAL PLANTS \\
\hline Ajo & Achoite \\
\hline Albahaca & Albahaca \\
\hline Achoite & Alkabon Saika (Miskitu) \\
\hline Culantro & Aromero \\
\hline Coco & Calaica \\
\hline Chili & Chichimora \\
\hline Cebollo & Canela \\
\hline Corozo & Coco \\
\hline Palmiche & Zapaton \\
\hline Pakeya & Cedro Macho \\
\hline Pimenta & Escalara de Mono \\
\hline Nance & Ensenzilla Coronada \\
\hline Name & Guaco \\
\hline Zapote & Guayaba \\
\hline Patastiyo & Nance \\
\hline Ayote & Ciruela \\
\hline \multirow[t]{27}{*}{ Cacao } & Aguacate \\
\hline & Maranon \\
\hline & Gengibre \\
\hline & Limon \\
\hline & Manzanilla \\
\hline & Matuerza / Arspata \\
\hline & Palo de Sangre \\
\hline & Santa Maria \\
\hline & Tres Punta \\
\hline & Una de Gato \\
\hline & Guanabana \\
\hline & Yucca \\
\hline & Zacate \\
\hline & Ajo \\
\hline & Culantro \\
\hline & Caoba \\
\hline & Flor de Muerto \\
\hline & Frijolillo \\
\hline & Madriado \\
\hline & Mango \\
\hline & Cucumeca \\
\hline & Malva \\
\hline & Ciraisa (Miskitu) \\
\hline & Algodon \\
\hline & Dormilona (Miskitu) \\
\hline & Puta Sica (Miskitu) \\
\hline & Kerosen \\
\hline
\end{tabular}




\section{APPENDIX B}

\section{ECOTOURISM COMMITTEE NOTES}

\section{6-23-04: MOPAWI meeting in Banaka regarding Ecotourism}

4 people present: Lupario Martines, Kerry Julian Mejia, Emilio Zelaya Apinton, and Celso Zelaya Apinton

- Location of hospedaje: the planned location is separated from the rest of town making communication between visitors and town inembers difficult. There will be no interaction with the comnunity and there is a lot of mud along the trail getting to the site. Will there be any security issues with peoples belongings because of the site's isolation?

- Prohibit animals to walking on the trail -... create an altemative route

- Isolation - who will talk to and provide assistance to visitors at night? No-one lives close enough to have a person around at all times in case the visitors need something

- Store - it is a long walk from the planmed site

o How is the whole town planning on working together?

- Form a comnittee for the entire town of Banaka

- Could have inultiple lodges, but the committee needs to have representatives from all sides of the community to work out the details

․ When is the town going to organize? Can we set a specific date? Right now the teacher is not in town and he needs to be included. First step is to form a committee, then finish the lodge, then come up with a list of norms and standards to accommodating visitors, visitor expectations, costs, etc.

Celso mentions that he would like to turn his louse into a lodge and is planning on building another 2 room house next to his house as a second lodge. Carlos and Leonardo (from MOPAWn) are excitcd to hear about this this means if visitors are directed here now, there is someplace to stay.

- Lupario and Carlos (MOPAWI) did the majority of the talking throughout the meeting. In the end, no dates were set nor were definite plans. 


\section{APPENDIX C}

\section{PLANT AND TREE LIST: SPANISH, ENGLISH, AND SCIENTIFIC NAMES}

\begin{tabular}{|c|c|c|}
\hline SPANISH NAME & $\begin{array}{l}\text { ENGLISH } \\
\text { NAME }\end{array}$ & SCIENTIFIC NAME ${ }^{1}$ \\
\hline \multicolumn{3}{|c|}{ PLANTS } \\
\hline Achoite & Anuatto & Bixa orellama \\
\hline Aguacate & Avocado & Persea mubigena \\
\hline Albahaca & Basil & Ocimam campechiamum \\
\hline Algodon & Cotton & Eossypinm barbadense \\
\hline $\begin{array}{l}\text { Alkabon Saika } \\
\text { (Miskito) }\end{array}$ & Milkweed & Asclepias curassavica \\
\hline \multicolumn{3}{|l|}{ Aromero } \\
\hline Cacao & Coco & Theobroma cacao \\
\hline Calaica & & Momordica charantia \\
\hline Caoba & Mahogany & Swietenia macrophylla \\
\hline Cedro Macho & & Carapa guianensis \\
\hline Chichimora & & Feuillea cordifolia \\
\hline Chile & Chile, red & Capsicumt ammunt \\
\hline Ciraisa (Miskitu) & & Capraria biflora \\
\hline Coco & Coconut & Cocos mucifera \\
\hline Corozo & & Elaeis spp. \\
\hline Cuculmeca & & Dioscorea spiculiflora \\
\hline Culantro & Cilantro & Eryngium carlinae \\
\hline Dormirlona & & Mimosa pudica \\
\hline \multicolumn{3}{|l|}{ Ensenzilla Coronada } \\
\hline Escalara de Mono & Monkey's Ladder & Banhimia guianesis \\
\hline Flor de Muerto & & Tagetes erecta \\
\hline Frijolillo & & (Cassia) Senma \\
\hline
\end{tabular}

\footnotetext{
'Scientific names were obtained by Dr. Nelson, Professor at the Universidad Nacional Autonoma de Honduras who identified plant samples from the research area, Additionally I used Foehlich and Schwerin 1983; House and Sanchez 1997; AFE-COHDEFOR, BRP, MOPAWl, The Nature Conservancy, and USAID 2002; Frser, Elizabeth 2003; Macomber, Ethan, Lauri Boxer-Macomber, and Arden Anderson; and TRAMIL Programa, Centroamerica/ ENDA CARIBE 2001.
} 


\begin{tabular}{|c|c|c|}
\hline & & accidentalis \\
\hline Guaco & & Aristolochia grandiflona \\
\hline Guanabana & Soursop & Annona muricata \\
\hline Guayaba & Guava & Psidiam guyava \\
\hline Jengibre & & Zingiber officinale \\
\hline Kerosen & & Tetragastris panamensis \\
\hline Limon & Lemon & Cirrus aurantifolia \\
\hline Madriado & & Eliricidia sepitm \\
\hline Malva & & Sida acuta \\
\hline Mango & Mango & Mangifera indica \\
\hline Manzanilla & Chamomile & Matricaria contrantiana \\
\hline Maranon & Cashew & Anacardim occidentale \\
\hline Matuerza & & Hyptis verticillata \\
\hline Nance & Nance & Byrsonima crassifolia \\
\hline Pacaya & & $\begin{array}{l}\text { Chamaedorea } \\
\text { neurochlamys }\end{array}$ \\
\hline Palmiche & & Elaeis oleifera \\
\hline Palo de Sangre & & Virola koschyi \\
\hline Puta Sica (Miskitu) & & Spermacoce ocymifolia \\
\hline Santa Maria & & Piper atoritum \\
\hline Ciruela & & Prinus spp. \\
\hline Tres Punta & & Neudaena lobata \\
\hline Una de Gato & Cat's Claw & Solanum sp. \\
\hline Name & Yam & Dioscorea, spp. \\
\hline Yucea & Manioc & Manihot esculenta \\
\hline Zacate de limon & Lemon grass & Cymbopogon citratus \\
\hline Zapaton & & Pachira aquatica \\
\hline Zapote & Mamey & Pouferia mammosa \\
\hline \multicolumn{3}{|c|}{ TREES } \\
\hline Areno & & Andira inermis \\
\hline Caoba & Mahogany & Swietenia macrophylla \\
\hline Carbon & & Piptadenia $s p$ \\
\hline Cedro & & Tapirirasp. \\
\hline \multicolumn{3}{|l|}{ Cedro Espina } \\
\hline Cedro Macho & & Carapa guianensis \\
\hline Cedro Real & & Cedrela fissilis \\
\hline Corozo & & Elaeis spp. \\
\hline Guama & & Inga sp. \\
\hline Laurel & Laurel & Cordia alliodora \\
\hline Manga Larga & & Xylopia sp. \\
\hline Nigritu & & Bursera simaruba \\
\hline
\end{tabular}




\begin{tabular}{|l|l|l|}
\hline Paleta & & Dialium gutianense \\
\hline Pino & Caribbean Pine & Pinus caribaea \\
\hline San Juan & San Juan & Tabebura rosea \\
\hline Santa Maria & Santa Maria & Calophyllum brasiliense \\
\hline Suita & Suita Palm & Calptrogyne sarapiquensis \\
\hline Tarra & Bamboo & Guadua sp. \\
\hline Varillo & & Symphonia globulifera \\
\hline Yagua & Yagua Palm & Roystonea dunlapiana \\
\hline
\end{tabular}




\section{APPENDIX D}

\section{AGRICULTURAL CROP LIST: SPANISH, ENGLISH, AND}

\section{SCIENTIFIC NAMES}

\begin{tabular}{|c|c|c|}
\hline SPANISH NAME & $\begin{array}{l}\text { ENGLISH } \\
\text { NAMES }\end{array}$ & SCIENTIFIC NAMES ${ }^{1}$ \\
\hline Achoite & Annatto & Bixa orellana \\
\hline Aguacate & Avocado & Persea nubigena \\
\hline Arroz & Rice & Oryza sativa \\
\hline Ayote & Pumpkin & Curcubila pepo \\
\hline Cacao & Cacao & Theobroma cacao \\
\hline Cafe & Coffee & Coffea spp. \\
\hline Camote & Sweet potato & Ipomoea batatas \\
\hline Cana & Sugar cane & Saccharum officinartum \\
\hline Chili Dulce & Sweet Peppers & Capsictm spp. \\
\hline Chili Caliente & Chili Peppers & Capsicum spp. \\
\hline $\mathrm{Coco}$ & Coconut & Cocos nucifera \\
\hline Frijol & Beans & Phaseolus vilgaris \\
\hline Guanabana & Soursop & Amona Americana \\
\hline Guineo & Bananas & Musa spp \\
\hline Guyaba & Guyava & Pisidium guayava \\
\hline Limon & Lemon & Citrus aurantifolia \\
\hline Maiz & Maize & Zea mays \\
\hline Malanga & Cocoyam & Xanthosoma sagittifolimm \\
\hline Malanga & Taro, dasheen & Colocasia esculenta \\
\hline Mango & Mango & Mangifera Indica \\
\hline Manzana & Rose apple & Eugenta jambos \\
\hline Maranon & Cashew & Anacarditm occidentale \\
\hline Mazapan & Breadfruit & Artocarpus altilis \\
\hline
\end{tabular}

'Scientific names were obtained by Dr. Nelson, Professor at the Universidad Nacional Autonoma de Honduras who identified plant samples from the research area. Additionally I used Foehlich and Schwerin 1983; House and Sanchez 1997; AFE-COHDETOR, BRP, MOPAWI, The Nature Conservancy, and USAID 2002; Fraser, Elizabeth 2003; Maconber, Ethan, Lauri Boxer-Macomber, and Arden Anderson; and TRAMIL Programe, Centroanerica/ ENDA CARIBE 2001. 


\begin{tabular}{|l|l|l|}
\hline Nance & Nance & Byrsomima crassifolia \\
\hline Naranja & Orange & Cimis sinensis \\
\hline Papas & Potato & Solanwm spp. \\
\hline Peras & & \\
\hline Pina & Pineapple & Ananas comosus \\
\hline Platano & Plantain & Musa spp. \\
\hline Ciruela & & Pmoms spp. \\
\hline Supa & & Bactris gasipaes \\
\hline Tamarindo & Iron wood & Dialium guianense \\
\hline Tomate & Tomato & Lycopersicon spp. \\
\hline Toronja & Grapefruit & Citnis maxima \\
\hline Yucca & Manioc & Manihot esculenta \\
\hline Zapote & Mamey & Pouferia mammosa \\
\hline
\end{tabular}




\section{APPENDIX E \\ LAS MARIAS ECO'TOURISM REGULATIONS \\ GUIDES ASSOCIATION RIO PLÁTANO BIOSPHERE RESERVE LAS MARIAS, GRACIAS A DIOS}

Formation: January 23, 1995

Objectives:

1. Unite the force of the community to solve tourism related problems.

2. Increase and share the income from tourism in an equitable manner with all the families of Las Marias.

3. Inprove the service provided by tourist guides to visitors to the Rio Plátano Biosphere Reserve.

\section{MEMBERSHIP REQUIREMENTS:}

- Permanent residents of the community

- Men of age (Graduated from clementary school).

- Single or widowed women

\section{POLITICAL STRUCTURE:}

1) The committee will function independently.

2) The committec will be directed by the President of the committee and the members of the Board of Directors.

3) The work of the "saca-guia" (the guide dispatcher) is completely separate from the Board of Directors, but members of the Board of Directors may serve as "saca-guias."

4) Only the Board of Directors can call a meeting of the General Assembly. 
5) The General Assembly will meet at least two times per year in order to elect "saca guias" and to provide a financial report.

6) Every July during the meeting of General Assembly, the prices of guide services will be revised.

7) Modifications to the regulations, norms or policies of the committee vill require an attendance of more than 70 percent of the active members and approval of 51 percent.

8) To implement any modification of the regulations, norms or policies, must be approved by 51 percent of the Board of Directors.

9) The modifications will be published and distributed through MOPAWI.

10) The Board of Directors can remove the position of any "saca-guia" with the vote of 50 percent plus one.

11) There exists the possibility of making the Guides Association subcommittee of the Tribal Council.

\section{ORGANIZATIONAL POLICIES}

\section{MANAGEMENT OF THE GUIDES LIST}

1) Each person interested in membership must meet the membership requisites in order to be on the guides list.

2) New members will be included on the list only through a formal request to the Tourism Committee and receiving their approval.

3) The list will be managed by "Saca-guias" in a rotation between members for trips up-river and walks in the forest.

4) A guide can travel with tourists only if it is their turn on the list. The individual preferences of the outside tour guide or the "saca-guia" do not matter.

5) If it is the guides turn on the list and they are in the community buyt unavailable to guide tourists, they have the right to guide the next available opportunity or they can designate another person to take their turn and in this vay fulfill their turn. 
6) The it is the guides turn on the list but they are not in the community and someone is not named to take their turn, they forfeit their turn.

\section{ROLE OF THE "SACA-GUIA"}

1) The three "saca-guias" will work by rotation which correspond to their zone.

a. Batiltuk-Centro

b. Centro-Pujulak

c. Pujulak-Bulebar

Each zone will have a "saca-guia" that lives in their zone and an assistant who will assume the responsibilities if the saca-guia is not in the community.

2) The "saca-guias" will work for a period of at least 3 months and no more than 6 nionths.

3) The "sacamguias" have the right to guide tourists only when their name appears on the list in the rotation. When the "saca-guia" is guiding tourists, he/she must entrust the list to another "saca-guia."

4) The "saca-guia" is responsible for registering the tourists in the visitors book and asking for a donation. The donations must be turned over to the treasurer of the Board of Directors.

5) Each "saca-guia" will receive monthly compensation paid out of this fund. Of each 10 Lempiras donated by tourists, 2 Lempiras will go to a special fund. During the second monthly meeting, the special fund will be divided by the three "saca-guias" with at least three inembers of the Board of the Directors. Each saca-guia will sign a receipt for the noney.

\section{ROLES OF GUIDES FROM OUTSIDE OF LAS MARIAS}

1) An outside guide does not have the right to appear on the list and such camnot occupy the place of a local guide.

2) An outside guide nust travel like a tourist and cannot lead a group into the forest without a local guide.

3) All outside guide must respect the opinion of the local guides with respect to the end of the work day.

\section{RESPONSIBILITIES OF THE "SACA-GUIAS"}

1) Present themselves to the tourists as soon as possible. 
2) Welcome the tourists and explain the guides organization, the norms and regulations of the community.

3) Ask the tourists to name a leader of their group.

4) Come to an agreement with the tourists about the length of their trip.

5) Explain the alternative routes, and explain the daily price schedule by boat per day including guides.

6) Explain that 20 Lempiras of the daily rate is to pay for the guides meals.

7) If they will be up-river for more than one night, ask if they would like to bring a cook or if they will be preparing their own meals.

8) If the tourists are going to hike in the forest, confirm that the guide on rotation knows the trails.

9) Before dispatching the guides, come to a final agreement on the total price of the trip.

10) Ensure that the guides have all the necessary equipment for the trip.

11) Remind the guides of the norms and regulations they must abide by during their trip and the consequences for not abiding by those rules.

12) Maintain sufficient copies of the guides list. 
NORMS AND REGULATIONS OF TOURISM IN LAS MARIAS RIO PLÁTANO BIOSPHERE RESERVE

\section{LOGISTICS:}

TRIPS UP RTVER

- 3 Guides per boat

- 2 Tourists per boat

HIKES IN THE FORESTS

- I Guide for groups of 5 or less tourists.

- 2 GUIDES for groups larger than 5 tourists.

Note: For trips of more than one day min of 2 guides.

\section{PRICES}

GUIDES

- 70 Lempiras per day (Monday-Saturday)

- 95 Lempiras per day (Sundays)

- 120 Lempiras per day holidays (Christmas, New Years, Good Friday)

Note: These prices include food for the guides

\section{BOAT RENTAL}

- 30 Lempiras per day

EXAMPLE

- Two tourists travel to the petroglyplis in a boat with three guides. Costs 240 Lempiras (three guides at 70 Lempiras per day $=120$ Lempiras, plus 30 Lempiras to rent the boat).

\section{VISITORS BOOK}

- The community is requesting a donation from tourists to be used for community projects. This is a voluntary donation. The saca-guia will ask for the donation with a green-orange book.

\section{TOURISM NORMS}

I) Elect a leader of the group to act as the voice of the group.

2) Arrange the total price of the trip prior to leaving with the guides.

3) Communicate to the saca guia any wonies your group might have prior to the trip. 
4) Respect the guides decision to set up camp for the night.

5) Respect the instructions of your guides about traveling in the dugout canoe.

6) Do not stray from your guides when you are hiking in the forest.

7) Cancel your bill upon arriving in Las Marias.

\section{TOURIST REGULATIONS}

1) The Rio Plátano Biosphere Reserve is a Wolrd Heritage Site declared by the United Nations in 1980. Because of this it is prohibited to take archaeoloigical relics, live animals or animal products (pets or skins) out of the reserve. All belong to the reserve.

2) The consumption of wildlife is for the subsistence of the local pcople. DO not eat animals in danger of extinction such as the Cuyamel, Great Currasow, Iguana or whatever other speicies.

3) Please ask permission before taking pictures of people and fulfill the obligation of sending copies via MOPAWI, LAS Marias, APDO 2175, Tegucigalpa, Honduras, C.A.

4) Respect the norms of the community with regards to alcohol and drugs. This is a dry and healthy community. If you violate these rules, the guides have the right to terminate the trip.

5) If you would like to fish, please practice catch and release.

\section{GUIDES NORMS}

1) Elect a leader of the guides group.

2) Explain how to ride in the dugout canoe.

3) Arrange the seats in the boat.

4) Look out for the security of the tourists on the river or in the forest.

5) Show and explain cultural and natural aspects of the reserve.

6) Explain all of the nomms which apply to tourists. 
7) Hunting is prohibited during trips up-river. If a guide kills an animal they will lose their next three turns. Guides may only take two fish per person.

8) Explain to the tourists the lack of infrastructure up-river.

9) Guides cannot travel with tourists if they are not in agreement with the regulations.

\section{GUIDES REGULATIONS}

1) Guiding tourists in not a hunting or fishing trip and thus it is prohibited to take arms, dogs, masks or hairpins.

2) For trips of a long duration, guides may take their gun for protection. 


\section{APPENDIX F \\ ECOTOURISM COMMITTEE OF BANAKA: REQUEST FOR MOPAWI \\ FUNDING}

Solicitud:

Nosotros el comité de Ecoturismo de Banaka, sloicitamos a la oficina de MOPAWI en Belén un apoyo que consiste en un Préstamo Financiero para la econstrución y funcionamiento de Hospedaje Túristico en la commidad de Banaka, para la compra de materials necesarios el Comité no cuenta conapoyo financiero y parar teminar este hospedaje y ponerlo en funcionamiento necesitamos comprar los siguientes materials:

1. Diez (10) Galones de gasoline

2. Tres (3) Galones de aciete No. 40

3. Does cuartos $(2 / 4)$ de aciete de 2 tiempas

4. Diez (10) libras de clavos de 3 pulgadas

5. Siete (7) libras de clavos de 4 pulgadas

6. Siete (7) libras de clavos de 5 pulgadas

7. Siete (7) libras de clavos de 2 pulgadas

8. Scis (6) colchones de 4 pulgadas

9. Seis (6) almohadas

10. Seis (6) Juegos de cameras

11. Seis (6) Platos seco de vidrio

12. Sies (6) Platos hondos de vidrio

13. Seis (6) Platos para sopa

14. Seis (6) Tazas para café

I5. Seis (6) Juegos de cubiertos

16. Scis (6) Vasos de vidrio

17. Dos (2) Lavamanos

18. Una (1) Cafetera

19. Una (1) Porrón

20. Una (1) Aztucarera

21. Dos (2) Cubetas Blancas de 5 galones

22. Un (1) Filtro para agua

23. Un (1) Salero

24. Dos (2) Cuchillos de cartor carnes \& verdures 
25. Un (1) Rayador de coco

26. Un (1) Telescopio

Esperando que esta solicitud se tome en cuenta en su próxima reunion,

Atentamente,

Lupario Martines, Presidente de Comité de Ecoturismo

Esther Gonzales, Servicios de Alimentacion y Hospedaje

Alex Osorno, Gúia de Visitantes

Jony Mejia, Servicios de Alinentacion

Noel Peter, Construcción y Transporte

Noe Nuñez, Tranporte de Materiales 